\title{
1.3 Розрахунок паль на дію поперечних навантажень
}

\subsection{1 Вигин палі в пружньому середовищі}

1.3.1.1. Застосування моделі Б.Н. Жемочкіна до розрахунку поперечно навантаженої палі при нелінійному розподілі жорсткості грунту по глибині занурення

Аналітичний метод розрахунку палі, зануреної в однорідну або багатошарову основу 3 нелінійним розподілом коефіцієнта жорсткості пов'язаний з великими математичними труднощами.

Як приклад розглянемо рішення при експоненційному розподілі коефіцієнта постелі уздовж осі палі (Мал. 1):

$$
C_{z}=C_{0} \cdot\left(1-e^{-\bar{a} \cdot z}\right)=C_{0} \cdot\left(1-e^{-a \cdot \bar{z}}\right),
$$

де $C_{z}$ - коефіцієнт постелі в даному перетині палі, тс/ ${ }^{3}$;

$C_{0}$ - деяка постійна величина коефіцієнта постелі на глибині $z \geq H, \mathrm{Tc} / \mathrm{m}^{3}$

$a$ - параметр, що характеризує швидкість наростання жорсткості основи, причому $a>0$;

$l$ - довжина заглибленої частини палі, м;

$z$ - відстань від поверхні грунту до даного перетину палі, м;

$\bar{z}$ - наведена (безрозмірна) глибина поперечного перерізу палі:

$$
\bar{a} \cdot z=\frac{a}{l} \cdot z=a \cdot \frac{z}{l}=a \cdot \bar{z} .
$$




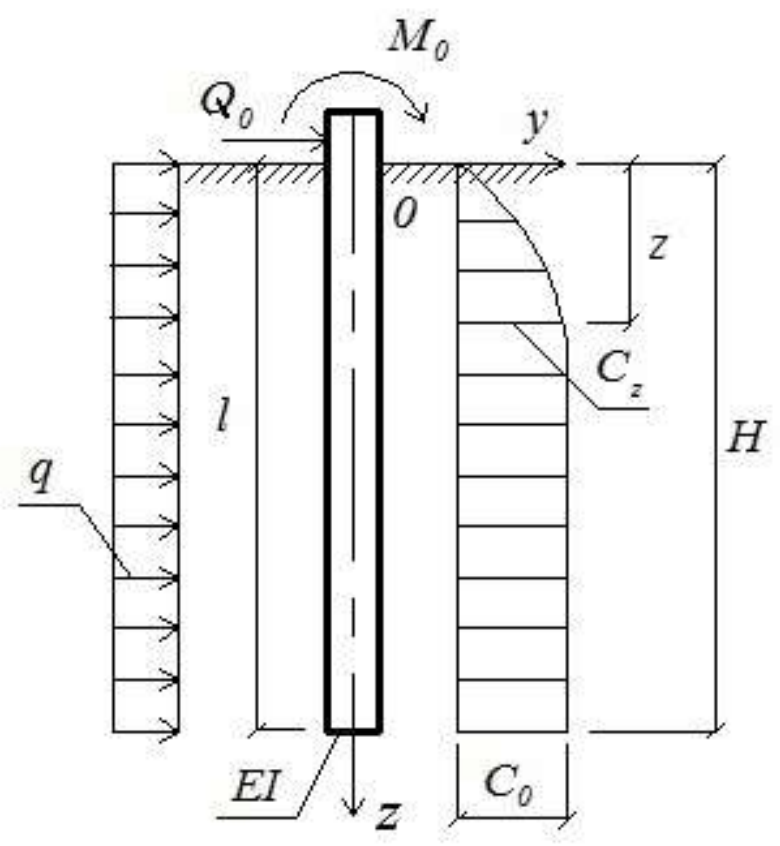

Малюнок 1. Розрахункова схема палі і епюра зміни коефіцієнта постелі

Диференціальне рівняння зігнутої осі палі при $C_{z}$, змінюється за законом (1), має вигляд:

$$
E I \cdot \frac{d^{4} y}{d z^{4}}+C_{0} \cdot\left(1-e^{-\bar{a} \cdot z}\right) \cdot y=0 .
$$

Запишемо (2) у вигляді:

$$
E I \cdot y^{I V}=C_{0} \cdot\left[e^{-\bar{a} \cdot z}-1\right] \cdot y .
$$

Диференціюючи за формулою Лейбніца рівняння (3) n раз, отримаємо наступне рекурентне співвідношення:

$$
\begin{aligned}
y^{(n)}= & (-1)^{n} \cdot u^{n-4} \cdot C_{0} \cdot e^{-\bar{a} \cdot z} \cdot y^{(0)} \cdot u_{n_{0}}+ \\
& +\sum_{i=0}^{n-5}(-1)^{n+i+1} \cdot\left(u_{n-1, i}+u_{n-1, n+1}\right) \cdot \bar{a}{ }^{n-5-i} \cdot C_{0} \cdot e^{-\bar{a} \cdot z} \cdot y^{(i+1)} \cdot \delta_{i}+ \\
& +C_{0} \cdot\left(e^{-\bar{a} \cdot z}-1\right) \cdot y^{(n-4)}
\end{aligned}
$$

де $u_{n i}$ - числовий коефіцієнт в $\mathrm{n}$ похідною, i-тий по порядку, при цьому $u_{n_{0}}=1$;

$\delta_{i}$ - безрозмірний коефіцієнт;

$$
\delta_{i}=1 \text { при } i=0 ; 1 \ldots n-6 ; \delta_{i}=0 \text { при } i=n-5 .
$$


Ця формула дає можливість послідовно обчислювати будь-яку похідну функції у (3), маючи в своєму розпорядженні значеннями величин при $\mathrm{z}=0$ :

$$
\left.\begin{array}{r}
y=y_{0} ; \\
y_{0}^{\prime}=\varphi_{0} ; \\
y_{0}^{\prime \prime}=\frac{M_{0}}{E I} ; \\
y_{0}^{\prime \prime \prime}=\frac{Q_{0}}{E I} ; \\
y_{0}^{(4)}=0 ;
\end{array}\right\}
$$

де $y_{0}, \varphi_{0}, M_{0}$ i $Q_{0}$ - відповідно прогин, кут повороту, згинальний момент i поперечна сила в 0-вої точці палі (Мал. 1).

Підставляючи значення похідних, визначених за формулами (4) i (5), в ряд Тейлора, отримуємо, приймаючи необхідні скорочення:

$$
\left.\begin{array}{c}
y_{z}=y_{0} \cdot A_{1}+\frac{\varphi_{0}}{\bar{a}} \cdot B_{1}+\frac{M_{0}}{\bar{a}^{2} \cdot E I} \cdot C_{1}+\frac{Q_{0}}{a^{-3} \cdot E I} \cdot D_{1}, \\
A_{1}=1+\gamma\left(-\frac{\bar{z}^{-5}}{5 !}+\frac{\bar{z}^{6}}{6 !}-\frac{\bar{z}^{7}}{7 !}+\frac{\bar{z}^{8}}{8 !}-\ldots\right)+\gamma^{2}\left(\frac{6 z^{-10}}{10 !}-\frac{28 z^{-11}}{11 !}+\frac{92 \bar{z}^{-12}}{12 !}-\ldots\right)+\ldots \\
B_{1}=\bar{z}+\gamma\left(-\frac{2 \bar{z}^{-6}}{6 !}+\frac{3 \bar{z}^{-7}}{7 !}-\frac{4 \bar{z}^{-8}}{8 !}+\ldots\right)+\gamma^{2}\left(\frac{2 z^{-11}}{11 !}-\frac{80 \bar{z}^{-12}}{12 !}+\frac{312 \cdot \bar{z}^{-13}}{13 !}-\ldots\right)+\ldots \\
C_{1}=\frac{\bar{z}^{2}}{2 !}+\gamma\left(-\frac{3 \bar{z}^{7}}{7 !}+\frac{6 z^{-8}}{8 !}-\frac{10 \bar{z}^{-9}}{9 !}+\ldots\right)+\gamma^{2}\left(\frac{24 z^{-12}}{12 !}-\frac{162 z^{-13}}{13 !}+\frac{730 z^{-14}}{14 !}-\ldots\right)+\ldots \\
D_{1}=\frac{\bar{z}^{3}}{3 !}+\gamma\left(-\frac{4 \bar{z}^{8}}{8 !}+\frac{10 \bar{z}^{-9}}{9 !}-\frac{20 z^{-10}}{10 !}+\ldots\right)+\gamma^{2}\left(\frac{36 z^{-13}}{13 !}-\frac{1280 z^{-14}}{14 !}+\frac{1430 z^{-15}}{15 !}-\ldots\right)+\ldots
\end{array}\right\},
$$

де

$$
\gamma=\frac{K \cdot b}{E I \cdot \bar{a}^{4}} .
$$

Диференціюючи послідовно рівняння (6), отримуємо остаточно: 


$$
\left.\begin{array}{c}
y_{\bar{z}}=y_{0} \cdot A_{1}^{\bar{z}}+\frac{\varphi_{0}}{\bar{a}} \cdot B_{1}{ }^{\bar{z}}+\frac{M_{0}}{\bar{a}^{2} \cdot E I} \cdot C_{1}^{\bar{z}}+\frac{Q_{0}}{\bar{a}^{3} \cdot E I} \cdot D_{1}^{\bar{z}} \\
\frac{\varphi_{\bar{z}}}{\bar{a}}=y_{0} \cdot A_{2}^{\bar{z}}+\frac{\varphi_{0}}{\bar{a}} \cdot B_{2}^{\bar{z}}+\frac{M_{0}}{\bar{a}^{2} \cdot E I} \cdot C_{2}^{\bar{z}}+\frac{Q_{0}}{\bar{a}^{3} \cdot E I} \cdot D_{2}^{\bar{z}} \\
\frac{M_{\bar{z}}}{\bar{a}^{2} \cdot E I}=y_{0} \cdot A_{3}^{\bar{z}}+\frac{\varphi_{0}}{\bar{a}} \cdot B_{3}^{\bar{z}}+\frac{M_{0}}{\bar{a}^{2} \cdot E I} \cdot C_{3}^{\bar{z}}+\frac{Q_{0}}{\bar{a}^{3} \cdot E I} \cdot D_{3}^{\bar{z}} \\
\frac{Q_{\bar{z}}}{\bar{a}^{3} \cdot E I}=y_{0} \cdot A_{4}{ }^{\bar{z}}+\frac{\varphi_{0}}{\bar{a}} \cdot B_{4}{ }^{\bar{z}}+\frac{M_{0}}{\bar{a}^{2} \cdot E I} \cdot C_{4}{ }^{\bar{z}}+\frac{Q_{0}}{\bar{a}^{3} \cdot E I} \cdot D_{4}{ }^{\bar{z}}
\end{array}\right\},
$$

де $y_{\bar{z}}, \varphi_{\bar{z}}, M_{\bar{z}}$ i $Q_{\bar{z}}$ - горизонтальне переміщення, кут повороту, згинальний момент і поперечна сила відповідно для довільного перетину з координатою $\bar{z}=\frac{z}{l}$

Значення функцій $A_{i}, B_{i}, C_{i}$ і $D_{i}$ при $\mathrm{i}=2 ; 3 ; 4$ отримуємо шляхом послідовного диференціювання $A_{1}, B_{1}, C_{1}$ i $D_{1}$.

Отримана система рівнянь (8) дозволяє вирішувати завдання з різними граничними умовами.

Розглядаючи рівняння (6) як ряд Тейлора, необхідно відзначити, що починаючи з якоїсь величини порядку многочлена n, при високих значеннях $\bar{z}$ ряд Тейлора «практично сходиться», що може спричинити за собою похибки в розрахунку. Математичний зміст цього визначення описаний Мишкіс А.Д.

Таким чином, найбільш проста і зручна в рішенні поставленого завдання виявляється схема Б.Н. Жемочкіна [40].

Порядок розрахунку полягає в наступному. палю довжиноюlрозбиваємо на рівні ділянки; в серединах яких ставимо жорсткі опорні стрижні, що забезпечують контакт палі з грунтом (Мал.2). Навантаження на підставу від кожного стержня приймається рівномірно розподіленим по площі $b \cdot \lambda$, де $b$ ширина палі і $\lambda$ - відстань між стрижнями.

При довільному розподілі коефіцієнта постелі по довжині палі в пружною стадії використовується змішаний метод вирішення (Мал. 2), при якому 
приймаються умови рівності нулю суми переміщень у напрямку кожного невідомого $X_{k}$ :

$$
X_{0} \cdot \delta_{k 0}+X_{1} \cdot \delta_{k 1}+X_{2} \cdot \delta_{k 2}+\ldots+X_{k} \cdot \delta_{k k}+\ldots+X_{n} \cdot \delta_{k n}-\omega_{0}-a_{K} \cdot \varphi_{0}+\Delta_{k p}=0 .
$$

Крім того, використовуються два рівняння рівноваги. Одне описує умову рівності нулю суми моментів всіх сил щодо точки 0, а друге - рівність нулю суми проекцій всіх сил на вісь, паралельну цим силам

$$
\left.\begin{array}{r}
X_{0}+X_{1}+X_{2}+\ldots+X_{k}+\ldots+X_{n}-\sum Q=0 \\
X_{0} \cdot a_{0}+X_{1} \cdot a_{1}+X_{2} \cdot a_{2}+\ldots+X_{k} \cdot a_{k}+\ldots+X_{n} \cdot a_{n}-\sum M=0 .
\end{array}\right\} .
$$

Поодинокі переміщення по напрямку $K$ від невідомих реактивних сил $X_{i}$ визначаються як сума деформації основи $V_{k}$ в точці $K$ і горизонтальних переміщень, викликаних вигином палі $\omega_{k i}$ :

$$
\left.\begin{array}{l}
\delta_{k i}=V_{k k}+w_{k i}, \quad(\text { при } k=i) ; \\
\delta_{k i}=w_{k i}, \quad(\text { при } k \neq i),
\end{array}\right\},
$$

де $w_{k i}$ - функції Б.Н. Жемочкіна [40], рівні

$$
w_{k i}=\frac{\lambda^{3}}{6 \cdot E I} \cdot \overline{\omega_{k i}},
$$

де $\overline{\omega_{k i}}$ - поодинокі деформації палі в точці К від сили $X_{k}$, затабульовані в і рівні

$$
\overline{\omega_{k i}}=\left(\frac{a_{k}}{\lambda}\right)^{2} \cdot\left(3 \cdot \frac{a_{i}}{\lambda}-\frac{a_{k}}{\lambda}\right)
$$

де $\lambda$ - крок опорних стрижнів, м;

$a_{i}$ - відстань від умовного защемлення до стрижня $i, \mathrm{M}$.

Осадка основи в точці $K$ викликана тільки реактивної силою $X_{k}$, а тому одиничне переміщення постелі $\overline{V_{k k}}$ дорівнює

$$
\overline{V_{k k}}=\frac{1}{\lambda \cdot b \cdot C_{k}},
$$

де $b$ - ширина перерізу палі (балки), м;

$C_{k}$ - коефіцієнт жорсткості в точці $K$, Тс / м3. 
Тому першу рівність (11) можна записати у вигляді

$$
\delta_{k k}=\frac{\lambda^{3}}{6 \cdot E I} \cdot\left(\gamma_{k}+\overline{\omega_{k k}}\right),
$$

де

$$
\gamma_{k}=\frac{6 \cdot E I}{b \cdot C_{k} \cdot \lambda^{4}}
$$

Вантажні переміщення від зовнішніх сил представимо у вигляді

$$
\Delta_{k p}=\frac{\lambda^{3}}{6 \cdot E I} \cdot Q_{0} \cdot \overline{w_{k i}} \cdot
$$

Тоді система канонічних рівнянь запишеться в такий спосіб

$$
A \cdot\left|\begin{array}{c}
X_{0} \\
X_{1} \\
\cdots \\
X_{n} \\
\omega_{0} \\
\varphi_{0}^{\prime}
\end{array}\right|=\left|\begin{array}{c}
-\Delta_{0 p} \\
-\Delta_{1 p} \\
\cdots \\
-\Delta_{n p} \\
\sum Q \\
\sum M / \lambda
\end{array}\right|
$$

де А - квадратна матриця:

$$
A=\left|\begin{array}{cccccc}
\delta_{00} & \delta_{01} & \ldots & \delta_{0 n} & 1 & a_{0} \\
\delta_{11} & \delta_{12} & \ldots & \delta_{1 n} & 1 & a_{1} \\
\ldots & \ldots & \ldots & \ldots & \ldots & \ldots \\
\delta_{n 0} & \delta_{n 1} & \ldots & \delta_{n n} & 1 & a_{n} \\
1 & 1 & \ldots & 1 & 0 & 0 \\
a_{0} & a_{1} & \ldots & a_{n} & 0 & 0
\end{array}\right|,
$$

відзначимо, що отримуються з рішення системи (19) значення $\omega_{0}$ і $\varphi_{0}^{\prime}$ збільшені в $\frac{6 \cdot E I}{\lambda^{3}}$ раз.

\subsubsection{1. Комплексна розрахункова модель №1}

Запишемо закономірність зміни коефіцієнта постелі уздовж осі палі наступним чином (Мал. 2): 


$$
C_{z}=C_{n}+C_{0} \cdot\left(\frac{z}{l}\right)^{\alpha},
$$

де $C_{n}$ - коефіцієнт постелі (жорсткості) на рівні поверхні грунту, тс $/ \mathrm{M}^{3}$;

$C_{0}$ - коефіцієнт постелі на глибині $1, \mathrm{Tc} / \mathrm{M}^{3}$;

$C_{z}$ - коефіцієнт постелі на довільній глибині $z, \mathrm{Tc} / \mathrm{M}^{3}$;

$\alpha$ - розрахунковий параметр, що характеризує пружно-пластичні властивості грунту, причому $a>0$;

$l$ - довжина заглибленої частини палі, м;

$z$ - відстань від поверхні грунту до даного перетину палі, м.

Вираз (20) можна записати у вигляді

$$
C_{z}=C_{0} \cdot\left[\frac{C_{n}}{C_{0}}+\left(\frac{z}{l}\right)^{\alpha}\right] .
$$

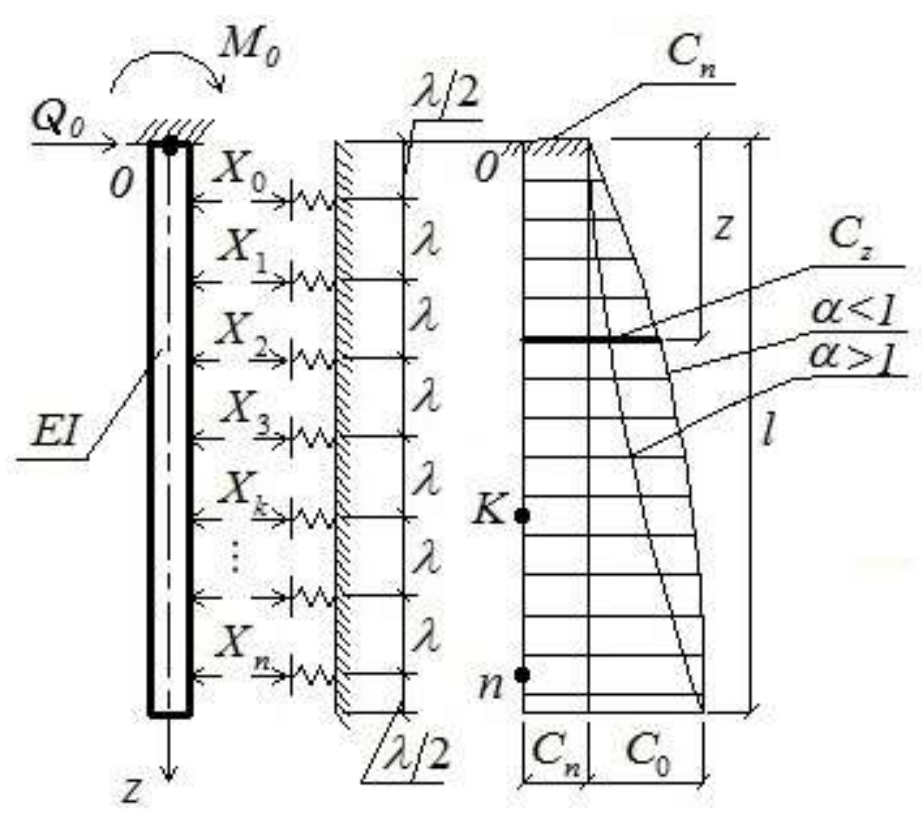

Малюнок 2. Основна система і епюра коефіцієнта постелі $C_{z}$ комплексної моделі № 1

Прийнявши такі позначення

$$
\frac{C_{n}}{C_{0}}=\overline{C_{n}} ; \quad \frac{z}{l}=\bar{z} ; \quad \lambda=\frac{l}{n},
$$


запишемо за методом Б.М. Жемочкіна поодинокі переміщення по напрямку До від невідомих реактивних сил $X_{i}$, Які визначаються як сума опади підстави $V_{k}$ в точці $K$ і переміщень (прогинів), викликаних вигином палі $\omega_{k k}, 3$ урахуванням розрахункової ширини $b_{p}$

$$
\delta_{k k}=\frac{\lambda^{3}}{6 \cdot E I} \cdot \overline{\omega_{k k}}+\frac{1}{\lambda \cdot b_{p} \cdot C_{0} \cdot\left(\overline{C_{n}}+\overline{z_{k}^{\alpha}}\right)},
$$

що приводиться до вигляду

$$
\delta_{k k}=\frac{\lambda^{3}}{6 \cdot E I} \cdot\left[\overline{\omega_{k k}}+\frac{6 \cdot E I}{\lambda^{4} \cdot b_{p} \cdot C_{0} \cdot\left(\overline{C_{n}}+\overline{z_{k}^{\alpha}}\right)}\right] .
$$

Запишемо другий член виразу (23)

$$
\frac{6 \cdot E I}{\lambda^{4} \cdot b_{p} \cdot C_{0} \cdot\left(\overline{C_{n}}+\overline{z_{k}^{\alpha}}\right)}=\frac{6}{\lambda^{4} \cdot \beta_{\text {д }}^{4}} \cdot \overline{\overline{C_{n}}+\overline{z_{k}^{\alpha}}},
$$

де

$$
\begin{aligned}
& \beta_{\text {д }}=\sqrt[4]{\frac{C_{0} \cdot b_{p}}{E I}} ; . \\
& \overline{z_{k}^{\alpha}}=\left(\frac{z}{l}\right)^{\alpha}=\left(\frac{k \cdot \lambda}{n \cdot \lambda}\right)^{\alpha}=\left(\frac{k}{n}\right)^{\alpha} ; \\
& \overline{l_{\beta}}=l \cdot \beta_{\text {д }} .
\end{aligned}
$$

3 (24), з урахуванням (25), (26), (27), знайдемо

$$
\frac{6}{\lambda^{4} \cdot \beta_{\text {д }}^{4} \cdot\left(\overline{C_{n}}+\overline{z_{k}^{\alpha}}\right)}=\frac{6 \cdot n^{4}}{l^{4} \cdot \beta_{\text {д }}^{4}} \cdot \frac{n^{\alpha}}{\overline{C_{n}} \cdot n^{\alpha}+k^{\alpha}}=\frac{6 \cdot n^{(4+\alpha)}}{\overline{l_{\beta}^{4}} \cdot\left(\overline{C_{n}} \cdot n^{\alpha}+k^{\alpha}\right)} .
$$

отже

$$
\delta_{k k}=\frac{\lambda^{3}}{6 \cdot E I} \cdot\left[\overline{\omega_{k k}}+\frac{6 \cdot n^{(4+\alpha)}}{\overline{l_{\beta}^{4}} \cdot\left(\overline{C_{n}} \cdot n^{\alpha}+k^{\alpha}\right)}\right],
$$

або 


$$
\delta_{k k}=\frac{\lambda^{3}}{6 \cdot E I} \cdot\left[\overline{\omega_{k k}}+\frac{6 \cdot n^{4}}{\overline{l_{\beta}^{4}} \cdot\left(\overline{C_{n}}+\left(\frac{k}{n}\right)^{\alpha}\right)}\right] \text {. }
$$

3 отриманих залежностей для комплексної моделі № 1 отримаємо рішення для деяких моделей основи.

1.1.1.А. Для статичної епюри зміни коефіцієнта постелі рішення отримаємо при $\overline{C_{n}}=0$ з (30) (Мал. 3):

$$
\delta_{k k}=\frac{\lambda^{3}}{6 \cdot E I} \cdot\left[\overline{\omega_{k k}}+\frac{6 \cdot n^{4}}{\overline{l_{\beta}^{4}} \cdot\left(\frac{k}{n}\right)^{\alpha}}\right] .
$$

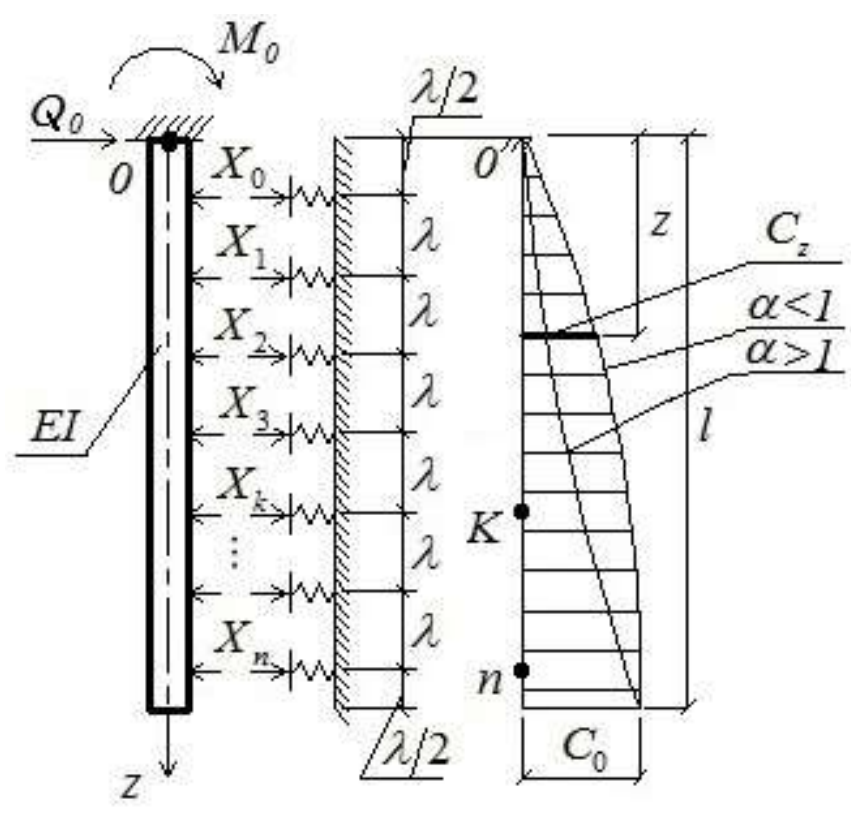

Малюнок 3. Основна система і епюра статичного розподілу коефіцієнта постелі

1.1.1.Б. Лінійно зростаюча (трикутна) епюра коефіцієнта постелі (Мал. 4). Рішення отримаємо при $\overline{C_{n}}=0 ; \alpha=1$ з (29) або (30) 


$$
\delta_{k k}=\frac{\lambda^{3}}{6 \cdot E I} \cdot\left[\overline{\omega_{k k}}+\frac{6 \cdot n^{5}}{\overline{l_{\beta}^{4}} \cdot k}\right]
$$

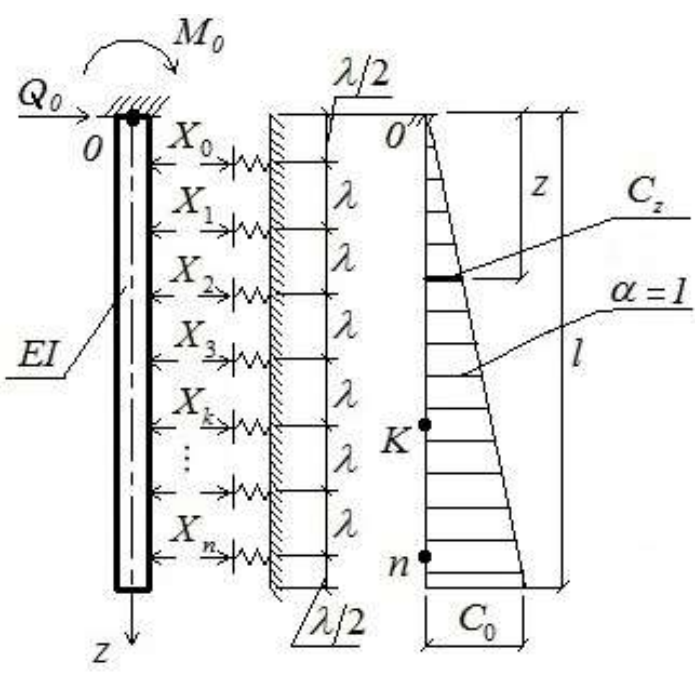

Малюнок 4. Основна система і трикутна епюра коефіцієнта постелі

1.1.1.В. Рішення при трапецеїдальній закономірності розподілу коефіцієнта постелі (Мал. 5) отримаємо з (29) при $\alpha=1$.

$$
\delta_{k k}=\frac{\lambda^{3}}{6 \cdot E I} \cdot\left[\overline{\omega_{k k}}+\frac{6 \cdot n^{5}}{\overline{l_{\beta}^{4}} \cdot\left(\overline{C_{n}} \cdot n+k\right)}\right] .
$$

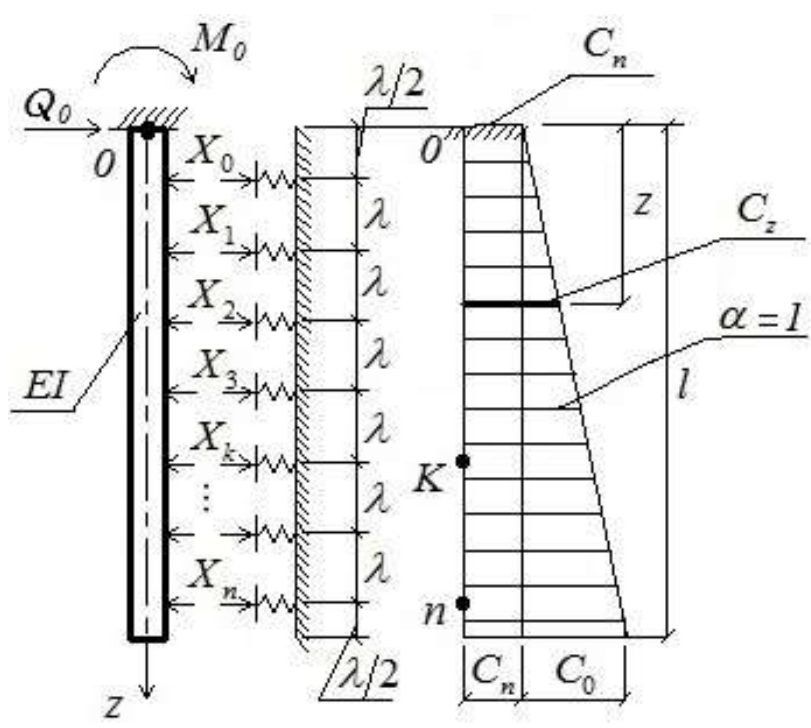

Малюнок 5. Основна система і трапецеїдальних епюра коефіцієнта постелі 


\section{Приклад розрахунку 1}

Розглянемо горизонтально завантажену палю, занурену в основу, що характеризується трапецеїдальним коефіцієнтом жорсткості, за пропонованою методикою і використовуючи рішення А.С. Маліева. Вихідні дані: паля 3 характеристиками $\mathrm{EI}=1 \cdot 105 \mathrm{Tc} \cdot \mathrm{m} 2 ; \mathrm{b}=0.96 \mathrm{~m} ; l=10 \mathrm{M}$. Грунт характеризується

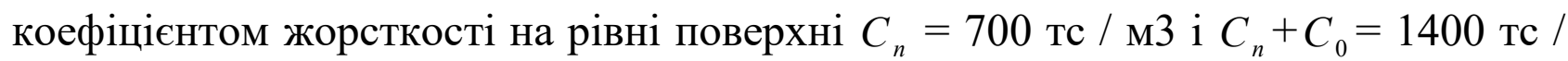
м3 на глибині 1. Горизонтальна сила $\mathrm{Q}=2$ тс прикладена у поверхні грунту.

Графіки значень $y_{z}, M_{z}$ i $\sigma_{z}$ в залежності від z для палі представлені на Мал. 6. Як бачимо, результати розрахунку добре узгоджуються з відповідними значеннями, отриманими за методом А.С. Маліева [42].

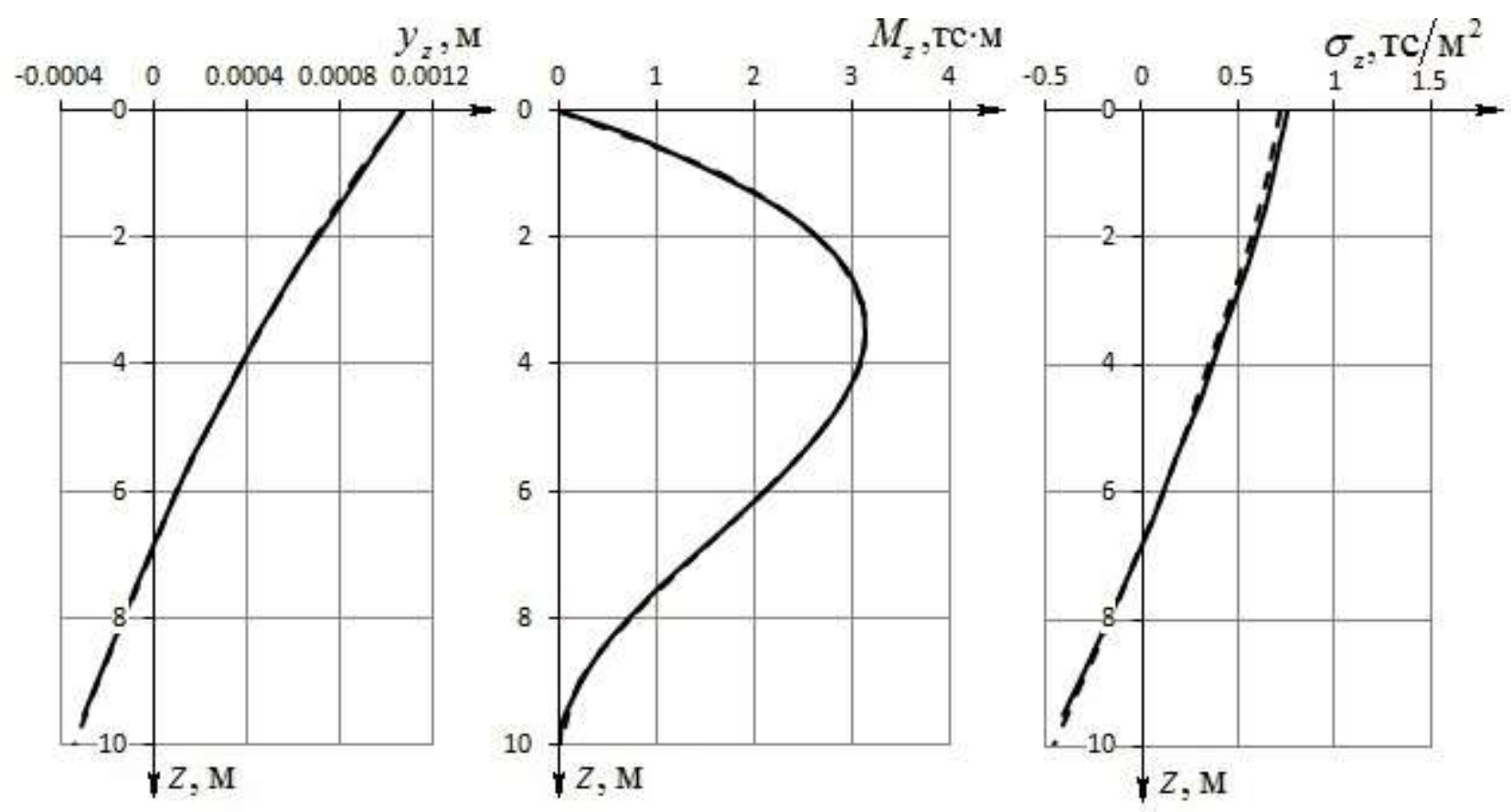

Малюнок 6. Епюри $y_{z}, M_{z}$ i $\sigma_{z}$ приклад розрахунку 1 (суцільна лінія запропонована методика; пунктирна лінія - розв'язок А.С. Малієва)

\subsubsection{2 Комплексна розрахункова модель № 2}

Запишемо закономірність зміни коефіцієнта постелі уздовж осі палі наступним чином (Мал. 7):

$$
C_{z}=C_{n}+C_{0} \cdot\left(1-e^{-\bar{a} \cdot z}\right)=C_{n}+C_{0} \cdot\left(1-e^{-a \cdot \bar{z}}\right),
$$

де $C_{z}$ - коефіцієнт постелі на довільній глибині $z$, тс $/ \mathrm{m}^{3}$; 
$C_{n}$ - коефіцієнт постелі на рівні поверхні грунту, тс $/ \mathrm{M}^{3}$;

$C_{0}$ - деяка постійна величина коефіцієнта постелі на глибині $\mathrm{H}, \mathrm{Tc} / \mathrm{m}^{3}$;

$a$ - параметр, що залежить від переміщень палі і характеризує ступінь розвитку пластичних деформацій в грунті, причому $a>0$;

$l$ - довжина заглибленої частини палі, м;

$z$ - відстань від поверхні грунту до даного перетину палі, м;

$\bar{z}$ - наведена (безрозмірна) глибина поперечного перерізу палі.

Вираз (34) можна записати у вигляді

$$
C_{z}=C_{0} \cdot\left[\frac{C_{n}}{C_{0}}+\left(1-e^{-a \cdot \bar{z}}\right)\right] .
$$

позначимо

$$
\frac{C_{n}}{C_{0}}=\overline{C_{n}} ; \quad \frac{z}{l}=\bar{z} ; \quad \lambda=\frac{l}{n} .
$$

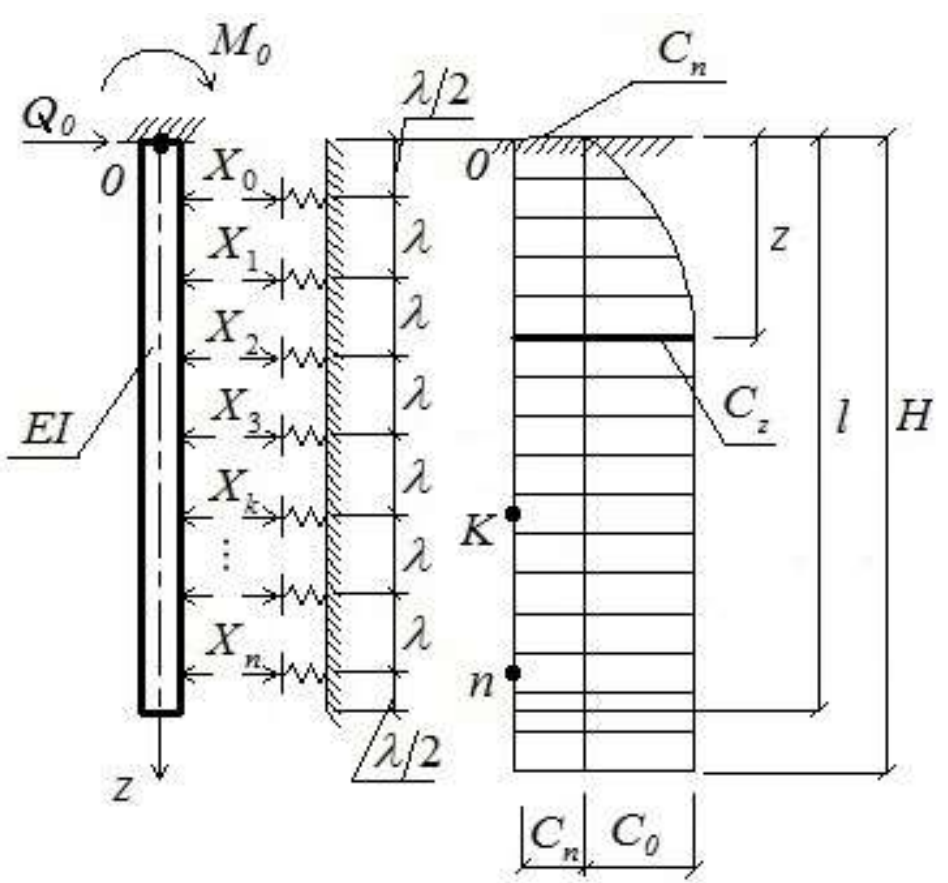

Малюнок 7. Основна система і епюра коефіцієнта постелі $C_{z}$ комплексної моделі № 2 
Запишемо за методом Б.М. Жемочкіна поодинокі переміщення

$$
\delta_{k k}=\frac{\lambda^{3}}{6 \cdot E I} \cdot \overline{\omega_{k k}}+\frac{1}{\lambda \cdot b_{p} \cdot C_{0} \cdot\left[\overline{C_{n}}+\left(1-e^{-a \cdot \bar{z}}\right)\right]},
$$

що можна привести до вигляду

$$
\left.\delta_{k k}=\frac{\lambda^{3}}{6 \cdot E I} \cdot\left[\overline{\omega_{k k}}+\frac{6 \cdot E I}{\lambda^{4} \cdot b_{p} \cdot C_{0} \cdot\left[\overline{C_{n}}+\left(1-e^{-a \cdot \bar{z}}\right)\right.}\right]\right] .
$$

позначивши

$$
\mu_{\text {д }}=\frac{1}{\lambda} \cdot \sqrt[4]{\frac{6 \cdot E I}{b_{p} \cdot C_{0}}},
$$

запишемо другий член виразу (37) з урахуванням умов (35)

$$
\frac{6 \cdot E I}{\lambda^{4} \cdot b_{p} \cdot C_{0} \cdot\left[\overline{C_{n}}+\left(1-e^{-a \cdot \bar{z}}\right)\right]}=\mu_{\text {д }}^{4} \cdot \frac{1}{\left[\overline{C_{n}}+1-e^{-a \cdot \frac{k}{n}}\right]} .
$$

1.1.А. Експоненціальне розподіл коефіцієнта постелі моделі № 2 при $\overline{C_{n}}=0$ (Мал. 8)

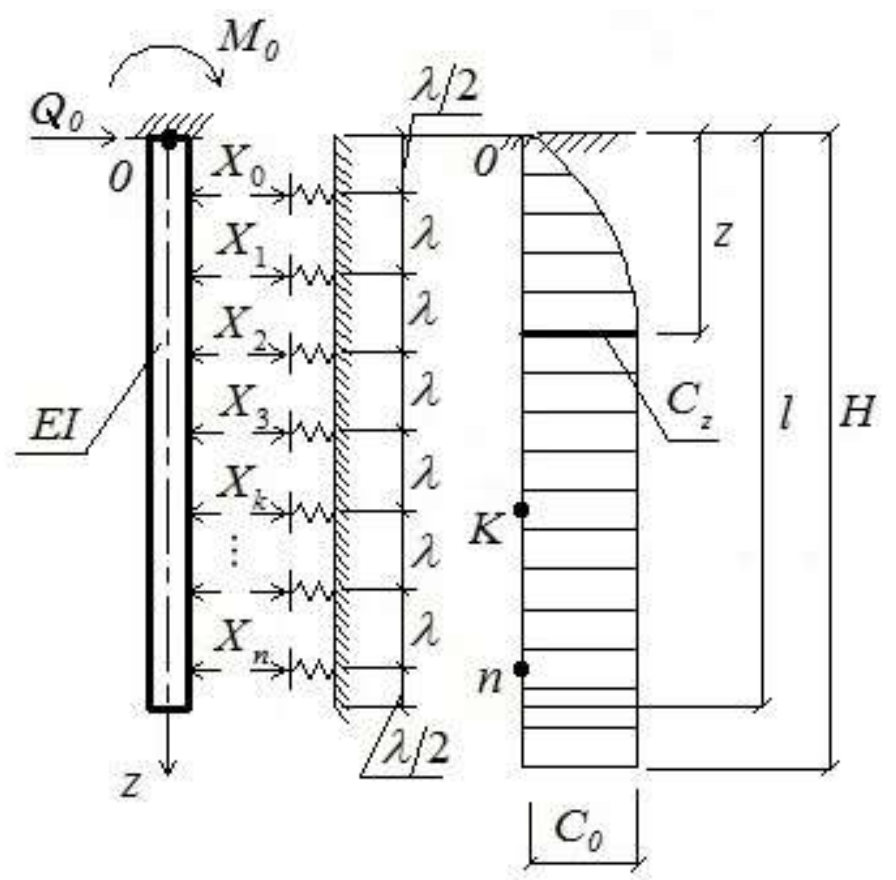

Малюнок 8. Основна система і експоненціальна епюра коефіцієнта постелі моделі № 2 при $\overline{C_{n}}=0$ 
Рішення отримаємо 3 (38) при $C_{n}=0$ в загальному вигляді

$$
\delta_{k k}=\frac{\lambda^{3}}{6 \cdot E I} \cdot\left[\overline{\omega_{k k}}+\frac{\mu_{\text {д }}^{4}}{\left[1-e^{-\frac{a \cdot k}{10}}\right]}\right] .
$$

1.1.3. Комплексна розрахункова модель № 3

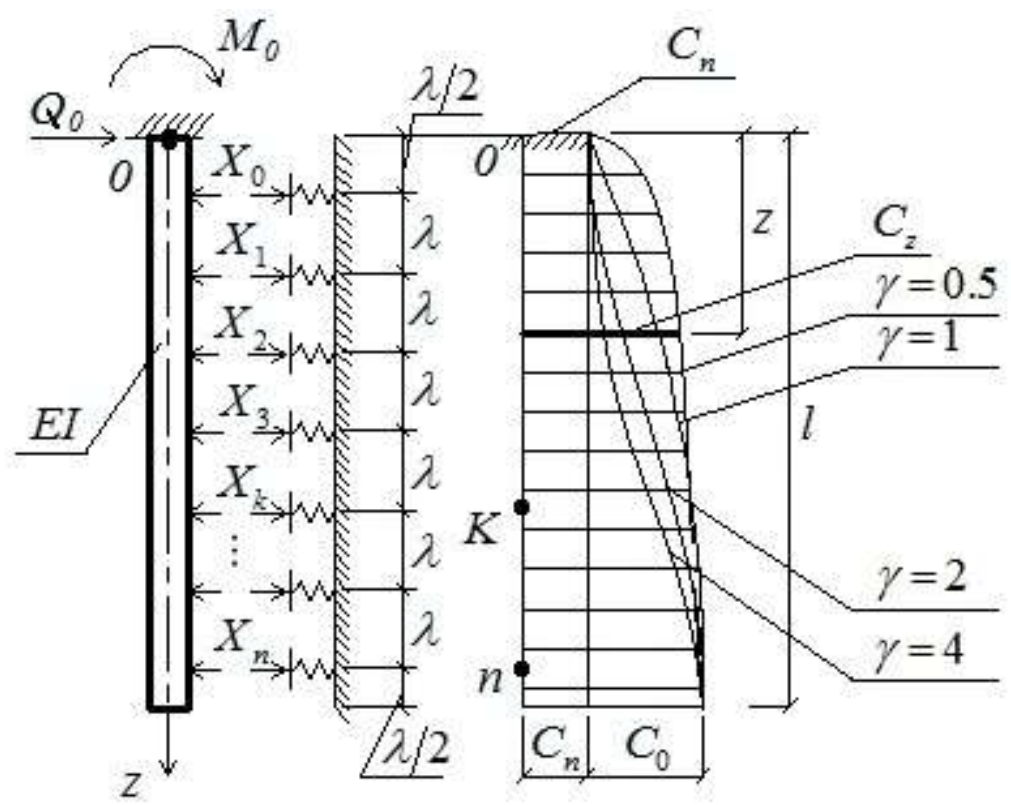

Малюнок 9. Основна система і епюра коефіцієнта постелі $C_{z}$ комплексної моделі № 3

Запишемо закономірність зміни коефіцієнта постелі уздовж осі палі наступним чином (Мал. 9):

$$
C_{z}=C_{n}+C_{0} \cdot\left\{\sin \left[\frac{\pi}{2} \cdot\left(\frac{z}{l}\right)^{\gamma}\right]\right\}=C_{n}+C_{0} \cdot\left[\sin \left(\frac{\pi}{2} \cdot \frac{-\gamma}{z^{\gamma}}\right)\right],
$$

де $C_{n}$ - коефіцієнт постелі (жорсткості) на рівні поверхні грунту, тс $/ \mathrm{m}^{3}$;

$C_{0}$ - коефіцієнт постелі на глибині $1, \mathrm{Tc} / \mathrm{m}^{3}$; 
$C_{z}$ - коефіцієнт постелі на довільній глибині $z, \mathrm{Tc} / \mathrm{m}^{3}$;

$\gamma$ - розрахунковий параметр, що характеризує пружно-пластичні властивості грунту, причому $\gamma>0$;

$l$ - довжина заглибленої частини палі, м;

$z$ - відстань від поверхні грунту до даного перетину палі, м.

$\bar{z}$ - наведена (безрозмірна) глибина поперечного перерізу палі,

$$
\bar{a} \cdot z=\frac{a}{l} \cdot z=a \cdot \frac{z}{l}=a \cdot \bar{z} .
$$

Вираз (40) можна записати вигляді

$$
C_{z}=C_{0} \cdot\left\{\frac{C_{n}}{C_{0}}+\sin \left[\frac{\pi}{2} \cdot\left(\frac{z}{l}\right)^{\gamma}\right]\right\},
$$

3 урахуванням позначень (35), запишемо за методом Б.М. Жемочкіна поодинокі переміщення

$$
\delta_{k k}=\frac{\lambda^{3}}{6 \cdot E I} \cdot \overline{\omega_{k k}}+\frac{1}{\lambda \cdot b_{p} \cdot C_{0} \cdot\left[\overline{C_{n}}+\sin \left(\frac{\pi}{2} \cdot z\right)\right]},
$$

що можна привести до вигляду

$$
\left.\delta_{k k}=\frac{\lambda^{3}}{6 \cdot E I} \cdot\left[\overline{\omega_{k k}}+\frac{6 \cdot E I}{\lambda^{4} \cdot b_{p} \cdot C_{0} \cdot\left[\overline{C_{n}}+\sin \left(\frac{\pi}{2} \cdot \bar{z}\right)\right.}\right]\right] .
$$

позначивши

$$
\begin{gathered}
\eta_{\text {д }}=\sqrt[4]{\frac{b_{p} \cdot C_{0}}{E I}}, \\
\bar{z}^{\gamma}=\left(\frac{z}{l}\right)^{\gamma}=\left(\frac{k \cdot \lambda}{n \cdot \lambda}\right)^{\gamma}=\left(\frac{k}{n}\right)^{\gamma} ; \\
\overline{l_{\eta}}=l \cdot \eta_{\text {д }} .
\end{gathered}
$$

запишемо другий член виразу (42) з урахуванням умов (35) 


$$
\frac{6 \cdot E I}{\lambda^{4} \cdot b_{p} \cdot C_{0} \cdot\left[\overline{C_{n}}+\sin \left(\frac{\pi}{2} \cdot z^{\gamma}\right)\right]}=\frac{6}{\lambda^{4} \cdot \eta_{\text {д }}^{4} \cdot\left[\overline{C_{n}}+\sin \left(\frac{\pi}{2} \cdot \frac{-\gamma}{z}\right)\right]}=\frac{6 \cdot n^{4}}{\bar{l}_{\eta}^{4} \cdot\left\{\overline{C_{n}}+\sin \left[\frac{\pi}{2} \cdot\left(\frac{k}{n}\right)^{\gamma}\right]\right\}}
$$

Підставивши (43) в (42), отримаємо

$$
\delta_{k k}=\frac{\lambda^{3}}{6 \cdot E I} \cdot\left[\overline{\omega_{k k}}+\frac{6 \cdot n^{4}}{\bar{l}_{\eta}^{4} \cdot\left\{\overline{C_{n}}+\sin \left[\frac{\pi}{2} \cdot\left(\frac{k}{n}\right)^{\gamma}\right]\right\}}\right] .
$$

при $n=10$ знайдемо

$$
\delta_{k k}=\frac{\lambda^{3}}{6 \cdot E I} \cdot\left[\overline{\omega_{k k}}+\frac{6 \cdot 10^{4}}{\bar{l}_{\eta}^{4} \cdot\left\{\overline{C_{n}}+\sin \left[\frac{\pi}{2} \cdot\left(\frac{k}{10}\right)^{\gamma}\right]\right\}}\right]
$$

1.1.3.А. При синусоїдальної закономірності коефіцієнта постелі рішення отримаємо при $\overline{C_{n}}=0$ з (44) (Мал. 10).

$$
\begin{aligned}
& \delta_{k k}=\frac{\lambda^{3}}{6 \cdot E I} \cdot\left[\frac{6 \cdot n^{4}}{\omega_{k k}}+\frac{{ }^{4} \cdot \sin \left[\frac{\pi}{2} \cdot\left(\frac{k}{n}\right)^{\gamma}\right]}{.}\right. \\
& \text { Q }
\end{aligned}
$$

Малюнок 10. Основна система і епюра синусоїдального розподілу коефіцієнта постелі 
1.3.1.1.4. Комплексна розрахункова модель № 4 (трапецієподібний розподіл коефіцієнта постелі)

Закономірність зміни коефіцієнта постелі уздовж осі палі запишемо наступним чином (Мал. 11):

$$
C_{z}=C_{n}+m \cdot z
$$

де $C_{z}$ - коефіцієнт постелі на довільній глибині $z$, тс $/ \mathrm{m}^{3}$;

$C_{n}$ - коефіцієнт постелі на рівні поверхні грунту, тс $/ \mathrm{m}^{3}$;

$m=\operatorname{tg} \varphi$ - тангенс кута нахилу епюри коефіцієнта постелі (коефіцієнт пропорційності), тс $/ \mathrm{M}^{4}$;

$z$ - відстань від поверхні грунту до даного перетину палі, м.

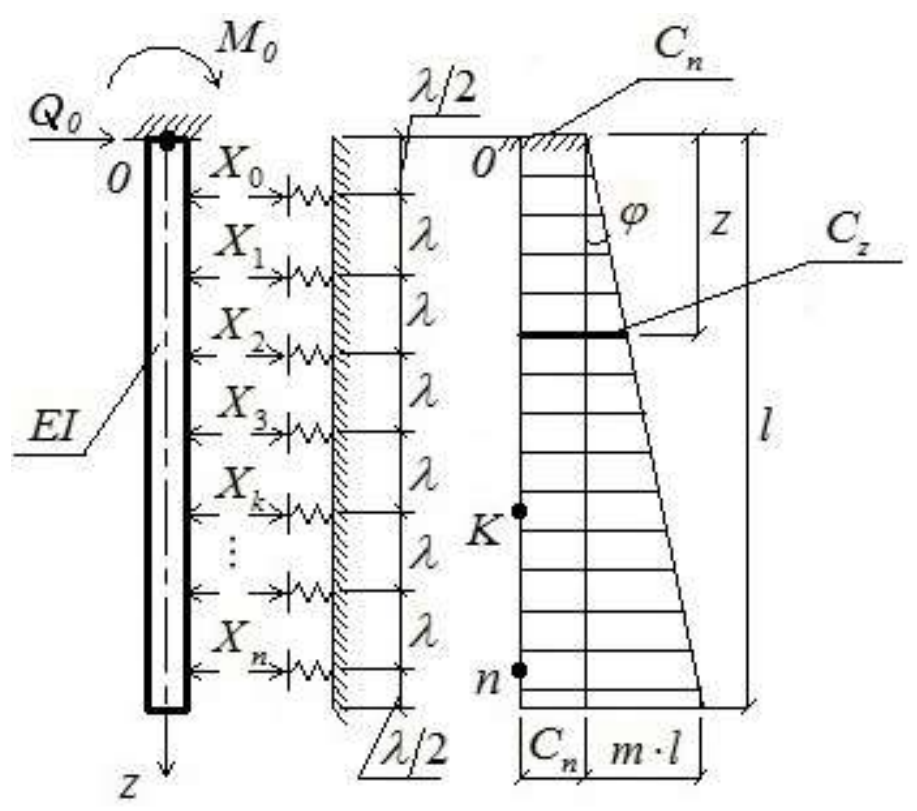

Малюнок 11. Основна система і епюра коефіцієнта постелі $C_{z}$ комплексної моделі № 4

Запишемо за методом Б.М. Жемочкіна поодинокі переміщення

$$
\delta_{k k}=\frac{\lambda^{3}}{6 \cdot E I} \cdot\left[\overline{\omega_{k k}}+\frac{6 \cdot E I}{\lambda^{4} \cdot b_{p} \cdot m \cdot\left(\frac{C_{n}}{m}+z\right)}\right] .
$$

Другий член формули (48) приводимо до виду 


$$
\frac{6 \cdot E I}{\lambda^{4} \cdot b_{p} \cdot C_{0} \cdot\left(C_{n}+z\right)}=\frac{6 \cdot E I}{\lambda^{5} \cdot b_{p} \cdot m} \cdot \frac{1}{\frac{C_{n}}{m \cdot \lambda}+\frac{z}{\lambda}}
$$

де

$$
\begin{aligned}
& \frac{z}{l}=\frac{k \cdot \lambda}{n \cdot \lambda}=\frac{k}{n} ; \\
& \frac{C_{n}}{m \cdot \lambda}=\frac{C_{n} \cdot n}{m \cdot l} ; \\
& \alpha_{\text {д }}=\sqrt[5]{\frac{m \cdot b_{p}}{E I}} .
\end{aligned}
$$

Так як $\overline{l_{\alpha}}=l \cdot \alpha_{\text {д }}$, то формулу (49) запишемо у вигляді

$$
\frac{6 \cdot E I}{\lambda^{5} \cdot b_{p} \cdot m} \cdot \frac{1}{\frac{C_{n}}{m \cdot \lambda}+\frac{z}{\lambda}}=\frac{6 \cdot n^{5}}{\left(l \cdot \alpha_{\text {д }}\right)^{5}} \cdot \frac{1}{\frac{C_{n}}{m \cdot \lambda}+\frac{z}{\lambda}}=\frac{6 \cdot n^{5}}{\overline{l_{\alpha}^{5}}} \cdot \frac{1}{\frac{C_{n} \cdot n}{m \cdot l}+k} .
$$

Підставивши (51) в (48) і при $n=10$ отримаємо

$$
\delta_{k k}=\frac{\lambda^{3}}{6 \cdot E I} \cdot\left[\overline{\omega_{k k}}+\frac{6 \cdot 10^{5}}{\overline{l_{\alpha}^{5}} \cdot\left(\frac{10 \cdot C_{n}}{m \cdot l}+k\right)}\right]
$$

Можна довести, що $l^{4} \cdot \beta_{\text {д }}^{4}=l^{5} \cdot \alpha_{\text {д }}^{5}$ :

$$
\begin{aligned}
l^{4} \cdot \frac{C_{0}}{E I} & =l^{5} \cdot \frac{m}{E I} \\
l^{4} \cdot \frac{m \cdot l}{E I} & =l^{5} \cdot \frac{m}{E I} .
\end{aligned}
$$

1.1.4.А. Трикутний розподіл коефіцієнта постелі (Мал. 12)

Рішення отримаємо з (52) при $C_{n}=0$ в загальному вигляді

$$
\delta_{k k}=\frac{\lambda^{3}}{6 \cdot E I} \cdot\left[\overline{\omega_{k k}}+\frac{6 \cdot 10^{5}}{\overline{l_{\alpha}^{5}} \cdot k}\right]
$$

Покажемо, що з рішення (48) для комплексної моделі № 4 при $C_{n}=0$ для трикутного розподілу коефіцієнта постелі отримаємо 


$$
\delta_{k k}=\frac{\lambda^{3}}{6 \cdot E I} \cdot\left[\overline{\omega_{k k}}+\frac{6 \cdot 10^{5}}{\overline{l_{\alpha}^{5}} \cdot k}\right] .
$$

А так як $\overline{l_{\beta}^{4}}=\overline{l_{\alpha}^{5}}$, То рівності (53) i (54) збігаються.

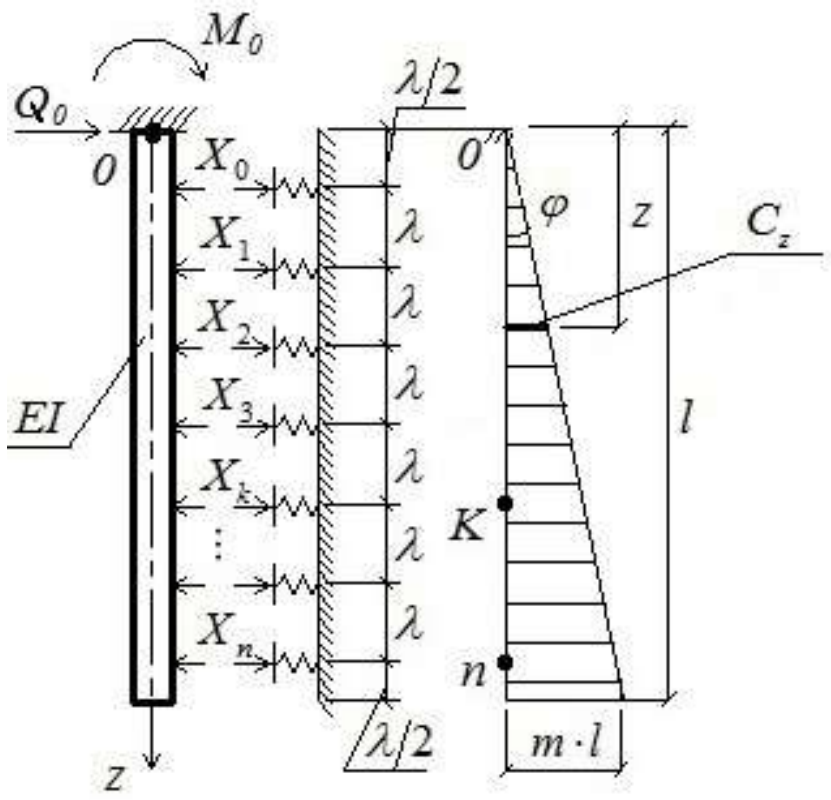

Малюнок 12 Основна система і трикутна епюра коефіцієнта постелі

1.1.4.Б. Модель Вінклера з постійним коефіцієнтом постелі (Мал.13)

3 (52) при $m=0$ отримаємо

$$
\delta_{k k}=\frac{\lambda^{3}}{6 \cdot E I} \cdot\left[\overline{\omega_{k k}}+\frac{6 \cdot E I}{\lambda^{4} \cdot b_{p} \cdot C_{n}}\right] .
$$

позначивши

$$
\gamma_{\text {д }}=\sqrt[4]{\frac{C_{n} \cdot b_{p}}{E I}} ; \bar{l}_{\gamma}=l \cdot \gamma_{\text {д }},
$$

отримаємо

$$
\delta_{k k}=\frac{\lambda^{3}}{6 \cdot E I} \cdot\left[\overline{\omega_{k k}}+\frac{6 \cdot 10^{4}}{\overline{l_{\gamma}^{4}}}\right] .
$$




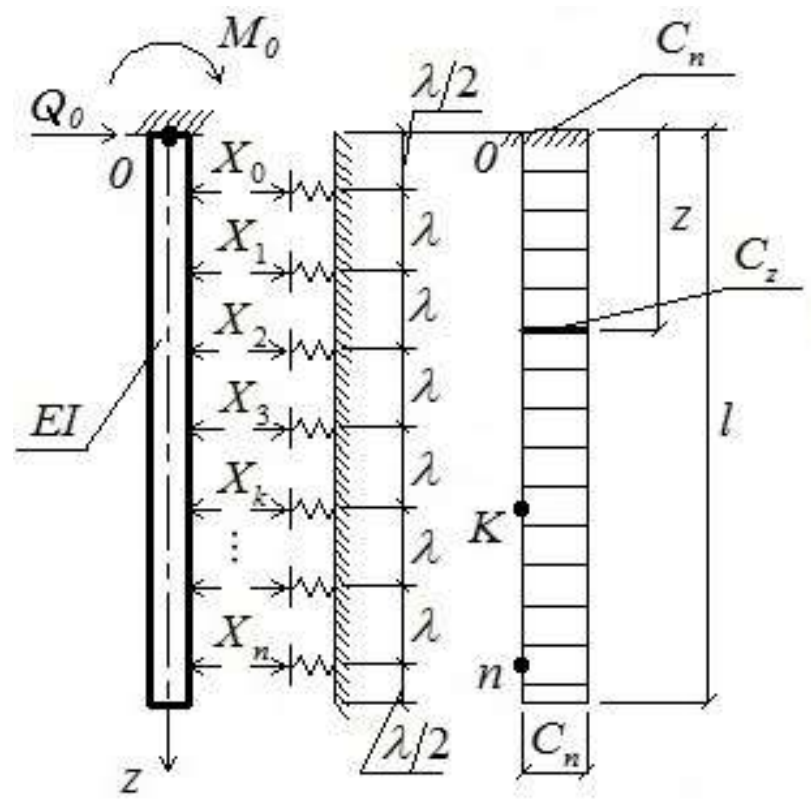

Малюнок 13. Основна система і прямокутна епюра коефіцієнта постелі

\section{Приклад розрахунку 2}

Розглянемо балку на пружній основі $з$ постійним коефіцієнтом жорсткості

В.І. Кузнєцова [43].

Вихідні дані: паля 3 характеристиками $\mathrm{E}=1 \cdot 106$ тс / м2; $I=1.042 \cdot 102 \mathrm{M} 4, \mathrm{~b}=1 \mathrm{~m} ; 1=6 \mathrm{M}$. Грунт характеризується коефіцієнтом жорсткості $C_{n}=5700$ тс / м3. Горизонтальна сила $\mathrm{Q}=10$ тс прикладена на поверхні грунту.

Графіки отриманих значень $y_{z}$ i $M_{z}$ в залежності від z представлені на Мал. 14. Як бачимо, результати розрахунку за нашою методикою і методикою B.I. Кузнєцова [43] можуть бути різними не більше ніж на 3\%.

Аналізуючи отримані результати, можна зробити висновок про те, що запропонований метод дозволяє вірно і досить просто обчислити величини горизонтальних деформацій, згинальних моментів і горизонтальних напружень по боковій поверхні палі.

Даний метод може бути застосований при різній формі розподілу коефіцієнта жорсткості по глибині, що дозволить враховувати роботу горизонтально навантажених паль в різних грунтових умовах. 


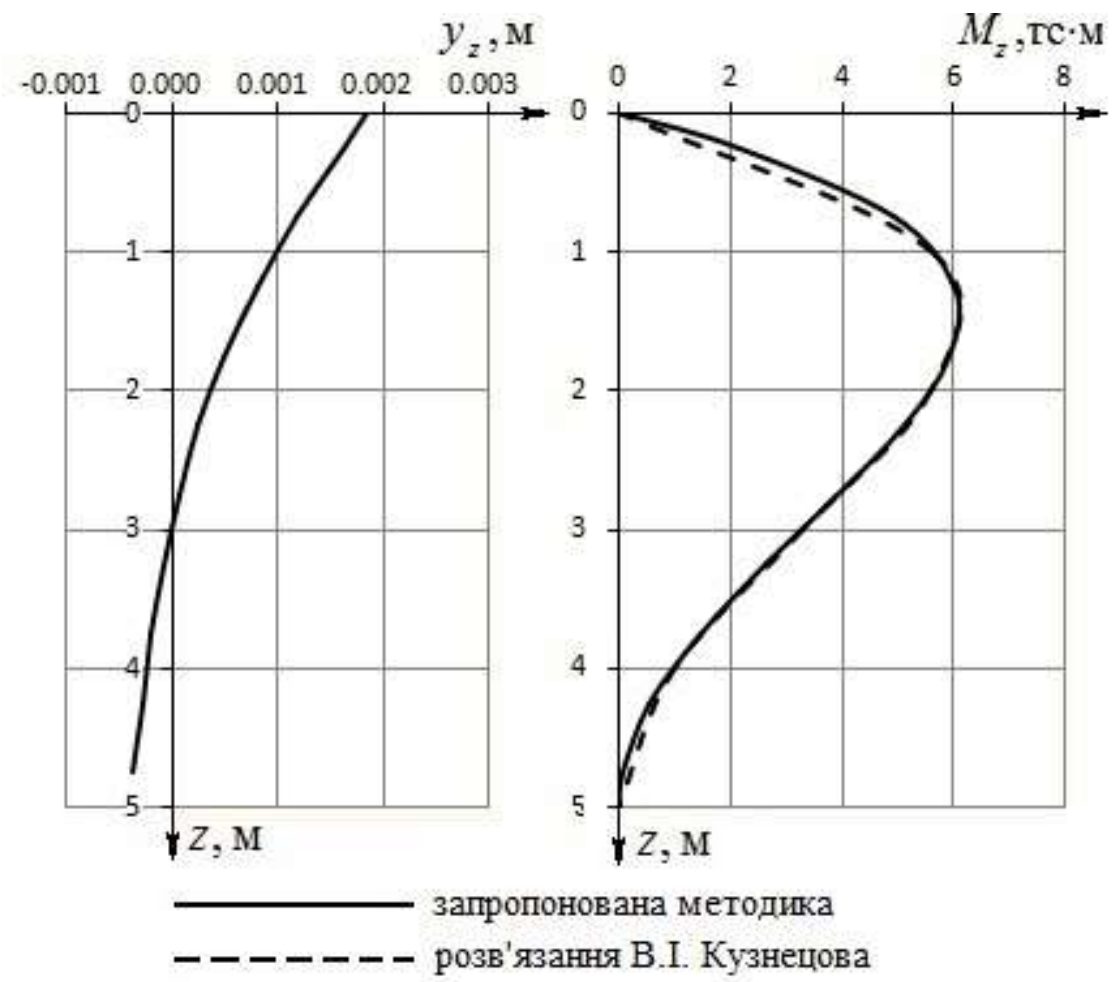

Малюнок 14. Епюри $y_{z}$ i $M_{z}$ на приклад розрахунку 2

За результатами розрахунків для кожної з комплексних моделей, виходячи 3 найбільш використовуваних геометричних і міцності паль, складені таблиці для прямого визначення одиничних сил $X_{k}$, Горизонтальних переміщень $y_{0}$ i згинальних моментів по глибині занурення $M_{z}$. Слід врахувати, що поперечна розподілене навантаження $q$ включається в рівняння рівноваги як сума горизонтальних сил $\sum Q$ і згинальних моментів $\sum M$ щодо точки умовного защемлення «0» у вигляді

$$
\left.\begin{array}{rl}
\sum Q & =q \cdot b \cdot l, \\
\sum M & =\frac{q \cdot b \cdot l^{2}}{2} .
\end{array}\right\} .
$$

Для визначення величин відсічі грунту, згинальних моментів по глибині паль, горизонтальних переміщень і кута повороту в рівні поверхні грунту при розрахунку паль, навантажених горизонтальної силою $Q_{0}$, Необхідно скористатися наступними залежностями 


$$
\left.\begin{array}{c}
y_{0}=\frac{\omega_{0} \cdot Q_{0} \cdot \lambda^{3}}{6 \cdot E I} ; \\
\varphi_{0}=\frac{\varphi_{0}^{\prime} \cdot Q_{0} \cdot \lambda^{2}}{6 \cdot E I} ; \\
\sigma_{z}=\frac{X_{i} \cdot Q_{0}}{b \cdot \lambda} ; \\
M_{z}=M_{i} \cdot Q_{0} \cdot \lambda .
\end{array}\right\} .
$$

Для визначення аналогічних величин при розрахунку паль, навантажених згинаючим моментом $M_{0}$, Необхідно скористатися залежностями

$$
\left.\begin{array}{c}
y_{0}=\frac{\omega_{0} \cdot M_{0} \cdot \lambda^{2}}{6 \cdot E I} ; \\
\varphi_{0}=\frac{\varphi_{0}^{\prime} \cdot M_{0} \cdot \lambda}{6 \cdot E I} ; \\
\sigma_{z}=\frac{X_{i} \cdot M_{0}}{b \cdot \lambda^{2}} ; \\
M_{z}=M_{i} \cdot M_{0} .
\end{array}\right\} .
$$

1.3.1.2. Рішення зворотньої задачі визначення жорсткості основи i напруженого стану горизонтально навантажених паль по заданим деформаціям i зовнішньому навантаженні

Достовірність визначення напружено-деформованого стану палі багато в чому залежать від правильності визначення значень коефіцієнта жорсткості основи і від закону його зміни по глибині.

Далі наведено метод визначення розподілу коефіцієнта жорсткості основи по глибині, виходячи з експериментальних величин горизонтальних переміщень горизонтально завантажених паль.

Порядок розрахунку полягає в наступному. Як і в попередньому пункті 1.1, палю довжиною $l$ розбиваємо на рівні ділянки, в серединах яких ставимо жорсткі стрижні, що забезпечують контакт палі з грунтом. горизонтальні переміщення $u_{k}$ в цих точках отримані з експериментальних досліджень. 
Система канонічних рівнянь являє собою умови рівності нулю суми переміщень у напрямку кожної одиничної сили $X_{k}$ і два рівняння рівноваги. Система вирішується щодо невідомих $C_{k}$.

3 урахуванням

$$
\left.\begin{array}{c}
X_{k}=u_{k} \cdot \lambda \cdot b_{p} \cdot C_{k} ; \\
\delta_{k i}=V_{k k}+w_{k i}=\frac{1}{\lambda \cdot b \cdot C_{k}}+\frac{\lambda^{3}}{6 \cdot E I} \cdot \overline{\omega_{k i}}, \quad(\text { при } k=i) ; \\
\left.\delta_{k i}=w_{k i}=\frac{\lambda^{3}}{6 \cdot E I} \cdot \overline{\omega_{k i}}, \quad \text { (при } k \neq i\right),
\end{array}\right\},
$$

система канонічних рівнянь запишеться в такий спосіб

$$
A \cdot\left|\begin{array}{c}
C_{0} \\
C_{1} \\
\cdots \\
C_{n} \\
\omega_{0} \\
\varphi_{0}^{\prime}
\end{array}\right|=\left|\begin{array}{c}
-\Delta_{0 p} \\
-\Delta_{1 p} \\
\cdots \\
-\Delta_{n p} \\
\sum Q /(\lambda \cdot b) \\
\sum M /\left(\lambda^{2} \cdot b\right)
\end{array}\right|,
$$

де А - квадратна матриця:

$$
A=\left|\begin{array}{cccccc}
u_{0} \cdot\left(\overline{\omega_{00}}+\frac{6 \cdot E I}{\lambda^{4} \cdot b}\right) & u_{1} \cdot \overline{\omega_{01}} & \ldots & u_{n} \cdot \overline{\omega_{0 n}} & 1 & a_{0} \\
u_{0} \cdot \overline{\omega_{10}} & u_{1} \cdot\left(\overline{\omega_{11}}+\frac{6 \cdot E I}{\lambda^{4} \cdot b}\right) & \ldots & u_{n} \cdot \overline{\omega_{1 n}} & 1 & a_{1} \\
\ldots & \ldots & \ldots & \ldots & \ldots & \ldots \\
u_{0} \cdot \overline{\omega_{n 0}} & u_{1} \cdot \overline{\omega_{n 1}} & \ldots & u_{n} \cdot\left(\overline{\omega_{n n}}+\frac{6 \cdot E I}{\lambda^{4} \cdot b}\right) & 1 & a_{n} \\
u_{0} \cdot 1 & u_{1} \cdot 1 & \ldots & u_{n} \cdot 1 & 0 & 0 \\
u_{0} \cdot a_{0} & u_{1} \cdot a_{1} & \ldots & u_{n} \cdot a_{n} & 0 & 0
\end{array}\right| .
$$

Відзначимо, що отримуються з рішення системи (62) значення $\omega_{0}$ i $\varphi_{0}$ збільшені в $\frac{6 \cdot E I}{\lambda^{4} \cdot b}$ раз, де

$C_{k}$ - коефіцієнт жорсткості основи в точці $K$, Тс / м2;

$\omega_{0}$ - горизонтальне переміщення в місці умовної закладення;

$\varphi_{0}$ - кут повороту умовної закладення; 
$\Delta_{n p}$ - вантажні переміщення від зовнішніх сил;

$u_{k}$ - заданий горизонтальне переміщення палі, м;

$a_{k}$ - відстань від точки $K$ до умовної закладення;

$\overline{\omega_{k i}}$ - поодинокі прогини балки в точці $K$ від сили $X_{k}$, Затабульовано в [44].

Після визначення коефіцієнтів жорсткості основи не складає труднощів обчислити розподіл згинальних моментів, горизонтальних сил і відсіч грунту по глибині палі.

\section{Приклад розрахунку 3}

Покажемо, як обчислюються коефіцієнти рівнянь.

Розглянемо експериментальні дослідження паль в слабких грунтах, проведених лабораторією фундаментів i підземних споруд Харківського ПромбудНДІпроекту А.Н. Довгим і Г.С. Лекумовічем під керівництвом Лучковського І.Я. [45], [46].

На експериментальному майданчику м. Первомайська, Харківської області були проведені випробування горизонтально навантажених металевих паль перетином 30х30 см, занурених в грунт на глибину 6 м.

Приступаючи до вирішення завдання, необхідно розбити палю на ділянки. Практично досить від 6 до 10 ділянок. Складаючи рівняння для палі з кількістю ділянок $n=10$ і умовним закріпленням в рівні поверхні грунту, з (62) отримаємо таку систему

$$
A \cdot\left|\begin{array}{c}
C_{0} \\
C_{1} \\
C_{2} \\
C_{3} \\
C_{4} \\
C_{5} \\
C_{6} \\
C_{7} \\
C_{8} \\
C_{9} \\
\omega_{0} \\
\varphi_{0}^{\prime}
\end{array}\right|=\left|\begin{array}{c}
0 \\
0 \\
0 \\
0 \\
0 \\
0 \\
0 \\
0 \\
0 \\
0 /(0.6 \cdot 0.95) \\
\sum M /\left(0.6^{2} \cdot 0.95\right)
\end{array}\right|,
$$


де А - квадратна матриця запишеться з урахуванням одиничних прогинів $\overline{\omega_{k i}}$ від зосереджених сил з таблиці IV [44]:

$$
A=\left|\begin{array}{cccccc}
m_{00} & m_{01} & \ldots & m_{09} & 1 & a_{0} \\
m_{10} & m_{11} & \ldots & m_{19} & 1 & a_{1} \\
\ldots & \ldots & \ldots & \ldots & \ldots & \ldots \\
m_{90} & m_{91} & \ldots & m_{99} & 1 & a_{n} \\
u_{0} & u_{1} & \ldots & u_{n} & 0 & 0 \\
u_{0} \cdot a_{0} & u_{1} \cdot a_{1} & \ldots & u_{n} \cdot a_{n} & 0 & 0
\end{array}\right| .
$$

На основі експериментальних досліджень [47] отримаємо горизонтальні переміщення $u_{k}$ в кожній точці:

$$
\begin{aligned}
& u_{0}=0.01480 ; \\
& u_{1}=0.00866 ; \\
& u_{2}=0.00398 ; \\
& u_{3}=0.00115 ; \\
& u_{4}=-0.0001 ; \\
& u_{5}=-0.00037 ; \\
& u_{6}=-0.00025 ; \\
& u_{7}=-0.00009 ; \\
& u_{8}=-0.00001 ; \\
& u_{9}=0.000018
\end{aligned}
$$

Далі можна отримати числові вирази для елементів матриці $m_{k i}$ i $a_{k} 3$ урахуванням горизонтальних переміщень $u_{k}$ і одиничних прогинів $\overline{\omega_{k i}} 3$ [44]:

$$
\begin{aligned}
& a_{0} \cdot u_{0}=0.5 \cdot 0.01480=0.0074017 ; \\
& a_{1} \cdot u_{1}=1.5 \cdot 0.00866=0.0129867 ; \\
& a_{2} \cdot u_{2}=2.5 \cdot 0.00398=0.0099415 ; \\
& a_{3} \cdot u_{3}=3.5 \cdot 0.00115=0.0040236 ; \\
& a_{4} \cdot u_{4}=4.5 \cdot(-0.0001)=-0.00045 ; \\
& a_{5} \cdot u_{5}=5.5 \cdot(-0.00037)=-0.0020119 ; \\
& a_{6} \cdot u_{6}=6.5 \cdot(-0.00025)=-0.0016185 ; \\
& a_{7} \cdot u_{7}=7.5 \cdot(-0.00009)=-0.000699 ; \\
& a_{8} \cdot u_{8}=8.5 \cdot(-0.00001)=-0.000085 ; \\
& a_{9} \cdot u_{9}=9.5 \cdot 0.000018=0.00017575
\end{aligned}
$$

Вирішуючи отриману систему рівнянь, отримаємо 


$$
\begin{aligned}
& C_{0}=523.69 ; \\
& C_{1}=216.15 ; \\
& C_{2}=1909.29 ; \\
& C_{3}=2482.84 ; \\
& C_{4}=6618.26 ; \\
& C_{5}=6304.97 ; \\
& C_{6}=9321.62 ; \\
& C_{7}=12035.71 ; \\
& C_{8}=17221.5 ; \\
& C_{9}=27338.28 ; \\
& \omega_{0}=-121.06 ; \\
& \varphi_{0}=45.61 .
\end{aligned}
$$

На Мал. 15 дані результати розрахунку палі. Наведено епюри розподілу коефіцієнта жорсткості і згинальних моментів, отриманих з урахуванням значень горизонтальних деформацій по глибині палі.

Як можна помітити, отримана епюра коефіцієнта жорсткості по глибині палі при даних грунтових умовах має увігнутий характер.
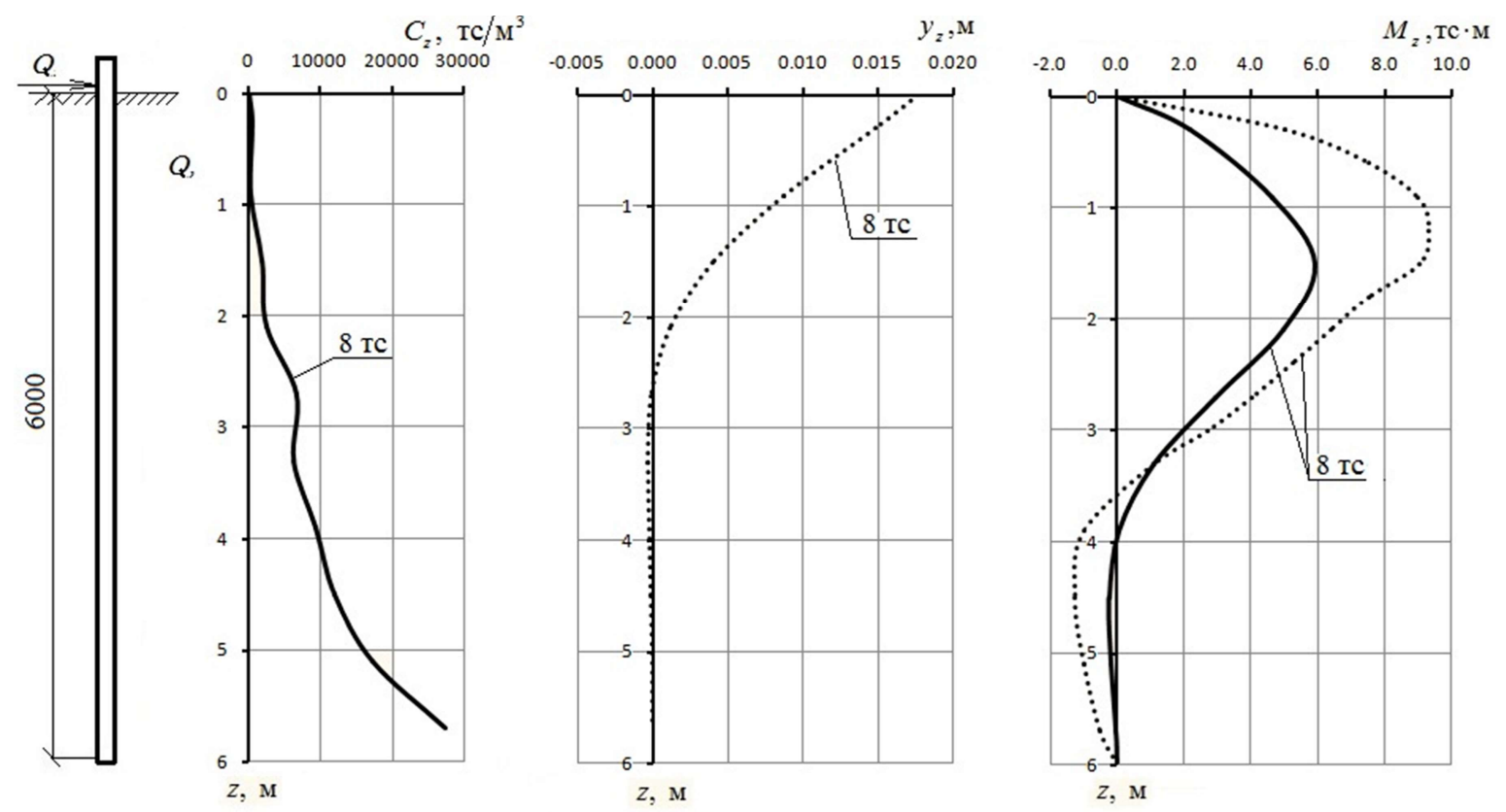

Малюнок 15. Значення коефіцієнта жорсткості грунту $\mathrm{Cz}$, майданчик № 2 (металеві палі) до прикладу розрахунку 3.

Графіки залежності $\mathrm{Cz}=\mathrm{f}(\mathrm{z})$ при $\mathrm{Q}=8 \mathrm{Tc}, \mathrm{yz}=\mathrm{f}(\mathrm{Q})$, епюри згинальних моментів у функції від зовнішнього навантаження $(\mathrm{Mz}=\mathrm{f}(\mathrm{Q}))$ (Суцільна лінія запропонована методика; пунктирна лінія - експериментальні дані) 
1.3.1.3. Урахування неоднорідної (багатошарової) грунтової основи при розрахунку горизонтально навантажених паль

Нормативної методикою [48] передбачено приведення неоднорідної основи до умовно однорідної в зв'язку зі складнощами розрахунку. Далі наведено метод розрахунку палі, зануреної в багатошарову основа Вінклера, заснований на методі Б.Н. Жемочкіна [40].

Порядок розрахунку такий же, як і в п. 1.1.

При змінному законі $C(z)$ (Мал. 16) по довжині балки обчислюємо осадку основи $\overline{V_{k k}}$ в точці $K$ за формулою (14) виходячи з відповідного їй коефіцієнта жорсткості основи.

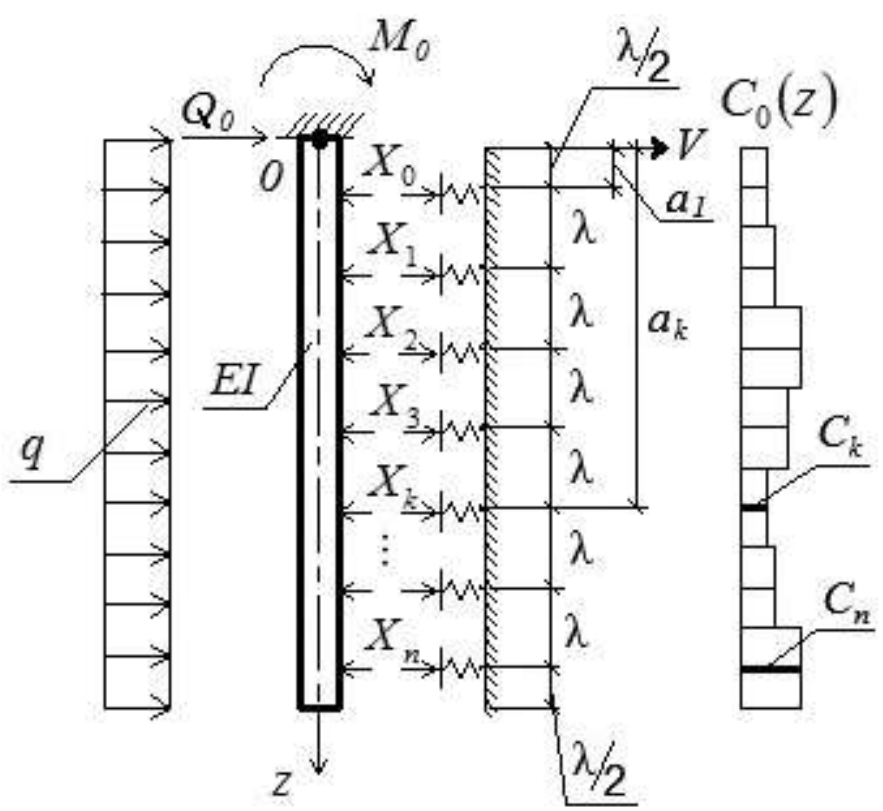

Малюнок 16. Розрахункова схема палі, зануреної в багатошарову основу

\section{Приклад розрахунку 4}

Розглянемо горизонтально завантажену палю діаметром $\mathrm{D}=1$ м, при наступних вихідних даних: $1=12$ м. Жорсткість палі: $E I=133.2 \cdot 103 \mathrm{тc} \cdot$ м Горизонтальна сила, прикладена до палі в рівні поверхні грунту, Q $=10$ тс.

a) Розрахуємо перший випадок, при якому двошарове підставу характеризується коефіцієнтами пропорційності: К1 $=500 \mathrm{Tc} / \mathrm{M} 4$, $K 2=1000 \mathrm{тc} / \mathrm{M} 4,11=1.2 \mathrm{м}($ Мал. 17). 
Розбиваємо палю на 10 рівних ділянок довжиною $\lambda=1.2$ м і обчислюємо за формулою (65) і (64) в кожній точці $K$ значення $\delta_{k k}$. Складемо систему канонічних рівнянь за формулами (67) і (68). Вирішивши iї, отримаємо значення невідомих $X_{n}, \omega_{0}, \varphi_{0}$.

За цим значенням неважко обчислити відсіч і прогин палі. Отримані значення наведені на Мал. 17.

б) Викликає також інтерес другий випадок, при якому грунт характеризується коефіцієнтом пропорційності: К1 = 1000 тс / M4, К2 = 500 тс / M4, $11=1.2$ м (Мал. 18).

Обчислені контактний тиск і прогини палі, наведені на Мал. 18.


Малюнок 17. Розрахункова схема і епюри $y_{z}, M_{z}$ i $\sigma_{z}$ наприклад розрахунку 4 а) (Суцільна лінія - запропонована методика; пунктирна лінія розрахунок за «SCAD»; штрихпунктирна лінія - методика «Керівництва») 

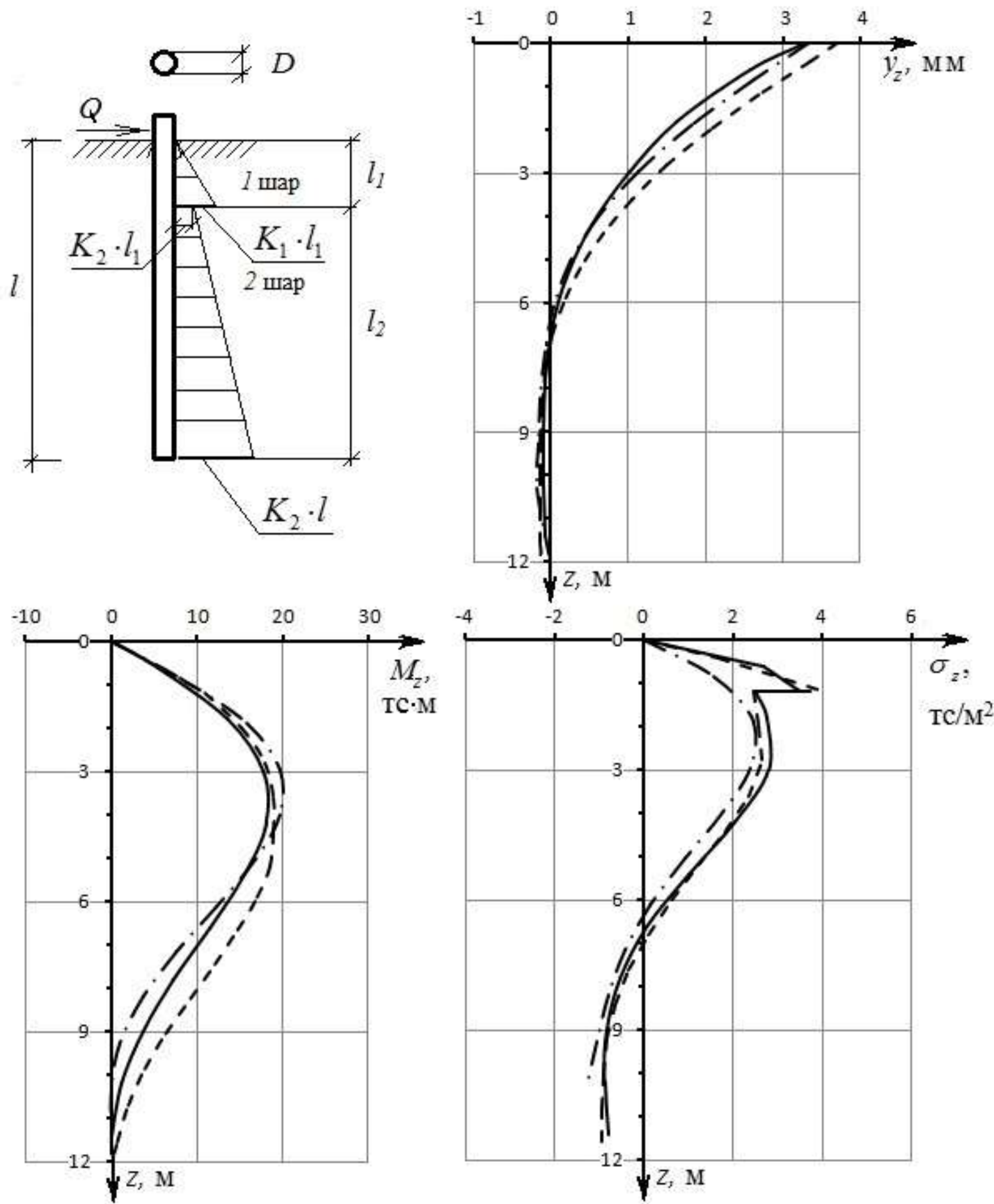

Малюнок 18. Розрахункова схема і епюри $y_{z}, M_{z}$ i $\sigma_{z}$ наприклад розрахунку 4 б) ) (Суцільна лінія - запропонована методика; пунктирна лінія розрахунок за «SCAD»; штрихпунктирна лінія - методика «Керівництва») 
На основі порівняння результатів, отриманих за пропонованою методикою, з результатами розрахунку по «Керівництву» [48] (за величинами горизонтальних деформацій, згинальних моментів і контактних тисків) для обох випадків розподілу коефіцієнта жорсткості основи можна зробити висновок, що запропонована методика, на відміну від методики «Керівництва», дозволяє врахувати неоднорідність основи і вірно оцінити напружено-деформований стан горизонтально навантажених паль, що підтверджується розрахунком, виконаним за допомогою розрахункового комплексу «SCAD».

Запропонована методика відрізняється на 15\% за деформаціями і до $10 \%$ за величиною максимального моменту від методики, наведеної в «Керівництві», і практично збігається з розрахунком в ПК «SCAD».

1.3.2 Облік поперечного навантаження, розподіленого по довжині палі

Слід зазначити, що за методикою «Довідника проектувальника» [49] горизонтальний тиск g, що виникає в заанкерених частини гнучких підпірних пальових та інших стін з боку засипки (Мал. 19), не враховується, а розрахунок напружено-деформованого стану підземної частини палі (шпунта) проводиться на дію равнодействующих $Q_{0}$ і $M_{0}$ на рівні закладення палі. Крім того, розрахунок необхідної кількості робочої (поздовжньої) арматури паль, або несучої здатності стін, виробляється на дію внутрішніх зусиль, яких визначали за пружною стадії роботи стіни, що спирається на Вінклерово підставу 3 використанням моделі основи 3 лінійно зростаючим по глибині коефіцієнтом постелі [50], [42], [48].

Така практика розрахунку гнучких стін пов'язана 3 недооцінкою додаткового навантаження g і ігноруванням запасу міцності стін у граничному стані в системі «паля-грунт».

На Мал. 19 представлена розрахункова схема гнучкої підпірної стінки в пружній стадії і в граничному стані при розподілі епюри коефіцієнта постелі у вигляді трапеції

$$
C_{z}=C_{0}+K \cdot z
$$


де $C_{0}$ - коефіцієнт постелі в рівні закладення палі в грунт, тс $/ \mathrm{m}^{3}$;

$K$ - коефіцієнт пропорційності, тс/м².

Епюра відсічі грунту в зоні граничної рівноваги представлена у вигляді

$$
a_{z}=a_{0}+a_{1} \cdot z,
$$

де $a_{0}, a_{1}$ - показники міцності, тс/ $\mathrm{M}^{3}$.

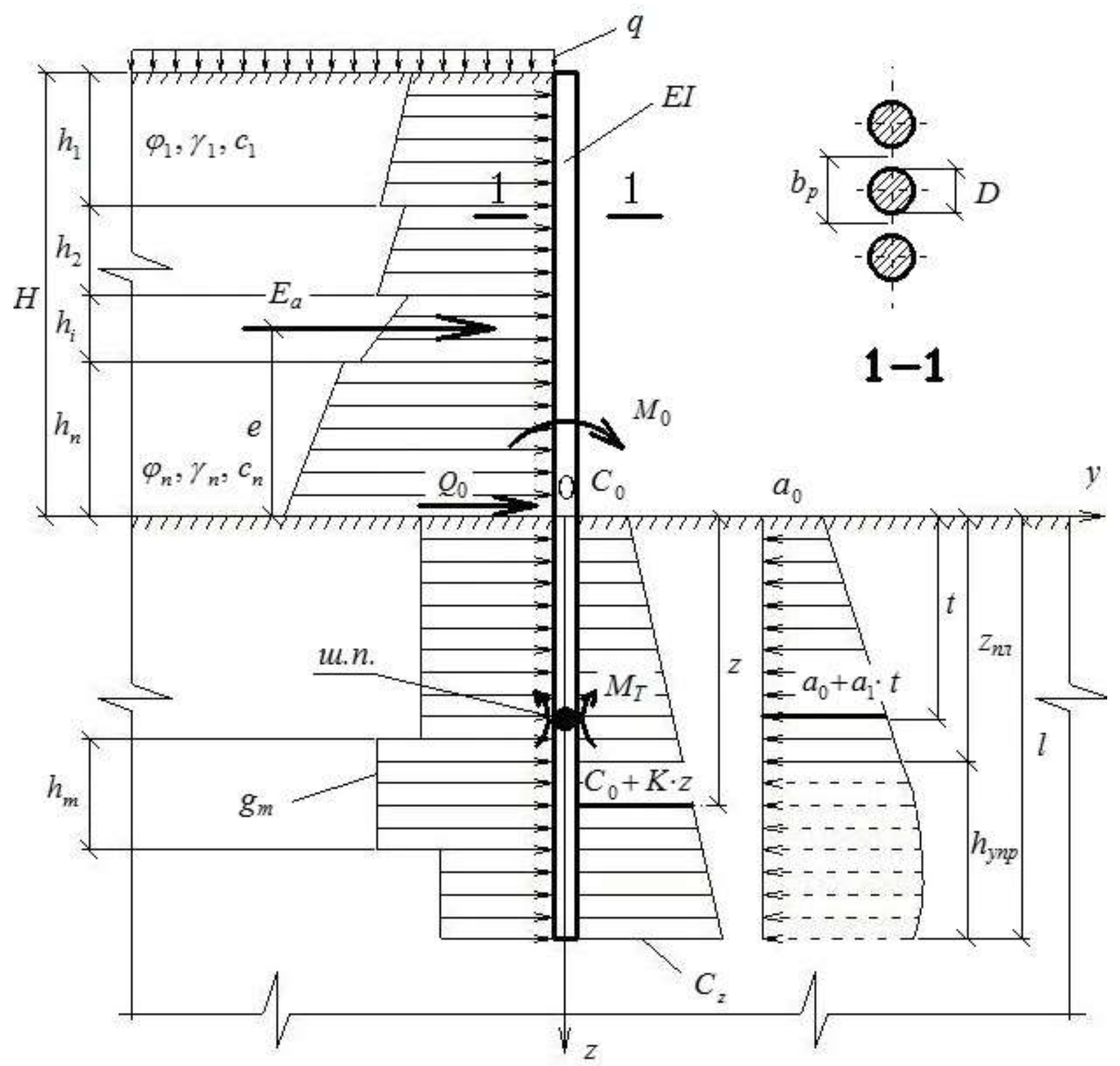

Малюнок 19. Розрахункові схеми взаємодії підпірної стіни з грунтом в пружній стадії і в граничному стані

При цьому прийняті наступні позначення:

$q$ - рівномірно розподілене навантаження на поверхні засипки, тс / м2; 
$E a$ - сумарний активний тиск на 1 п.м. стінки в межах засипання висотою $\mathrm{H}$;

$e$ - відстань від рівнодіючої активного тиску Еа до рівня закладення палі в грунт, м;

$Q_{0}=E_{a}$ - горизонтальне зусилля, що діє на палю в рівні іï закладення в грунт, тс;

$M_{0}=E_{a} \cdot e-$ згинальний момент в рівні закладення палі в грунт, тс·м;

$D$ - діаметр (сторона) поперечного перерізу палі, м;

$b_{p}$ - розрахункова ширина поперечного перерізу палі, м;

$t$ - глибина освіти шарніра пластичності (ш.п.) в палі від рівня закладення палі в грунт, м;

$l$ - довжина заглибленої частини палі, м;

$z_{n л}$ - зона пластичної роботи грунту, м;

$h_{y n p}$ - зона пружною роботи грунту і палі, м;

u.n. - шарнір пластичності, що утворюється в стовбурі палі при досягненні граничного стану системою «паля-грунт»;

$g_{m}$ - додаткове навантаження на заглиблені частина палі на 1 п.м. довжини стіни в шарі т, викликана засипанням і навантаженням q, тс / м2,

$$
g_{m}=\left(q+\sum_{1}^{n} \gamma_{i} \cdot h_{i}\right) \cdot \lambda_{a m}
$$

$\lambda_{a m}$ - коефіцієнт бокового тиску грунту m-го шару заглибленої частини палі;

$M_{T}$ - граничний згинальний момент, що сприймається розрахунковим перерізом палі, тс·м .

1.3.2.1. Пружна стадія роботи палі і однорідного грунтового масиву

Величини зусиль і деформацій в палях стіни в пружній стадії при трикутній епюрі коефіцієнта постелі визначаються відповідно до «Керівництва» [48], а у випадку з трапецеидальною епюрою коефіцієнта постелі застосовується метод «фіктивних початкових параметрів» І.Я. Лучковського [45] або рішення А.С. Маліева [42]. 
1.3.2.2. Визначення несучої здатності палі в граничному стані

У граничному стані, що виникає при утворенні пластичного шарніра в зоні граничної рівноваги грунту на глибині t (Мал. 20), повинні виконуватися дві умови

$$
\begin{gathered}
Q_{t}=0 ; \\
M_{t}=M_{T} .
\end{gathered}
$$

3 умови (67) отримаємо

$$
\frac{a_{1} \cdot t^{2}}{2}-\left(a_{0}-g\right) \cdot t-Q_{0}=0 .
$$

Потім, після деяких перетворень, знайдемо глибину t:

$$
t=\frac{1}{a_{1}}\left[\left(g-a_{0}\right)+\sqrt{\left(g-a_{o}\right)^{2}+2 a_{1} \cdot Q_{0}}\right] .
$$

3 умови (68) знайдемо необхідне значення граничного згинального моменту МТ

$$
M_{T}=b_{p}\left[M_{0}+\mathrm{Q}_{0} \cdot t+\left(g-a_{o}\right) \frac{t^{2}}{2}-\frac{a_{1} t^{3}}{6}\right] .
$$

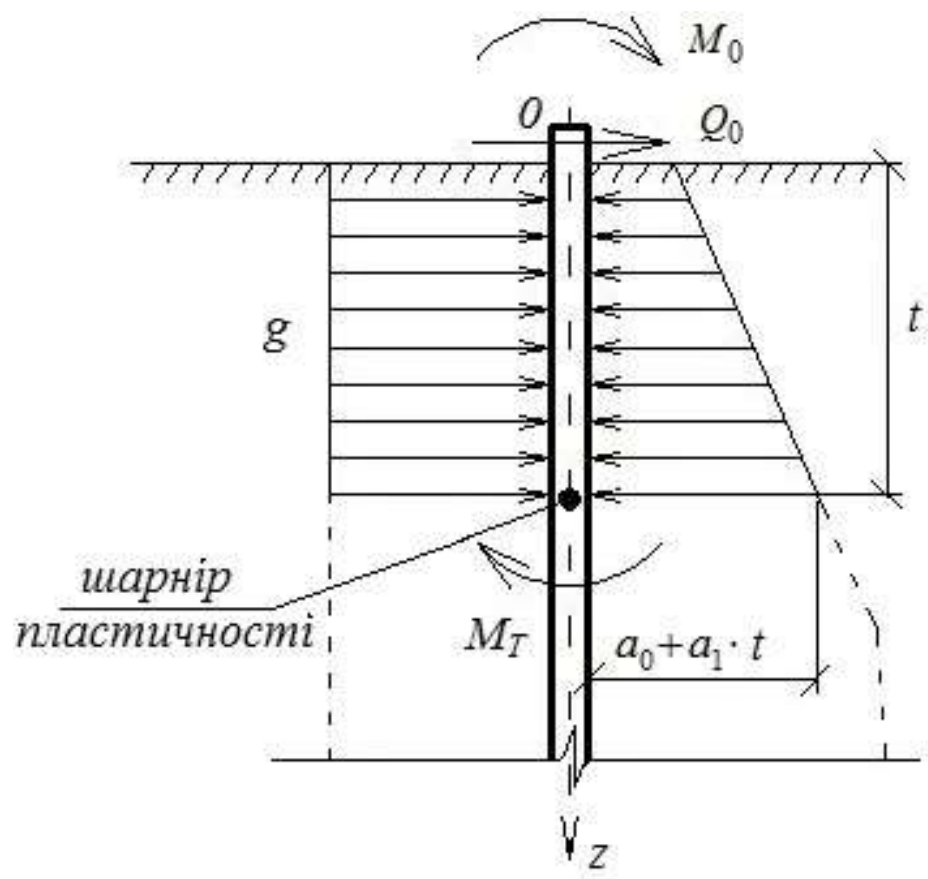

Малюнок 20. Схема граничного стану заглибленої частини палі 


\section{Приклад розрахунку 5}

Як приклад розглянемо пальових стінку 3 паль діаметром $D=1$ м (Мал. 21), при наступних вихідних даних: $\mathrm{H}=6 \mathrm{~m} ; 1=12 \mathrm{~m} ; \mathrm{q}=0$. Жорсткість однієї палі: $E I=1.37445 \cdot 10^{5} \mathrm{Tc} \cdot \mathrm{M}^{2}$

Грунт по всій глибині палі має наступні характеристики: $\varphi=30^{\circ}$ (пісок); $K$ $=600 \mathrm{Tc} / \mathrm{M}^{4} ; \quad a_{1}=6.0 \mathrm{Tc} / \mathrm{m}^{3} ; \quad a_{0}=0$. Коефіцієнт деформації $\alpha_{\text {д }}=0.337 \mathrm{M}^{-1}$. Наведена довжина заглибленої частини палі $\bar{l}=l \cdot \alpha_{\text {д }} \approx 4$..

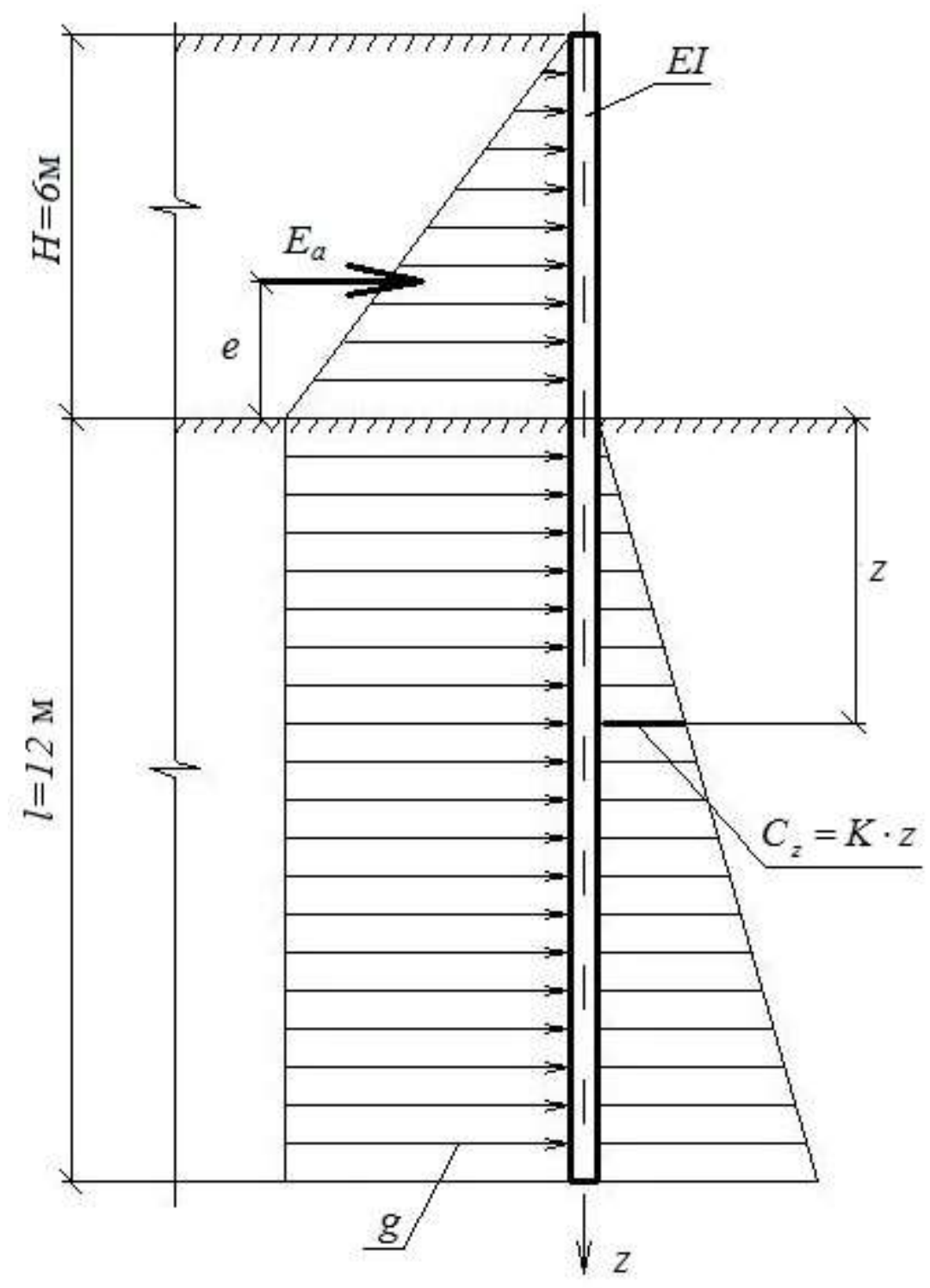

Малюнок 21 Розрахункова схема до прикладу розрахунку 5

Розглянемо чотири варіанти розрахунку свайної стінки. 
1) Розрахунок в пружній стадії за методикою, викладеною в «Довіднику проектувальника» [49], без урахування додаткового навантаження g.

Відповідно до «Керівництва» [48], побудуємо епюру моментів від зовнішніх навантажень $Q_{0}=12 \mathrm{Tc}, M_{0}=24 \mathrm{Tc} \cdot$ м, по глибині занурення палі (Мал. 22 а). У цьому випадку максимальний момент дорівнює:

$$
\operatorname{Mmax}=46.15 \mathrm{Tc} \cdot \mathrm{M} .
$$

Що відповідає глибині $z=\frac{1.12}{\alpha_{g}}=3.32$ м.

2) Розрахунок в пружній стадії з урахуванням додаткового навантаження g.

Використовуючи рішення А.С. Маліева [42], знайдемо моменти від додаткового навантаження $g=4$ тc/м² (Мал. 22 б) по висоті палі. Підсумовуючи величини отриманих моментів зі знайденими розрахунком по «Керівництву» [48]. Визначимо максимальний момент по результуючій епюрі (Мал. 22 в).

$$
z=3.32 \mathrm{M} ; \operatorname{Mmax}=54.76 \mathrm{Tc} \cdot \mathrm{M} .
$$

3) Розрахунок за граничним станом системи «паля-грунт» без урахування додаткового навантаження g.

За формулами $(74,75,76)$ знайдемо:

$$
t=2 \mathrm{M} ; \mathrm{MT}=40 \mathrm{Tc} \cdot \mathrm{M}<\mathrm{Mmax}=46.15 \mathrm{Tc} \cdot \mathrm{M} .
$$

4) Розрахунок за граничним станом 3 урахуванням додаткового навантаження $\mathrm{g}$.

За формулою (75) знайдемо

$$
t=\frac{1}{6}(4+\sqrt{16+2 \cdot 12 \cdot 6})=2.775 \mathrm{M},
$$

потім за формулою (76) при $b_{p}=D=1$ м и $g=4 \mathrm{Tc} / \mathrm{M}^{2}$ отримаємо

$$
M_{T}=24+12 \cdot 2.775+4 \cdot \frac{2.775^{2}}{2}-\frac{6 \cdot 2.775^{3}}{6}=51.33 \mathrm{Tc} \cdot \mathrm{M} .
$$



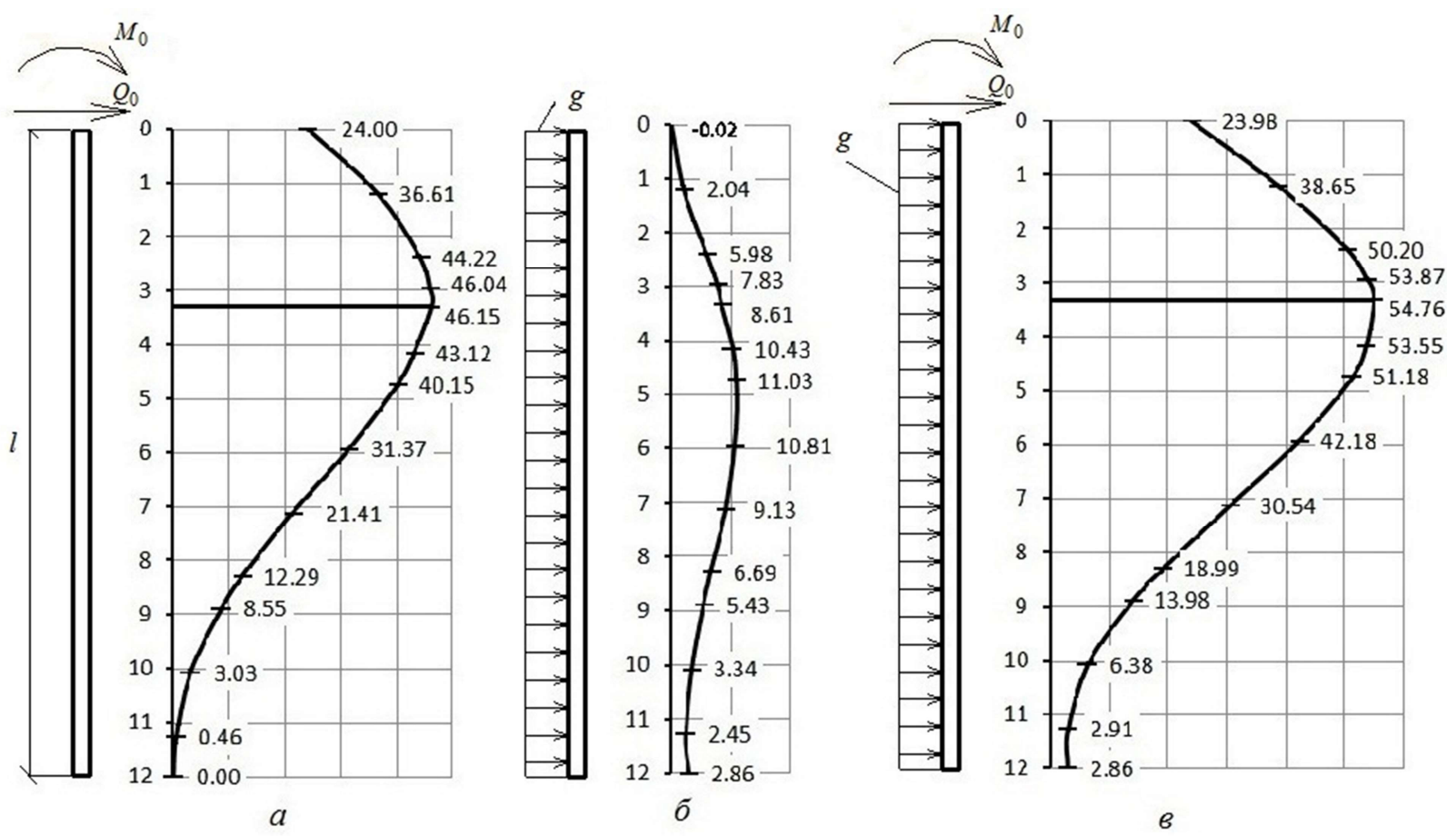

Малюнок 22. Епюри згинальних моментів в підпірної стінки

а) по «Керівництву» [48]; б) з рішення А.С. Маліева [42] від навантаження g; в) сумарна

Виконаний аналіз роботи свайної підпірної стінки показав, що рекомендована в «Довіднику проектувальника» [49] методика розрахунку, не враховує наявність поперечної навантаження по довжині палі, переоцінює реальну несучу здатність палі, що може призводити до аварійних ситуацій. В даному прикладі це становить $18 \%$.

\subsection{3. Вигин палі в грунті, що має повзучість}

Повзучість Вінклерової основи призводить до нерівномірної зміни контактних напружень фундаментів і горизонтально навантажених паль, а також до нерівномірного зростанню деформацій конструкцій в часі.

У початковий момент навантаження конструкції зв'язок між контактним тиском і осадкою деякої точки підошви фундаменту $V_{0}$ описується елементарної лінійної залежністю типу закону Гука

$$
V_{0}=\frac{\sigma_{0}}{C_{0}},
$$

де $\sigma_{0}$ - контактне напруження, тс/м²; 
$C_{0}$ - коефіцієнт постелі, тс/м².

При тривалому навантаженні фундаментів (паль) на основі, що володіє реологическими властивостями, зв'язок величин $V_{t}, \sigma_{t}$ i $C_{t}$ істотно ускладнюється і описується інтегральними рівняннями ряду теорій пружноповзучого тіла (старіння, спадковості і ін.), які враховують закони зміни контактних напружень і властивостей матеріалів в часі.

При розробці практичних методів розрахунку значні спрощення досягаються за рахунок подання інтегральних реологічних рівнянь в алгебраїчній формі.

Одним із прийомів, що спрощують рішення контактних задач, може бути запропонований I.Я. Лучковським метод «тимчасового коефіцієнта постелі» [45], [51], який видається для будь-якого моменту часу t у вигляді

$$
C_{t}^{i}=\frac{\sigma_{t}^{i}}{V_{t}^{i}}
$$

де $C_{t}^{i}$ - тимчасовий коефіцієнт постелі в довільній точці і контакту в момент часу $t, \mathrm{Tc} / \mathrm{M}^{3}$

$\sigma_{t}^{i}$ - контактне напруження в точці і в момент часу $t, \mathrm{Tc} / \mathrm{M}^{2}$;

$V_{t}^{i}$ - деформація (осаду) і-тої точки в момент часу $t$, м.

Приймаючи різні законами зміни контактних напружень в часі, в роботі [45] було отримано кілька видів алгебраїчних реологічних рівнянь лінійної і нелінійної повзучості.

Наприклад, для нелінійної повзучості з використанням теорії старіння при функції нелінійності виду

$$
f(\sigma)=a \cdot \sigma+\beta \cdot \sigma^{2}
$$

і прийнятті постійного пружно-миттєвого коефіцієнта постелі $C_{\tau}=C_{0}$ отримані реологічні рівняння

при $a=1$ : 


$$
2 \cdot C_{0} \cdot V_{t}=\varphi_{t} \cdot\left[\sigma_{0}+\sigma_{t} \cdot\left(1+\frac{2}{\varphi_{t}}+2 \cdot \beta \cdot \sigma_{0}\right)\right]
$$

при $a=0$ :

$$
C_{0} \cdot V_{t}=\sigma_{t} \cdot\left(1+\beta \cdot \varphi_{t} \cdot \sigma_{0}\right),
$$

де $\varphi_{t}$ - характеристика повзучості.

При $a=1$ і $\beta=0$ з (75) приходимо до реологічних рівняннь лінійної повзучості, отриманих раніше Чжан Чжун-яо с використанням теореми про повну загальну середню

$$
2 \cdot C_{0} \cdot V_{t}=\varphi_{t} \cdot\left[\sigma_{0}+\sigma_{t} \cdot\left(1+\frac{2}{\varphi_{t}}\right)\right] .
$$

Диференціальне рівняння вигину балки на пружно-повзучій Вінклеровій основі в загальному випадку змінної жорсткості основи має вигляд

$$
E I \cdot V_{t}^{I V}+C_{t}^{z} \cdot V_{t}^{z}=q(z) .
$$

Використовуючи залежність (73) для тимчасового коефіцієнта постелі $C_{t}$ i алгебраїчні реологічні рівняння лінійної і нелінійної повзучості (75), (76), (77), замінивши в (78) $C_{t} \cdot V_{t}$ на $\sigma_{t}$, Отримаємо різні диференціальні рівняння, що враховують повзучість Вінклерової основи.

1. При лінійній повзучості з виразу (77) знайдемо $\sigma_{t}$

$$
\sigma_{t}=C_{t} \cdot V_{t}=\frac{2 \cdot C_{0} \cdot V_{t}-\varphi_{t} \cdot \sigma_{0}}{2+\varphi_{t}}
$$

а потім диференціальне рівняння

$$
E I \cdot V_{t}^{I V}(z)+\frac{C_{0}{ }^{z}}{\left(1+0.5 \cdot \varphi_{t}\right)} \cdot V_{t}^{z}=q(z)+\frac{\varphi_{t} \cdot \sigma_{0}{ }^{z}}{\left(2+\varphi_{t}\right)},
$$

де $q(z)$ - інтенсивність зовнішнього навантаження, тс / м

При нелінійної повзучості і $a=1$ (80) знайдемо спочатку $\sigma_{t}$

$$
\sigma_{t}=\frac{2 \cdot C_{0} \cdot V_{t}-\sigma_{0} \cdot \varphi_{t}}{\left(\varphi_{t}+2+2 \cdot \beta \cdot \sigma_{0} \cdot \varphi_{t}\right)}
$$

а потім саме рівняння 


$$
E I \cdot V_{t}^{I V}(z)+\frac{C_{0}{ }^{z}}{1+0.5 \cdot \varphi_{t}+\beta \cdot \sigma_{0}{ }^{2} \cdot \varphi_{t}} \cdot V_{t}^{z}=q(z)+\frac{\sigma_{0}{ }^{z}}{1+\frac{2}{\varphi_{t}}+2 \cdot \beta \cdot \sigma_{0}{ }^{z}} .
$$

3. При нелінійній повзучості і $a=0$ з (76) знайдемо

$$
\sigma_{t}=\frac{C_{0} \cdot V_{t}}{\left(1+\beta \cdot \sigma_{0} \cdot \varphi_{t}\right)}
$$

а потім отримаємо рівняння вигину балки (палі)

$$
E I \cdot V_{t}^{I V}(z)+\frac{C_{0}{ }^{z}}{1+\beta \cdot \sigma_{0}{ }^{z} \cdot \varphi_{t}} \cdot V_{t}^{z}=q(z)
$$

Розглядаючи структуру отриманих диференціальних рівнянь (79), (80) i (81), відзначимо, що враування повзучості основи може бути здійснено після отримання пружно-миттєвого рішення при $t=0$.

Потім використовується в лівій частині рівняння нове значення коефіцієнта пропорційності, що враховує $\varphi_{t}$, початкові значення коефіцієнта постелі $C_{0}(z)$ i змінні по довжині z початкові напруги відпору грунту $\sigma_{0}(z)$. Крім того, в праву частину рівнянь можуть включатися члени, що враховують додаткове навантаження, нерівномірно розподілене вздовж стрижня, що залежить від тривалості навантаження і пружно-миттєвого розподілу контактного тиску.

Відзначимо, що, на відміну від рівнянь, отриманих в роботі [45], представлені вище рівняння (79), (80), (81) враховують довільний закон розподілу коефіцієнта постелі $C_{0}(z)$ по довжині конструкції і змінні вздовж осі $z$ додаткові вантажні члени.

1.3.3.1. Розрахунок паль за допомогою канонічних рівнянь звичайного вигляду

Найбільш зручний в рішенні отриманих рівнянь виявляється метод Б.М. Жемочкіна [40], який вже раніше був застосований декількома авторами [52], [53] до розрахунку конструкцій на пружній Вінклеровій основі. 


\subsubsection{1. Пружно-миттєва стадія}

При змінному законі $C_{0}(z)$ по довжині балки в пружні стадії використовується змішаний метод (Мал. 23), описаний в п. 1.1.

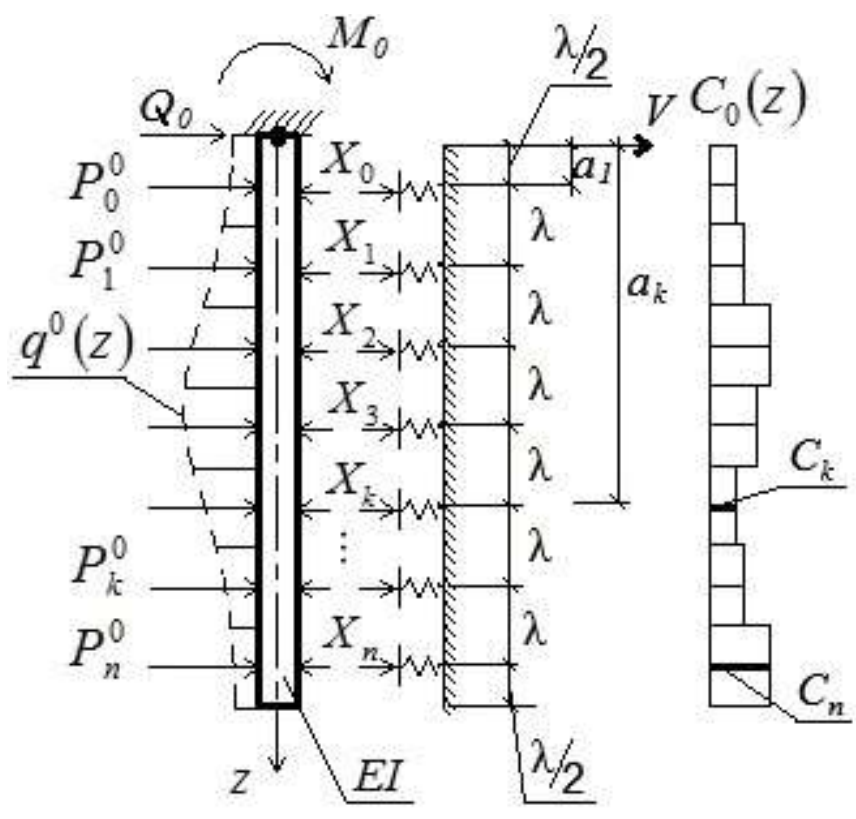

Малюнок 23. Розрахункова схема палі в пружній стадії роботи при поперечному навантаженні розподіленим навантаженням

Необхідно врахувати, що зовнішнє розподілене навантаження $q(z)$ замінюється зосередженими силами $P_{i}^{0}$, А це дозволяє вантажні переміщення від цих сил виразити у вигляді

$$
\Delta_{k p}^{0}=\frac{\lambda^{3}}{6 \cdot E I} \cdot \sum_{1}^{n} P_{i}^{0} \cdot \overline{w_{k i}} .
$$

\subsubsection{3. Стадія тривалого навантаження}

Приймається умова сталості розподіленого навантаження $q(z)$ i зосереджених спочатку координат навантажень $Q_{0} \mathrm{i} M_{0}$. При тривалому навантаженні змінюється (зростає) характеристика повзучості основи $\varphi_{t}$, що призводить до зміни жорсткості основи і появі уздовж балки додаткового розподіленого навантаження $g_{t}(z)$. 
Розглянемо запропоновані варіанти врахування лінійної і нелінійної повзучості грунту (або іншого матеріалу) основи.

а) Лінійна повзучість основи

Розглядаючи отримане вище диференціальне рівняння (79), відзначимо, що при лінійної повзучості Вінклерової основи жорсткість його елементів в будь-який час навантаження $t$, по всій опорній поверхні знижується в одну і ту ж кількість разів і залежить тільки від тривалості дії постійного навантаження

$$
C_{t}(z)=\frac{C_{0}(z)}{1+0.5 \cdot \varphi_{t}} .
$$

Крім того, як видно з рівняння (79), врахування повзучості основи призводить до появи додаткового навантаження $g_{t}(z)$, Що залежить від пружно-миттєвого розподілу відсічі $\sigma_{0}(z)$ і тривалості навантаження

$$
g_{t}(z)=\sigma_{0}(z) \cdot \frac{\varphi_{t}}{\left(2+\varphi_{t}\right)}
$$

Це навантаження замінюється системою зосереджених сил $P_{i}^{t}$.

На основи вищесказаного розрахункова схема палі в стадії лінійної повзучості має вигляд (Мал. 24).

Вантажні переміщення від додаткового навантаження $g_{t}(x)$ визначаються за формулою (85), аналогічно (82)

$$
\Delta_{k p}^{t}=\frac{\lambda^{3}}{6 \cdot E I} \cdot \sum_{1}^{n} P_{i}^{t} \cdot \overline{w_{k i}}
$$

Сумарні вантажні переміщення від сил $P_{i}^{0}$ i $P_{i}^{t}$ визначаються за формулою

$$
\Delta_{k p}=\frac{\lambda^{3}}{6 \cdot E I} \cdot \sum_{1}^{n}\left(P_{i}^{0}+P_{i}^{t}\right) \cdot \overline{w_{k i}} .
$$




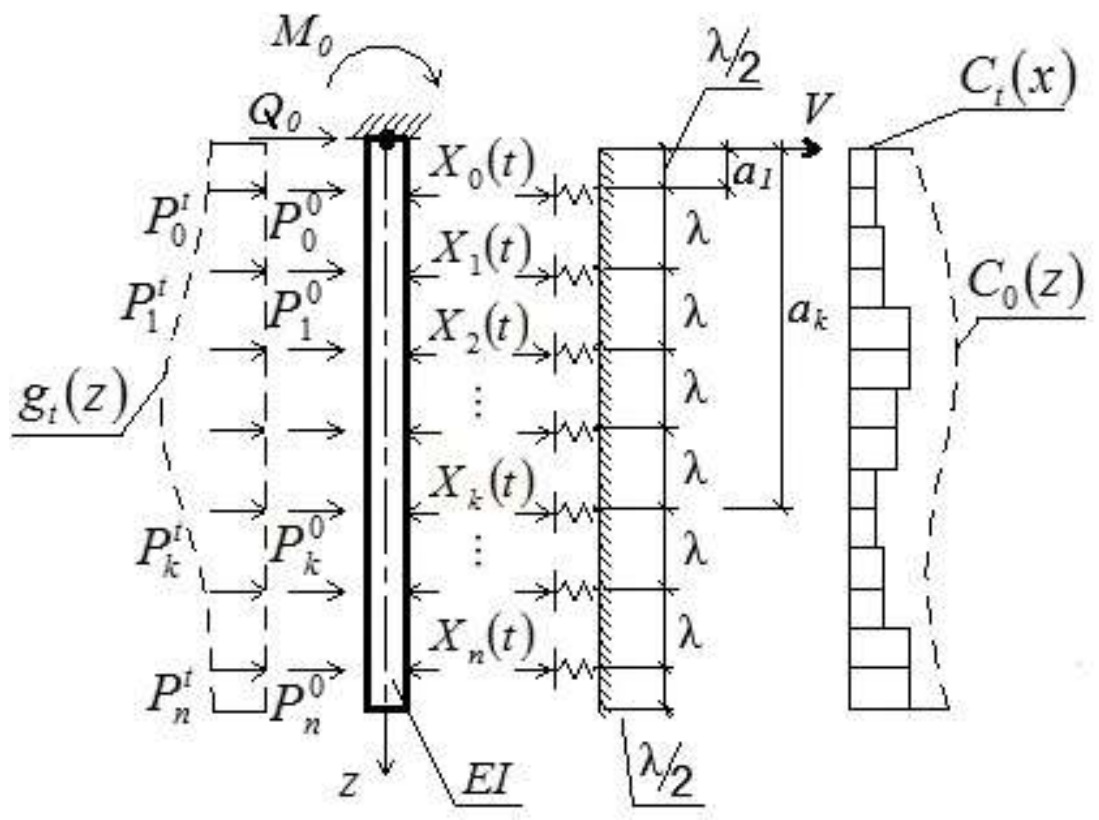

Малюнок 24. Розрахункова схема палі при урахуванні лінійної повзучості основи

б) Нелінійна повзучість основи $X_{k}(t)$

- Спочатку розглянемо основи при функції нелінійності що описується закономірністю (74) при $a=0$, тобто при

$$
f(\sigma)=\beta \cdot \sigma^{2},
$$

яка веде до диференціальних рівнянь вигину палі (81).

Зручність використання цього рівняння очевидна, тому що в правій частині вантажна функція $q(z)$ не змінюється в часі. Тому вантажні члени не змінюються

$$
\Delta_{k p}^{0}=\Delta_{k p}^{t} .
$$

Що ж стосується коефіцієнта постелі $C_{t}(z)$, рівного

$$
C_{t}(z)=\frac{C_{0}(z)}{1+\beta \cdot \varphi_{t} \cdot \sigma_{0}(z)},
$$

то він нелінійно змінюється по довжині конструкції, так як залежить від змінного розподілу відпору грунту уздовж палі при пружно-миттєвому навантаженні. Тому (14), (15) і (16) в даному випадку слід записати у вигляді 


$$
\left.\begin{array}{rl}
V_{k k}^{t} & =\frac{1}{\lambda \cdot b \cdot C_{k}^{t}} ; \\
\delta_{k k}^{t} & =\frac{\lambda^{3}}{6 \cdot E I} \cdot\left(\gamma_{k}^{t}+\overline{\omega_{k k}}\right) ; \\
\gamma_{k}^{t} & =\frac{6 \cdot E I}{b \cdot \lambda^{4} \cdot C_{k}^{t}} .
\end{array}\right\} .
$$

Розрахункова схема палі в цьому випадку залишається аналогічною розрахунковій схемі в пружно-миттєвої стадії (Мал. 23), де коефіцієнти постелі замінені на $C_{i}^{t}$.

Далі розглянемо основу при $a=1$ i $f(\sigma)$ рівну

$$
f(\sigma)=\sigma \cdot(1+\beta \cdot \sigma),
$$

на основі якої отримано диференціальне рівняння (80).

Розрахункова схема палі в даному випадку збігається зі схемою, представленою на Мал. 24.

При цьому вираз для тимчасового коефіцієнта постелі $C_{t}(z)$ і для додаткового навантаження $g_{t}(z)$ змінюються:

$$
\begin{aligned}
& C_{t}(z)=\frac{C_{0}(z)}{1+0.5 \cdot \varphi_{t}+\varphi_{t} \cdot \beta \cdot \sigma_{0}(z)}, \\
& g_{t}(z)=\frac{\sigma_{0}(z)}{1+0.5 \cdot \varphi_{t}+2 \cdot \beta \cdot \sigma_{0}(z)} .
\end{aligned}
$$

1.3.3.1.3. Система канонічних рівнянь стадії тривалого навантаження паль на пружно-повзучій основі Вінклера

Система канонічних рівнянь при врахуванні повзучості основи за формою збігається з пружно-миттєвим рішенням: 


$$
A \cdot\left|\begin{array}{c}
X_{0}(t) \\
X_{1}(t) \\
\cdots \\
X_{n}(t) \\
\omega_{0}(t) \\
\varphi_{0}^{\prime}(t)
\end{array}\right|=\left|\begin{array}{c}
-\Delta_{0 p}(t) \\
-\Delta_{1 p}(t) \\
\cdots \\
-\Delta_{n p}(t) \\
\sum P \\
\sum M
\end{array}\right|,
$$

де А - квадратна матриця:

$$
A=\left|\begin{array}{cccccc}
\delta_{00}^{(t)} & \delta_{01} & \ldots & \delta_{0 n} & 1 & a_{0} \\
\delta_{10} & \delta_{11}^{(t)} & \ldots & \delta_{1 n} & 1 & a_{1} \\
\ldots & \ldots & \ldots & \ldots & \ldots & \ldots \\
\delta_{n 0} & \delta_{n 1} & \ldots & \delta_{n n}^{(t)} & 1 & a_{n} \\
1 & 1 & \ldots & 1 & 0 & 0 \\
a_{0} & a_{1} & \ldots & a_{n} & 0 & 0
\end{array}\right|,
$$

відзначимо, що отримуються з рішення системи (95) значення $\omega_{0}(t)$ i $\varphi_{0}^{\prime}(t)$ збільшені в $\frac{6 \cdot E I}{\lambda^{3}}$ раз.

Далі представимо запис одиничних переміщень $\delta_{k i}$ в різних випадках врахування лінійної і нелінійної повзучості основи.

Перш за все, відзначимо, що в будь-якому випадку

$$
\delta_{k i}=\overline{w_{k i}} \quad(k \neq i) .
$$

У разі визначення $\delta_{k k}(t)$ розглянемо різні варіанти диференціальних рівнянь.

а) Лінійна повзучість - рівняння (79).

У лівій частині рівняння використовується коефіцієнт постелі

$$
C_{t k}=\frac{C_{0}^{k}}{1+0.5 \cdot \varphi_{t}}
$$

при цьому одиничне переміщення $\delta_{k k}(t)$ одно

$$
\delta_{k k}(t)=\frac{1}{\lambda \cdot b \cdot C_{t k}}+w_{k k}=\frac{1+0.5 \cdot \varphi_{t}}{\lambda \cdot b \cdot C_{0}^{k}}+\frac{\lambda^{3}}{6 \cdot E I} \cdot \overline{w_{k k}},
$$

що приводиться до вигляду 


$$
\delta_{k k}(t)=\frac{\lambda^{3}}{6 \cdot E I} \cdot\left[\gamma_{k}^{0} \cdot\left(1+0.5 \cdot \varphi_{t}\right)+\overline{w_{k k}}\right]
$$

де $\gamma_{k}^{0}$ визначається за формулою (15).

б) Нелінійна повзучість - рівняння (80).

Аналогічним шляхом неважко знайти

$$
\delta_{k k}(t)=\frac{\lambda^{3}}{6 \cdot E I} \cdot\left[\gamma_{k}^{0} \cdot\left(1+\frac{\varphi_{t}}{2}+\frac{\beta \cdot \varphi_{t}}{b \cdot \lambda} \cdot X_{k}^{0}\right)+\overline{w_{k k}}\right] .
$$

в) При використанні рівняння (81) нелінійної повзучості таким же шляхом отримаємо

$$
\delta_{k k}(t)=\frac{\lambda^{3}}{6 \cdot E I} \cdot\left[\gamma_{k}^{0} \cdot\left(1+\frac{\beta \cdot \varphi_{t}}{b \cdot \lambda} \cdot X_{k}^{0}\right)+\overline{w_{k k}}\right] .
$$

1.3.3.1.4. Графічне представлення алгебраїчних реологічних рівнянь деформування Вінклерової основи конструкцій

Вище була використана алгебраїчна форма реологічних рівнянь лінійної і нелінійної повзучості теорії «старіння» (75), (76) і (77), отримана в роботі [45] при описі затухаючого зростання, або падіння контактних напружень $\sigma_{\tau}$ залежностями виду

$$
\left.\begin{array}{l}
\text { а) } \sigma_{\tau}=\sigma_{0} \pm \rho \cdot \varphi_{\tau} \\
\text { б) } \sigma_{\tau}=\frac{\sigma_{0}}{1 \pm \rho \cdot \varphi_{\tau}} .
\end{array}\right\} \text {. }
$$

Так як при врахуванні повзучості матеріалів вводиться координата часу $\tau$ , від якої залежить характеристика повзучості $\varphi_{\tau}$, осадка $V_{\tau}$ і напруги $\sigma_{\tau}$ в окремих точках контакту, то становить інтерес графічний вигляд різних варіантів алгебраїчних реологічних рівнянь, прийнятих в даній роботі.

Так на Мал. 25 показано графічно рівняння (76), яке описує затухаюче зростання контактних напружень при врахуванні нелінійної повзучості Вінклерової основи при функції нелінійності $f(\sigma)=\beta \cdot \sigma^{2}$. 
Прийняття трьох координатних осей $\sigma_{\tau}, V_{\tau} \mathrm{i} \tau$ дозволило простежити одночасно за розвитком осадок при згасаючому зростанні напруги $\sigma_{\tau} \mathrm{i}$ за зміною самих контактних напружень в часі $\tau$.

На Мал. 26 і 27 представлені графіки затухаючого зростання і затухаючого падіння контактних напружень в деяких точках Вінклерової основи при врахуванні лінійної повзучості по залежності (77).

Так як ця залежність містить два члена, перший з яких містить осадку основи $V_{\tau}$ і характеристику повзучості $\varphi_{\tau}$, а другий член формули (77) залежить тільки від початкової пружно-миттєвої напруги $\sigma_{0} \mathrm{i}$ характеристики $\varphi_{\tau}$, то представлені графіки містять в пунктирному вигляді (криві $\sigma_{\tau}-\tau$ i $\sigma_{\tau}-V_{\tau}$ ) додаткові відомості про зміну $\sigma_{\tau}$ без урахування другого члена формули (77).

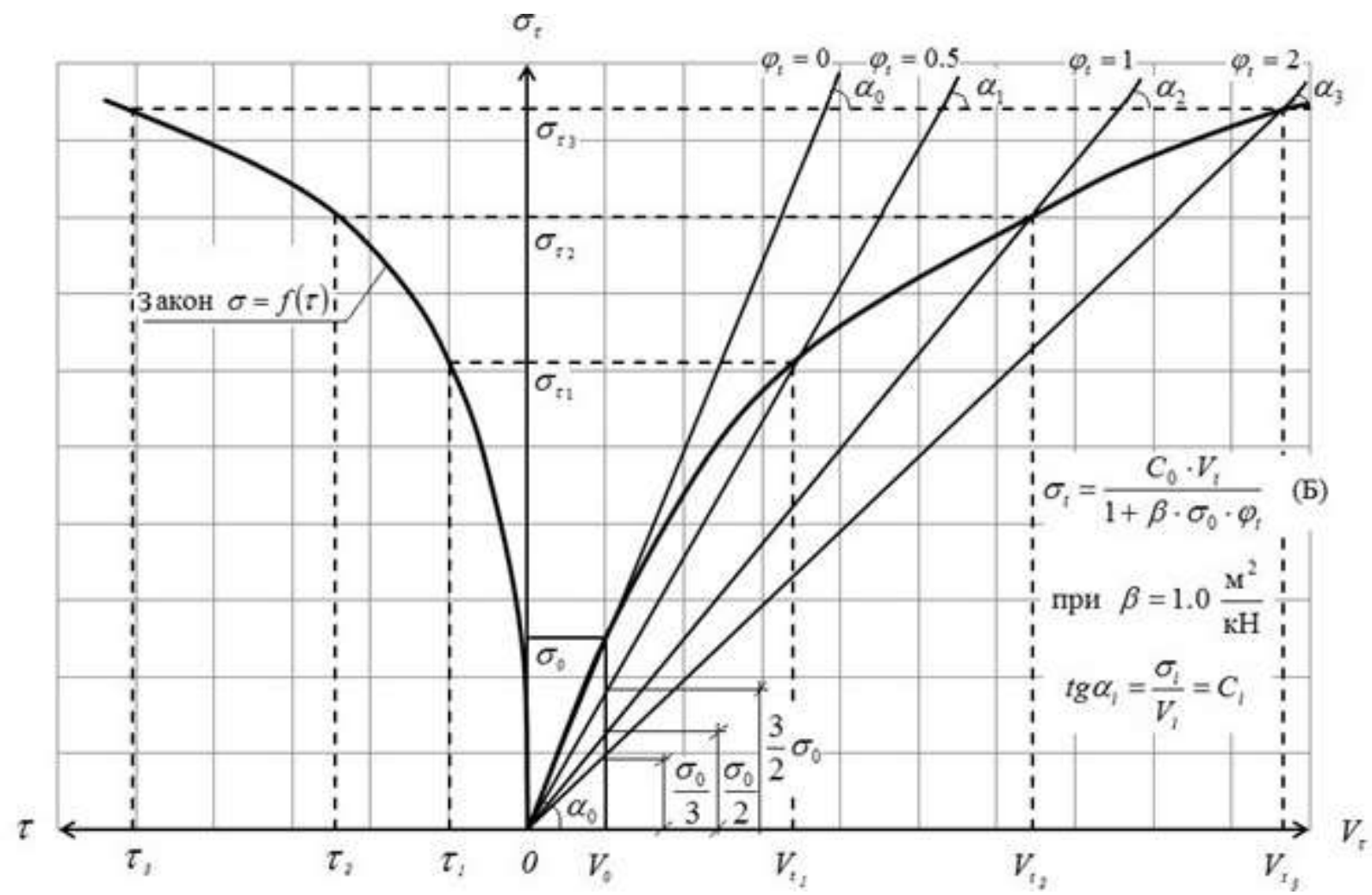

Малюнок 25. Графіки функцій, що відображують згасаюче зростання контактних напружень при нелінійній повзучості основи Вінклера (Б) 


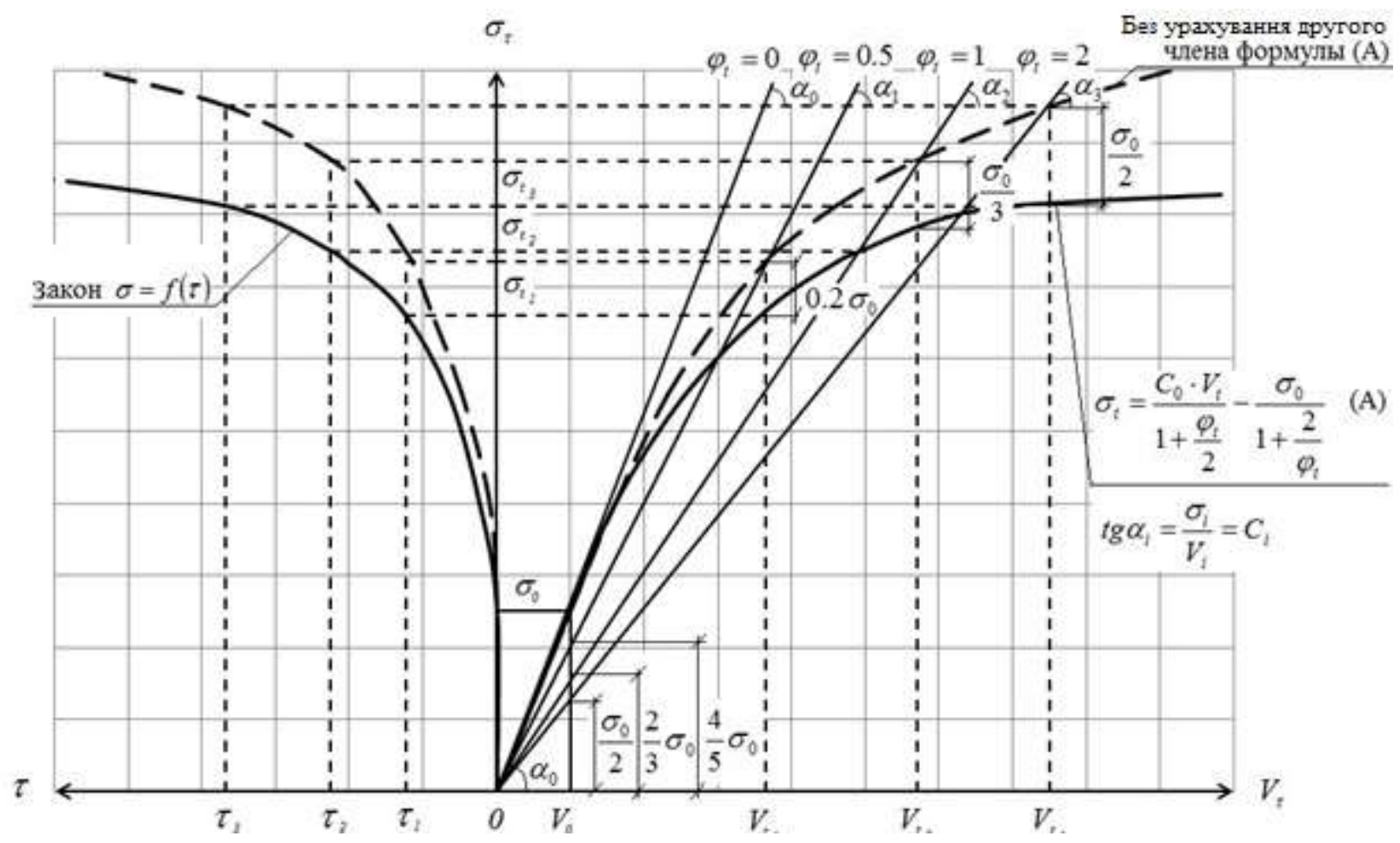

Малюнок 26. Графіки функцій, що відображують загасаюче зростання контактних напружень при лінійної повзучості основи Вінклера (А)

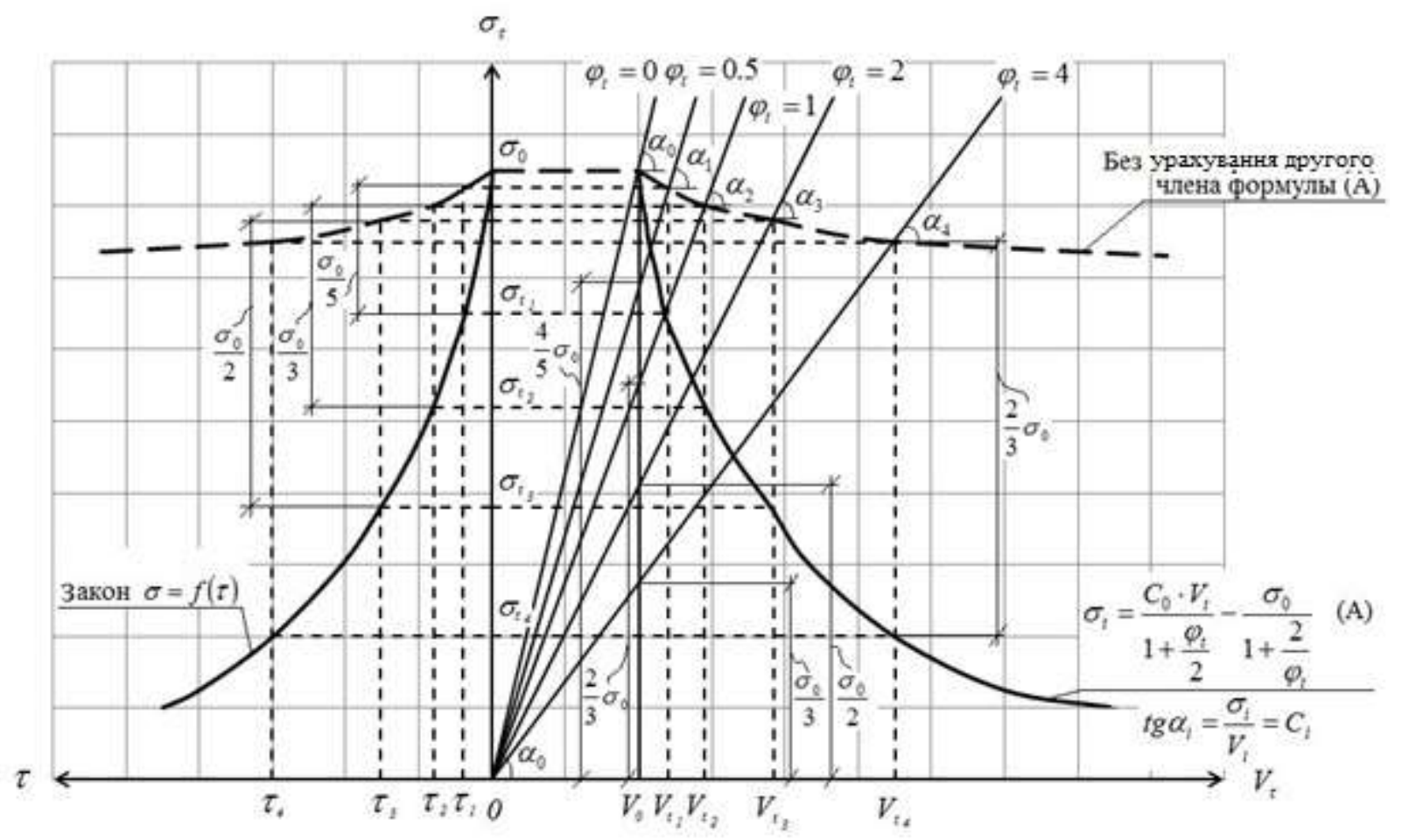

Малюнок 27. Графіки функцій, що відображують згасаюче падіння контактних напружень при лінійної повзучості основи Вінклера (А) 
3 цих графіків видна істотна роль другого члена в розвитку напруженодеформованого стану палі, зануреної в пружно-повзучу основу.

Як було показано раніше в розділі 3.1 .2 [формули (83), (84)] урахування другого члена реологичного рівняння приводить до появи додаткового навантаження $g_{t}(z)$, що впливає на розвиток деформації в часі.

1.3.3.2 Розрахунок горизонтально навантажених паль, затиснених в ростверк, з урахуванням тривалості деформування

Стосовно до загальноприйнятої моделі основи 3 лінійно зростаючим пружно-миттєвим коефіцієнтом постелі $C_{0}{ }^{2}$, уявімо закон деформування грунту при тривалому завантаженні, використовуючи передумови теорії «старіння» у вигляді [45]

$$
y_{t}^{z}=\frac{\sigma_{t}^{z}}{C_{0}{ }^{z} \cdot b_{p}}+\frac{\left({\sigma_{0}}^{z}+\sigma_{t}^{z}\right)}{2 \cdot C_{0}{ }^{z} \cdot b_{p}} \varphi_{t},
$$

де

$$
C_{0}{ }^{z}=K \cdot z
$$

$\varphi_{t}$ - характеристика повзучості підстави;

$b_{p}$ - розрахункова ширина палі, м;

K - пружно-миттєвий коефіцієнт пропорційності, тс / M4;

$\sigma_{0}{ }^{z}, \sigma_{t}{ }^{z}$ - навантаження від палі на одиницю довжини підстави в довільний момент часу $\tau=(0, t), \mathrm{Tc} / \mathrm{M}^{2}$

Уявімо вихідне диференціальне рівняння вигину палі при тривалому навантаженні в такому вигляді

$$
E I \cdot \frac{\partial^{4} y_{t}^{z}}{\partial z^{4}}+\sigma_{t}^{z}=0
$$

потім з (101) знайдемо $\sigma_{t}^{z}$ :

$$
\sigma_{t}{ }^{z}=\frac{2 \cdot C_{0}{ }^{2} \cdot b_{p} \cdot y_{t}{ }^{2}-\sigma_{0}{ }^{2} \cdot \varphi_{t}}{2+\varphi_{t}}
$$


Підставивши (104) в (103), отримаємо вихідне рівняння вигину палі

$$
\frac{\partial^{4} y_{t}^{z}}{\partial z^{4}}+\frac{2 \cdot K \cdot b_{p}}{\left(2+\varphi_{t}\right) \cdot E I} \cdot z \cdot y_{t}{ }^{z}=\frac{\varphi_{t} \cdot b_{p}}{\left(2+\varphi_{t}\right) \cdot E I} \cdot \sigma_{0}{ }^{z} .
$$

Провівши заміну змінної, після ряду перетворень знайдемо

$$
\frac{\partial^{4} y_{t}^{\bar{z}}}{\partial \bar{z}^{-4}}+\overline{z_{t}} \cdot y_{t}^{\bar{z}}=\frac{\varphi_{t} \cdot \beta_{t}}{2 \cdot K \cdot b_{p}} \cdot \sigma_{0}^{\bar{z}},
$$

Де $\beta_{t}=\sqrt[5]{\frac{2 \cdot K \cdot b_{p}}{\left(2+\varphi_{t}\right) \cdot E I}} ; \overline{z_{t}}=\beta_{t} \cdot z$

Пружно-миттєве рішення для паль, затиснених в ростверк, відповідно до «Керівництва» [48], може бути отримано із загального випадку завантаження палі в рівні поверхні силою $Q^{0}$ і моментом $M^{0}$ при рівності нулю кута повороту $\varphi^{0}$ на початку координат.

Однак, в даному випадку, рішення при $t=0$ можна спростити.

Використовуючи рішення I.В. Урбана [54], при $\varphi^{0}=0$ отримаємо в пружній стадії

$$
\left.\begin{array}{c}
y^{z}=y^{0} \cdot A_{1}^{z}+\frac{M^{0}}{\beta_{0}^{2} \cdot E I} \cdot C_{1}^{z}+\frac{Q^{0}}{\beta_{0}^{3} \cdot E I} \cdot D_{1}^{z} ; \\
-\frac{\varphi^{z}}{\beta_{0}}=y^{0} \cdot A_{2}^{z}+\frac{M^{0}}{\beta_{0}^{2} \cdot E I} \cdot C_{2}^{z}+\frac{Q^{0}}{\beta_{0}^{3} \cdot E I} \cdot D_{2}^{z} ; \\
\frac{M^{z}}{\beta_{0}^{2} \cdot E I}=y^{0} \cdot A_{3}^{z}+\frac{M^{0}}{\beta_{0}^{2} \cdot E I} \cdot C_{3}^{z}+\frac{Q^{0}}{\beta_{0}^{3} \cdot E I} \cdot D_{3}^{z} ; \\
\frac{Q^{z}}{\beta_{0}^{3} \cdot E I}=y^{0} \cdot A_{4}^{z}+\frac{M^{0}}{\beta_{0}^{2} \cdot E I} \cdot C_{4}^{z}+\frac{Q^{0}}{\beta_{0}^{3} \cdot E I} \cdot D_{4}^{z}
\end{array}\right\} .
$$

Беручи для нижнього кінця палі умову $Q^{H}=0 ; M^{H}=0,3$ двох нижніх рівнянь (107) отримуємо

$$
\left.\begin{array}{l}
M^{0}=-\frac{Q^{0}}{\beta_{0}} \cdot V^{H} \\
y^{0}=\frac{Q^{0}}{\beta_{0}^{3} \cdot E I} \cdot T^{H}
\end{array}\right\},
$$


де $V^{H}, T^{H}$ - нові функції, які залежать від довжини палі $H$.

$$
\begin{aligned}
& V_{0}^{H}=\frac{A_{3}^{H} \cdot D_{4}^{H}-A_{4}^{H} \cdot D_{3}^{H}}{A_{3}^{H} \cdot C_{4}^{H}-A_{4}^{H} \cdot C_{3}^{H}} ; \\
& T_{0}^{H}=\frac{C_{3}^{H} \cdot D_{4}^{H}-C_{4}^{H} \cdot D_{3}^{H}}{A_{3}^{H} \cdot C_{4}^{H}-A_{4}^{H} \cdot C_{3}^{H}} .
\end{aligned} .
$$

Таким чином, з (108) маємо можливість знайти $M^{\max }=M^{0}$ i $y^{\max }=y^{0}$, а $\varphi^{0}=0$ і $Q^{\max }=Q^{0}$ задані як основні параметри.

Далі з системи (107) і (108) знайдемо величини деформацій і зусиль в пружній стадії

$$
\left.\begin{array}{rl}
y^{z} & =\frac{Q^{0}}{\beta_{0}^{3} \cdot E I} \cdot\left(A_{1}^{z} \cdot T_{0}^{H}-C_{1}^{z} \cdot V_{0}^{H}+D_{1}^{z}\right) ; \\
-\varphi^{z} & =\frac{Q^{0}}{\beta_{0}^{2} \cdot E I} \cdot\left(A_{2}^{z} \cdot T_{0}^{H}-C_{2}^{z} \cdot V_{0}^{H}+D_{2}^{z}\right) ; \\
M^{z} & =\frac{Q^{0}}{\beta_{0}} \cdot\left(A_{3}^{z} \cdot T_{0}^{H}-C_{3}^{z} \cdot V_{0}^{H}+D_{3}^{z}\right) ; \\
Q^{z} & =Q^{0} \cdot\left(A_{4}^{z} \cdot T_{0}^{H}-C_{4}^{z} \cdot V_{0}^{H}+D_{4}^{z}\right) .
\end{array}\right\} .
$$

Тоді розподіл контактних напружень в пружній стадії, відповідно до закономірністі (102) і рішенню (110), визначається залежністю

$$
\sigma_{0}{ }^{z}=\beta_{0} \cdot \bar{z} \cdot Q^{0} \cdot\left(A_{1}^{z} \cdot T^{H}-C_{1}^{z} \cdot V^{H}+D_{1}^{z}\right),
$$

де $\beta_{0}=\sqrt[5]{\frac{K \cdot b_{p}}{E I}}, \bar{z}=\beta_{0} \cdot z$.

Відповідно до виразум (111) вихідне диференціальне рівняння (106) отримає такий вид

$$
\frac{\partial^{4} y(\bar{z}, t)}{\partial \bar{z}^{-4}}+\bar{z}_{t} y_{t}{ }^{x}=\frac{\varphi_{t}}{2 K \cdot b_{p}} \beta_{0} \beta_{t} \cdot \bar{z} \cdot Q_{0}\left(A_{1}^{z} \cdot T^{H}-C_{1}^{z} \cdot V^{H}+D_{1}^{z}\right) .
$$

Рішенням цього рівняння є сума часткового рішення «и» і спільного рішення «S».

Часткове рішення шукаємо у вигляді

$$
u=r_{1} \cdot A_{1}^{0}+r_{2} \cdot C_{1}^{0}+r_{3} \cdot D_{1}^{0} .
$$


Диференціюючи (113), отримуємо

$$
\frac{\partial^{4} u}{\partial z^{4}}=r_{1} \cdot\left(A_{1}^{0}\right)^{I V}+r_{2} \cdot\left(C_{1}^{0}\right)^{I V}+r_{3} \cdot\left(D_{1}^{0}\right)^{I V} .
$$

Використовуючи функції І.В. Урбана [54], можна показати, що існує співвідношення:

$$
\frac{\partial^{4} u}{\partial z^{4}}=-\beta_{0} \cdot z \cdot\left(r_{1} \cdot A_{1}^{0}+r_{2} \cdot C_{1}^{0}+r_{3} \cdot D_{1}^{0}\right),
$$

а 3 використанням часткового рішення (113), рівняння (112) набуває наступну форму

$$
\left(\beta_{t}-\beta_{0}\right)\left(r_{1} \cdot A_{1}^{0}+r_{2} \cdot C_{1}^{0}+r_{3} \cdot D_{1}^{0}\right)=\frac{\varphi_{t}}{2 K \cdot b_{p}} \beta_{0}^{2} \cdot \beta_{t} \cdot Q_{0}\left(A_{1}^{0} \cdot T^{H}-C_{1}^{0} \cdot V^{H}+D_{1}^{0}\right) .
$$

Прирівнюючи коефіцієнти при функціях початкового навантаження $A_{1}^{0}$, $C_{1}^{0}$ і $D_{1}^{0}$, знайдемо значення коефіцієнтів $r_{i}$, а потім і часткове рішення

$$
u=\frac{\varphi_{t}}{2 \cdot K \cdot b_{p}} \cdot \frac{\beta_{0}^{2} \cdot \beta_{t}}{\left(\beta_{t}-\beta_{0}\right)} \cdot Q_{0} \cdot\left(A_{1}^{0} \cdot T^{H}-C_{1}^{0} \cdot V^{H}+D_{1}^{0}\right) .
$$

Далі запишемо спільне рішення однорідного рівняння (112) (без правої частини) у вигляді

$$
s=N_{1} \cdot A_{1}^{t}+N_{2} \cdot C_{1}^{t}+N_{3} \cdot D_{1}^{t} .
$$

На основі (117) і (118) запишемо рівняння (106)

$$
y(\bar{z}, t)=N_{1} A_{1}^{t}+N_{2} C_{1}^{t}+N_{3} D_{1}^{t}+\frac{\varphi_{t} \cdot \beta_{0}^{2} \cdot \beta_{t}}{2 K \cdot b_{p}\left(\beta_{t}-\beta_{0}\right)} \cdot Q^{0} \cdot\left(A_{1}^{0} T^{H}-C_{1}^{0} V^{H}+D_{1}^{0}\right) .
$$

Довільні постійні отримаємо, використовуючи граничні умови

при $z=0: \quad y^{\prime}(0, t)=0 ; y^{\prime \prime \prime}(0, t)=\frac{Q^{0}}{E I} ;$

при $z=H: y^{\prime \prime}(H, t)=0 ; y^{\prime \prime \prime}(H, t)=0$.

При цьому врахуємо, що: $A_{2}=A_{1}^{\prime} ; A_{3}=A_{2}^{\prime} ; A_{4}=A_{3}^{\prime} ; B_{2}=B_{1}^{\prime} ; \ldots ; D_{4}=D_{3}^{\prime}$. 
Відомо, що функції І.В. Урбана при z = 0 дорівнюють нулю, крім чотирьох, які дорівнюють одиниці: $A_{1}(0)=B_{2}(0)=C_{3}(0)=D_{4}(0)=1$.

Далі, диференціюючи рівняння (119) і використовуючи граничні умови, отримаємо систему рівнянь для визначення $N_{i}$.

При відсутності повороту в місці защемлення палі в ростверк умова $y^{\prime}(0, t)=0$ задовольняється автоматично.

з умови $y^{\prime \prime \prime}(0, t)=\frac{Q^{0}}{E I}$ знаходимо $\beta_{t}^{3} \cdot N_{3}+\frac{\varphi_{t} \cdot \beta_{0}^{5} \cdot \beta_{t}}{2 \cdot K \cdot b_{p} \cdot\left(\beta_{t}-\beta_{0}\right)} \cdot Q^{0}=\frac{Q^{0}}{E I}$,

звідси

$$
N_{3}=\frac{Q^{0}}{\beta_{t}^{3} \cdot E I} \cdot\left[1+\frac{\varphi_{t} \cdot \beta_{t}}{2 \cdot\left(\beta_{0}-\beta_{t}\right)}\right] .
$$

Далі, використовуючи умови роботи нижнього кінця палі, отримаємо 3 (119) систему рівнянь $з$ двома невідомими $N_{1}$ і $N_{2}$

$$
\left.\begin{array}{rl}
N_{1} \cdot A_{3_{t}}^{H}+N_{2} \cdot C_{3_{t}}^{H}= & \frac{\varphi_{t}}{2 \cdot \beta_{0} \cdot \beta_{t} \cdot\left(\beta_{0}-\beta_{t}\right) \cdot E I} \cdot Q^{0} \cdot\left(A_{3_{0}}^{H} \cdot T_{0}^{H}-\right. \\
& \left.-C_{3_{0}}^{H} \cdot V_{0}^{H}+D_{3_{0}}^{H}\right)-N_{3} \cdot D_{3_{t}}^{H} ; \\
N_{1} \cdot A_{4_{t}}^{H}+N_{2} \cdot C_{4_{t}}^{H}= & \frac{\varphi_{t}}{2 \cdot \beta_{t}^{2} \cdot\left(\beta_{0}-\beta_{t}\right) \cdot E I} \cdot Q^{0} \cdot\left(A_{4_{0}}^{H} \cdot T_{0}^{H}-\right. \\
& \left.-C_{4_{0}}^{H} \cdot V_{0}^{H}+D_{4_{0}}^{H}\right)-N_{3} \cdot D_{4_{t}}^{H} .
\end{array}\right\} .
$$

Звернемо увагу на те, що відповідно до рішення (110), при $z=H$ функції, що стоять в дужках системи рівнянь (121), звертаються в нуль, а система спрощується до виду

$$
\left.\begin{array}{l}
N_{1} \cdot A_{3_{t}}^{H}+N_{2} \cdot C_{3_{t}}^{H}=-N_{3} \cdot D_{3_{t}}^{H} ; \\
N_{1} \cdot A_{4_{t}}^{H}+N_{2} \cdot C_{4_{t}}^{H}=-N_{3} \cdot D_{4_{t}}^{H} \cdot{ }^{H}
\end{array}\right\} .
$$

Це дозволяє, з урахуванням (120), знайти довільні постійні $N_{1}$ і $N_{2}$

$$
\left.\begin{array}{l}
N_{1}=\frac{\left(D_{4_{t}}^{H} \cdot C_{3_{t}}^{H}-D_{3_{t}}^{H} \cdot C_{4_{t}}^{H}\right)}{\left(A_{3_{t}}^{H} \cdot C_{4_{t}}^{H}-A_{4_{t}}^{H} \cdot C_{3_{t}}^{H}\right)} \cdot \frac{Q^{0}}{\beta_{t}^{3} \cdot E I} \cdot\left[1+\frac{\varphi_{t}}{2 \cdot(\lambda-1)}\right] ; \\
N_{2}=\frac{\left(D_{3_{t}}^{H} \cdot A_{4_{t}}^{H}-D_{4_{t}}^{H} \cdot A_{3_{t}}^{H}\right)}{\left(A_{3_{t}}^{H} \cdot C_{4_{t}}^{H}-A_{4_{t}}^{H} \cdot C_{3_{t}}^{H}\right)} \cdot \frac{Q^{0}}{\beta_{t}^{3} \cdot E I} \cdot\left[1+\frac{\varphi_{t}}{2 \cdot(\lambda-1)}\right],
\end{array}\right\},
$$


де $\lambda=\frac{\beta_{0}}{\beta_{t}}=\sqrt[5]{1+\frac{\varphi_{t}}{2}}$.

Відповідно до отриманого вище рішенням (109), (110), вирази для довільних постійних (120) спростяться і матимуть такий вигляд

$$
\left.\begin{array}{l}
N_{1}=\frac{Q^{0}}{\beta_{t}^{3} \cdot E I} \cdot T_{t}^{H} \cdot\left[1+\frac{\varphi_{t}}{2 \cdot(\lambda-1)}\right] ; \\
N_{2}=-\frac{Q^{0}}{\beta_{t}^{3} \cdot E I} \cdot V_{t}^{H} \cdot\left[1+\frac{\varphi_{t}}{2 \cdot(\lambda-1)}\right],
\end{array}\right\},
$$

де функції $T_{t}^{H}$ i $V_{t}^{H}$ визначаються за формулою (109) при $\beta=\beta_{t}$;

Використовуючи отримані перетворення, запишемо рішення рівняння (119) у вигляді:

$$
\begin{aligned}
y(z, t) & =\frac{Q^{0}}{\beta_{0}^{3} \cdot E I} \cdot\left\{\left[1+\frac{\varphi_{t}}{2 \cdot(\lambda-1)}\right] \cdot\left(A_{1_{t}}^{z} \cdot T_{t}^{H}-C_{1_{t}}^{z} \cdot V_{t}^{H}+D_{1_{t}}^{z}\right) \cdot \lambda^{3}-\right. \\
& \left.-\frac{\varphi_{t}}{2 \cdot(\lambda-1)} \cdot\left(A_{1_{0}}^{z} \cdot T_{0}^{H}-C_{1_{0}}^{z} \cdot V_{0}^{H}+D_{1_{0}}^{z}\right)\right\} .
\end{aligned}
$$

3 (125) можна отримати максимальні переміщення при $z=0$.

$$
y(0, t)=\frac{Q^{0}}{\beta_{0}^{3} \cdot E I} \cdot\left\{\left[1+\frac{\varphi_{t}}{2 \cdot(\lambda-1)}\right] \cdot \lambda^{3} \cdot T_{t}^{H}-\frac{\varphi_{t}}{2 \cdot(\lambda-1)} \cdot T_{0}^{H}\right\} .
$$

3 огляду на те, що значення функцій $T_{0}^{H}$ i $T_{t}^{H}$ відрізняються незначно, приблизно можемо записати через $T_{c p}=\frac{T_{0}^{H}+T_{t}^{H}}{2}$ :

$$
y(0, t) \approx \frac{Q^{0}}{\beta_{0}^{3} \cdot E I} \cdot T_{c p}^{H} \cdot\left[\lambda^{3}+\frac{\varphi_{t}}{2} \cdot\left(\lambda^{2}+\lambda+1\right)\right],
$$

тобто рішення з урахуванням лінійної повзучості основи виходить шляхом множення результату пружно-миттєвого вирішення на коефіцієнт, що враховує реологічні властивості основи.

Взявши послідовно похідні виразу (125), неважко отримати значення $\varphi(z, t), M(z, t)$ i $Q(z, t)$ 


$$
\begin{aligned}
-\varphi(z, t) & =\frac{Q^{0}}{\beta_{0}^{2} \cdot E I} \cdot\left\{\left[1+\frac{\varphi_{t}}{2 \cdot(\lambda-1)}\right] \cdot\left(A_{2_{t}}^{z} \cdot T_{t}^{H}-C_{2_{t}}^{z} \cdot V_{t}^{H}+D_{2_{t}}^{z}\right) \cdot \lambda^{2}-\right. \\
& \left.-\frac{\varphi_{t}}{2 \cdot(\lambda-1)} \cdot\left(A_{2_{0}}^{z} \cdot T_{0}^{H}-C_{2_{0}}^{z} \cdot V_{0}^{H}+D_{2_{0}}^{z}\right)\right\} ; \\
M(z, t)= & \frac{Q^{0}}{\beta_{0}} \cdot\left\{\left[1+\frac{\varphi_{t}}{2 \cdot(\lambda-1)}\right] \cdot\left(A_{3_{t}}^{z} \cdot T_{t}^{H}-C_{3_{t}}^{z} \cdot V_{t}^{H}+D_{3_{t}}^{z}\right) \cdot \lambda-\right. \\
& \left.-\frac{\varphi_{t}}{2 \cdot(\lambda-1)} \cdot\left(A_{3_{0}}^{z} \cdot T_{0}^{H}-C_{3_{0}}^{z} \cdot V_{0}^{H}+D_{3_{0}}^{z}\right)\right\} ; \\
Q(z, t)= & \frac{Q^{0}}{\beta_{0}} \cdot\left\{\left[1+\frac{\varphi_{t}}{2 \cdot(\lambda-1)}\right] \cdot\left(A_{4_{t}}^{z} \cdot T_{t}^{H}-C_{4_{t}}^{z} \cdot V_{t}^{H}+D_{4_{t}}^{z}\right)-\right. \\
& \left.-\frac{\varphi_{t}}{2 \cdot(\lambda-1)} \cdot\left(A_{4_{0}}^{z} \cdot T_{0}^{H}-C_{4_{0}}^{z} \cdot V_{0}^{H}+D_{4_{0}}^{z}\right)\right\} .
\end{aligned}
$$

Встановимо зміни в часі згинального моменту в місці защемлення палі в ростверк. Якщо врахувати, що величини $V_{0}^{H}$ i $V_{t}^{H}$ практично рівні, то взявши їх середнє значення $V_{c p}^{H}$ нескладно отримати з (128)

$$
-M(0, t) \approx \frac{Q^{0}}{\beta_{0}} \cdot V_{c p}^{H} \cdot\left(\lambda+\frac{\varphi_{t}}{2}\right) .
$$

Більш точно отримаємо 3 (128)

$$
-M(0, t)=\frac{Q^{0}}{\beta_{0}} \cdot\left[\left(1+\frac{\varphi_{t}}{2 \cdot(\lambda-1)}\right) \cdot \lambda \cdot V_{t}^{H}-\frac{\varphi_{t}}{2 \cdot(\lambda-1)} \cdot V_{0}^{H}\right] .
$$

Що ж стосується величин $\varphi(0, t)$ і $Q(0, t)$, то неважко з рішення (128) помітити, що вони не схильні до впливу повзучості основи, тобто

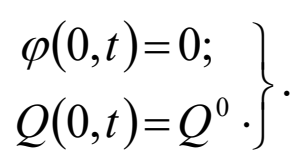

Крім того, якщо використовувати отримане вище спрощення при $T^{H}=V^{H}=S^{H}$, то істотно спроститься і рішення 3 урахуванням повзучості основи 


$$
\begin{aligned}
y(z, t)= & \frac{Q^{0}}{\beta_{0}^{3} \cdot E I} \cdot\left\{\left[1+\frac{\varphi_{t}}{2 \cdot(\lambda-1)}\right] \cdot\left(R_{1_{t}}^{z} \cdot S^{H}+D_{1_{t}}^{z}\right) \cdot \lambda^{3}-\right. \\
& \left.-\frac{\varphi_{t}}{2 \cdot(\lambda-1)} \cdot\left(R_{1_{0}}^{z} \cdot S^{H}+D_{1_{0}}^{z}\right)\right\} ; \\
-\varphi(z, t)= & \frac{Q^{0}}{\beta_{0}^{2} \cdot E I} \cdot\left\{\left[1+\frac{\varphi_{t}}{2 \cdot(\lambda-1)}\right] \cdot\left(R_{2_{t}}^{z} \cdot S^{H}+D_{2_{t}}^{z}\right) \cdot \lambda^{2}-\right. \\
& \left.-\frac{\varphi_{t}}{2 \cdot(\lambda-1)} \cdot\left(R_{2_{0}}^{z} \cdot S^{H}+D_{2_{0}}^{z}\right)\right\} ; \\
M(z, t)= & \frac{Q^{0}}{\beta_{0} \cdot E I} \cdot\left\{\left[1+\frac{\varphi_{t}}{2 \cdot(\lambda-1)}\right] \cdot\left(R_{3_{t}}^{z} \cdot S^{H}+D_{3_{t}}^{z}\right) \cdot \lambda-\right. \\
& \left.-\frac{\varphi_{t}}{2 \cdot(\lambda-1)} \cdot\left(R_{3_{0}}^{z} \cdot S^{H}+D_{3_{0}}^{z}\right)\right\} ; \\
Q(z, t)= & Q^{0} \cdot\left\{\left[1+\frac{\varphi_{t}}{2 \cdot(\lambda-1)}\right] \cdot\left(R_{4_{t}}^{z} \cdot S^{H}+D_{4_{t}}^{z}\right)-\right. \\
& \left.-\frac{\varphi_{t}}{2 \cdot(\lambda-1)} \cdot\left(R_{4_{0}}^{z} \cdot S^{H}+D_{4_{0}}^{z}\right)\right\} \cdot
\end{aligned}
$$

\section{Приклад розрахунку 6}

Оцінимо вплив повзучості основи на величини згинальних моментів, поперечних сил, горизонтальних переміщень і кутів повороту в перетинах палі, затисненої в ростверк, завантаженої горизонтальної силою у поверхні грунту $Q^{0}=10$ тс, за таких умов:

$E I=6.2 \cdot 103 \mathrm{тc} \cdot \mathrm{m}^{2} ; \mathrm{b}=0.4 \mathrm{~m} ; \mathrm{H}=6 \mathrm{~m} ;$ розрахункова ширина палі $b_{p}=1.1_{\mathrm{M}}$. Грунт характеризується коефіцієнтом пропорційності: $К=700 \mathrm{Tc} / \mathrm{M}^{4}$.

Розглянемо рішення при декількох значеннь характеристики повзучості: $\varphi_{t}=0 \div 3$.

1. Обчислюємо коефіцієнти деформації пружно-миттєвого і тривалого завантаження

$$
\beta_{0}=\sqrt[5]{\frac{K \cdot b_{p}}{E I}}=\sqrt[5]{\frac{700 \cdot 1.1}{6.2 \cdot 10^{3}}}=\sqrt[5]{0.1242}=0.6589 \mathrm{M}^{-1} .
$$


підставляючи в $\beta_{t}=\sqrt[5]{\frac{2 \cdot K \cdot b_{p}}{\left(2+\varphi_{t}\right) \cdot E I}}$ характеристики повзучості $\varphi_{t}=0 ; 1 ; 2 ; 3$, Відповідно визначимо $\beta_{t}=0.6589 ; 0.6076 ; 0.6736 ; 0.5486$; а зі співвідношення $\lambda=\frac{\beta_{0}}{\beta_{t}}$ відповідно отримаємо: $1 ; 1.09 ; 1.15 ; 1$.

Пружно-миттєве переміщення голови палі.

По (119) і (118) при $H_{0}=\beta_{0} \cdot H \approx 4$ :

$$
\begin{gathered}
T_{0}^{H}=\frac{C_{3}^{H} \cdot D_{4}^{H}-C_{4}^{H} \cdot D_{3}^{H}}{A_{3}^{H} \cdot C_{4}^{H}-A_{4}^{H} \cdot C_{3}^{H}}=0.9396 ; \\
V_{0}^{H}=\frac{A_{3}^{H} \cdot D_{4}^{H}-A_{4}^{H} \cdot D_{3}^{H}}{A_{3}^{H} \cdot C_{4}^{H}-A_{4}^{H} \cdot C_{3}^{H}}=0.9260 ; \\
y^{0}=\frac{Q^{0}}{\beta_{0}^{3} \cdot E I} \cdot T^{H}=\frac{10}{0.6589^{3} \cdot 6.2 \cdot 10^{3}} \cdot 0.9396=0.5298 \cdot 10^{-2} \mathrm{M} ; \\
M^{0}=-\frac{Q^{0}}{\beta_{0}} \cdot V^{H}=-\frac{10}{0.6589} \cdot 0.9260=-14.053 \mathrm{Tc} \cdot \mathrm{M} .
\end{gathered}
$$

3. Тривале навантаження (детальний розрахунок наведемо лише при характеристиці повзучості $\varphi_{t}=3$ ). Цікавим є порівняти результати точного $\mathrm{i}$ наближеного рішень.

a) Величину прогину отримаємо 3 (126), при $H_{t}=\beta_{t} \cdot H=3.5$ :

$$
\begin{aligned}
& T_{t}^{H}=\frac{62.81396}{64.7687}=0.97282 ; \\
& V_{t}^{H}=\frac{60.4747}{64.7687}=0.9337 ;
\end{aligned}
$$

$y(0, t)=\frac{10}{0.6589^{3} \cdot 6.2 \cdot 10^{3}} \cdot\left\{\left[1+\frac{3}{2 \cdot 0.2}\right] \cdot 1.2^{3} \cdot 0.96981-\frac{\varphi_{t}}{2 \cdot 0.2} \cdot 0.9396\right\}=0.04056 \mathrm{M}$.

За наближеною формулою (127) отримаємо близьке значення

$$
y(0, t)=\frac{10}{0.6589^{3} \cdot 6.2 \cdot 10^{3}} \cdot 0.9547 \cdot\left[1.2^{3}+\frac{3}{2} \cdot\left(1.2^{2}+1.2+1\right)\right]=0.0387 \mathrm{M} .
$$

б) Величину згинального моменту отримаємо з (131) 


$$
-M(0, t)=\frac{10}{0.6589} \cdot\left[\left(1+\frac{3}{2 \cdot 0.2}\right) \cdot 1.2 \cdot 0.9337-\frac{3}{2 \cdot 0.2} \cdot 0.926\right]=39.0997 \mathrm{Tc} \cdot \mathrm{M} .
$$

За наближеною формулою (142) отримаємо також близьке значення

$$
-M(0, t) \approx \frac{10}{0.6589} \cdot 0.92985 \cdot\left(1.2+\frac{3}{2}\right)=38.1028 \mathrm{Tc} \cdot \mathrm{M} .
$$

Графіки отриманих значень $y_{z}, \varphi_{z}, M_{z}$ i $Q_{z}$ в залежності від z при $\varphi_{t}=0 \div 3$ представлені на Мал. 28 .

4. Висновки:

- при обліку повзучості грунтового масиву переміщення $y_{0}$ зростають, при $\varphi_{t}=3$ в 4 рази;

- зі зростанням $\varphi_{t}$ максимальний згинальний момент в місці защемлення палі в ростверк зростає, при $\varphi_{t}=3$, Приблизно, в 2,5 рази.
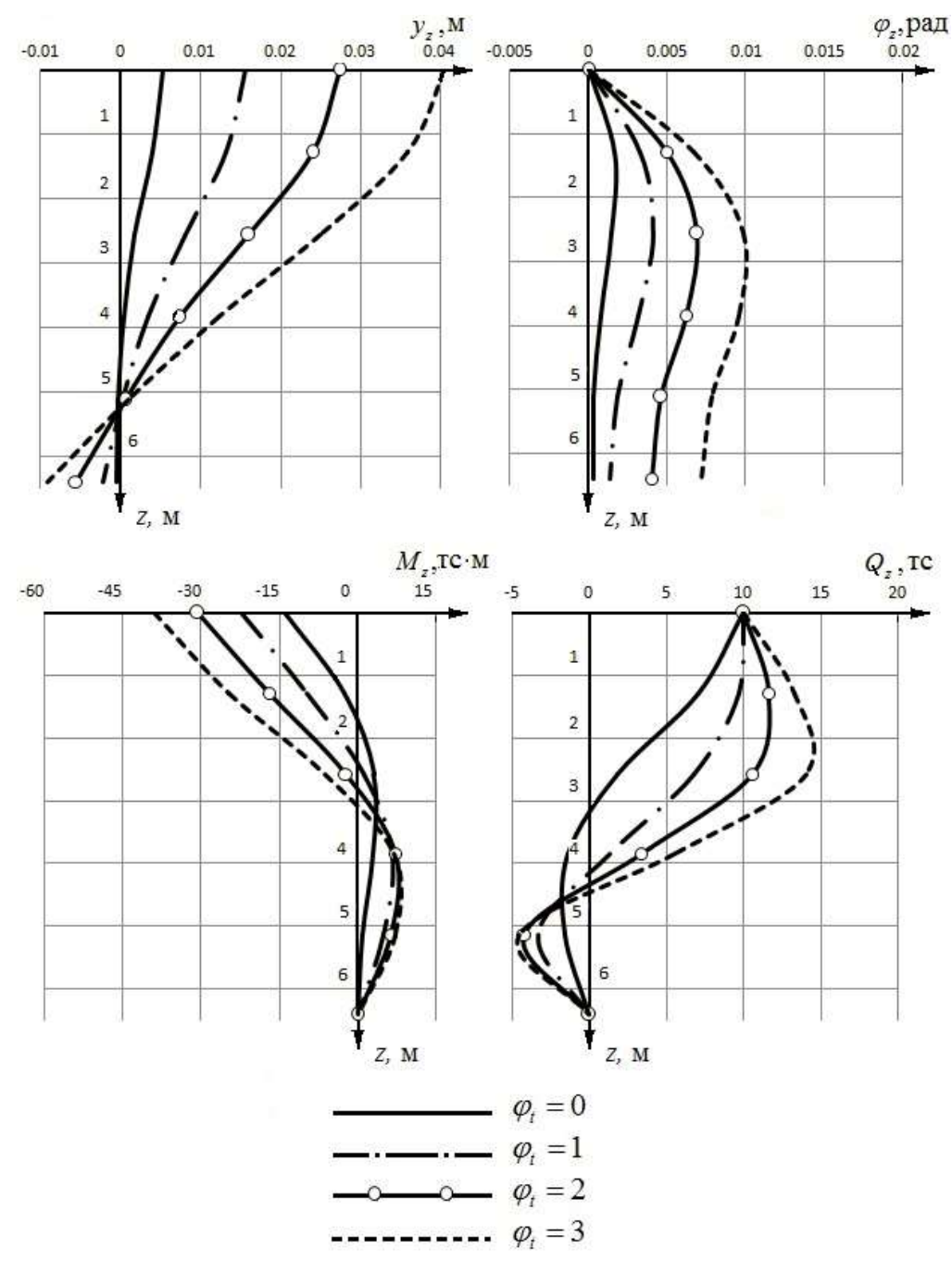

Малюнок 28. Епюри $y_{z}, \varphi_{z}, M_{z}$ i $Q_{z}$ прикладу розрахунку 6 
1.3.3.3 Розрахунок горизонтально навантажених паль, при наявності розпірки в рівні грунту, з урахуванням тривалого деформування

Такий варіант конструктивного рішення може виникнути, наприклад, при необхідності створення пальового (шпунтового) огорожі вузьких котлованів, при будівництві комунікаційних споруд і т.п. [55] (Мал. 29 а, б), при якому доводиться вирішувати завдання вигину палі під дією сили $Q_{0}$ i моменту $M_{0}$ в рівні розпірки (Мал. 30).

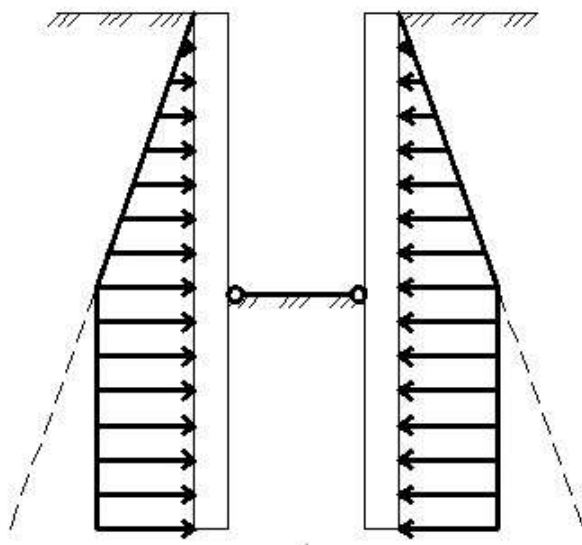

a)

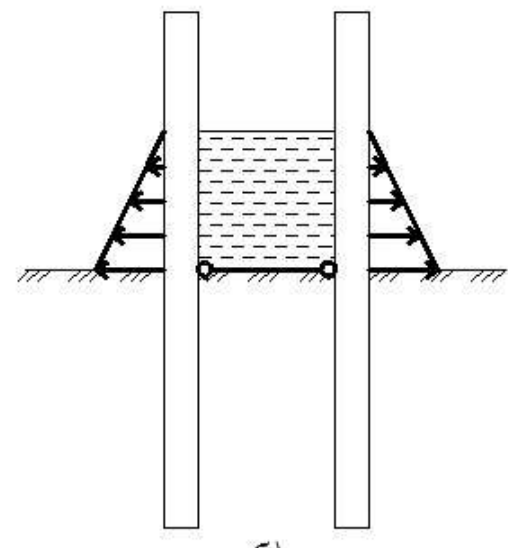

б)

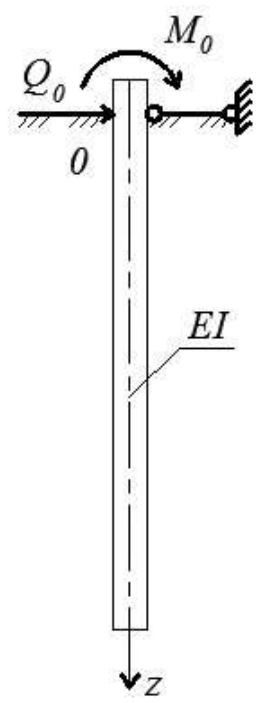

Малюнок 29 та 30. Розрахункові схеми поперечно завантаженої палі

\subsubsection{1. Пружньо-миттєва стадія}

Система рівнянь методу початкових параметрів для даної задачі (при $\left.y_{0}=0\right)$ В пружною стадії отримує такий вигляд

$$
\left.\begin{array}{rl}
y_{z} & =\frac{\varphi_{0}}{\beta_{0}} \cdot B_{1}{ }^{z}+\frac{M_{0}}{\beta_{0}^{2} \cdot E I} \cdot C_{1}{ }^{z}+\frac{Q_{0}}{\beta_{0}^{3} \cdot E I} \cdot D_{1}{ }^{z} ; \\
\frac{\varphi_{z}}{\beta} & =\frac{\varphi_{0}}{\beta_{0}} \cdot B_{2}{ }^{2}+\frac{M_{0}}{\beta_{0}^{2} \cdot E I} \cdot C_{2}{ }^{z}+\frac{Q_{0}}{\beta_{0}^{3} \cdot E I} \cdot D_{2}{ }^{z} ; \\
\frac{M_{z}}{\beta_{0}^{2} \cdot E I} & =\frac{\varphi_{0}}{\beta_{0}} \cdot B_{3}{ }^{z}+\frac{M_{0}}{\beta_{0}^{2} \cdot E I} \cdot C_{3}{ }^{z}+\frac{Q_{0}}{\beta_{0}^{3} \cdot E I} \cdot D_{3}{ }^{z} ; \\
\frac{Q_{z}}{\beta_{0}^{3} \cdot E I} & =\frac{\varphi_{0}}{\beta_{0}} \cdot B_{4}{ }^{2}+\frac{M_{0}}{\beta_{0}^{2} \cdot E I} \cdot C_{4}{ }^{z}+\frac{Q_{0}}{\beta_{0}^{3} \cdot E I} \cdot D_{4}{ }^{z}
\end{array}\right\},
$$


де $y_{z}, \varphi_{z}, M_{z}$ i $Q_{z}$ - горизонтальне переміщення, кут повороту, згинальний момент і поперечна сила відповідно в будь-якому поперечному перерізі палі з координатою перетину $\bar{z}=\beta_{0} \cdot z$.

Функції $B_{i}{ }^{z}, C_{i}{ }^{z}$ i $D_{i}{ }^{z}$ називають функціями впливу. Їх величини, які відповідають різним значенням наведеної глибини, поміщені в таблиці 1 [56].

Беручи на нижньому кінці палі умова $Q^{H}=0 ; M^{H}=0,3$ двох нижніх рівнянь (124) отримуємо

$$
\left.\begin{array}{l}
\beta_{0}^{2} \cdot E I \cdot \varphi_{0} \cdot B_{3}{ }^{H}+Q_{0} \cdot D_{3}{ }^{H}=-\beta_{0} \cdot M_{0} \cdot C_{3}{ }^{H} ; \\
\beta_{0}{ }^{2} \cdot E I \cdot \varphi_{0} \cdot B_{4}{ }^{H}+Q_{0} \cdot D_{4}{ }^{H}=-\beta_{0} \cdot M_{0} \cdot C_{4}{ }^{H}
\end{array}\right\} .
$$

Із системи (133) можна записати два невідомих початкових параметра в такому вигляді

$$
\left.\begin{array}{l}
\varphi_{0}=-\frac{M_{0}}{\beta_{0} \cdot E I} \cdot W^{H} ; \\
Q_{0}=-\beta_{0} \cdot M_{0} \cdot R^{H},
\end{array}\right\},
$$

де $W^{H}$ і $R^{H}$ - нові функції, які залежать від приведеної довжини палі Н (Мал. 31):

$$
\left.\begin{array}{c}
W^{H}=\frac{C_{3}^{H} \cdot D_{4}^{H}-C_{4}^{H} \cdot D_{3}^{H}}{B_{3}^{H} \cdot D_{4}^{H}-B_{4}^{H} \cdot D_{3}^{H}} ; \\
R^{H}=\frac{B_{3}^{H} \cdot C_{4}^{H}-B_{4}^{H} \cdot C_{3}^{H}}{B_{3}^{H} \cdot D_{4}^{H}-B_{4}^{H} \cdot D_{3}^{H}},
\end{array}\right\} .
$$

Аналіз результатів розрахунків показав, що для широкого діапазону наведених довжин паль $2.6 \leq \beta_{0} \cdot H \leq 4$ з точністю в межах $(1 \div 1.3) \%$ можна прийняти (Мал. 31)

$$
\left.\begin{array}{l}
W_{c p}^{\prime} \approx-0,68 \\
R_{c p}^{\prime} \approx-0,656,
\end{array}\right\},
$$

а $з$ точністю до 5\% можна вважати, що

$$
W_{c p}^{\prime \prime}=R_{c p}^{\prime \prime}=-0,666
$$




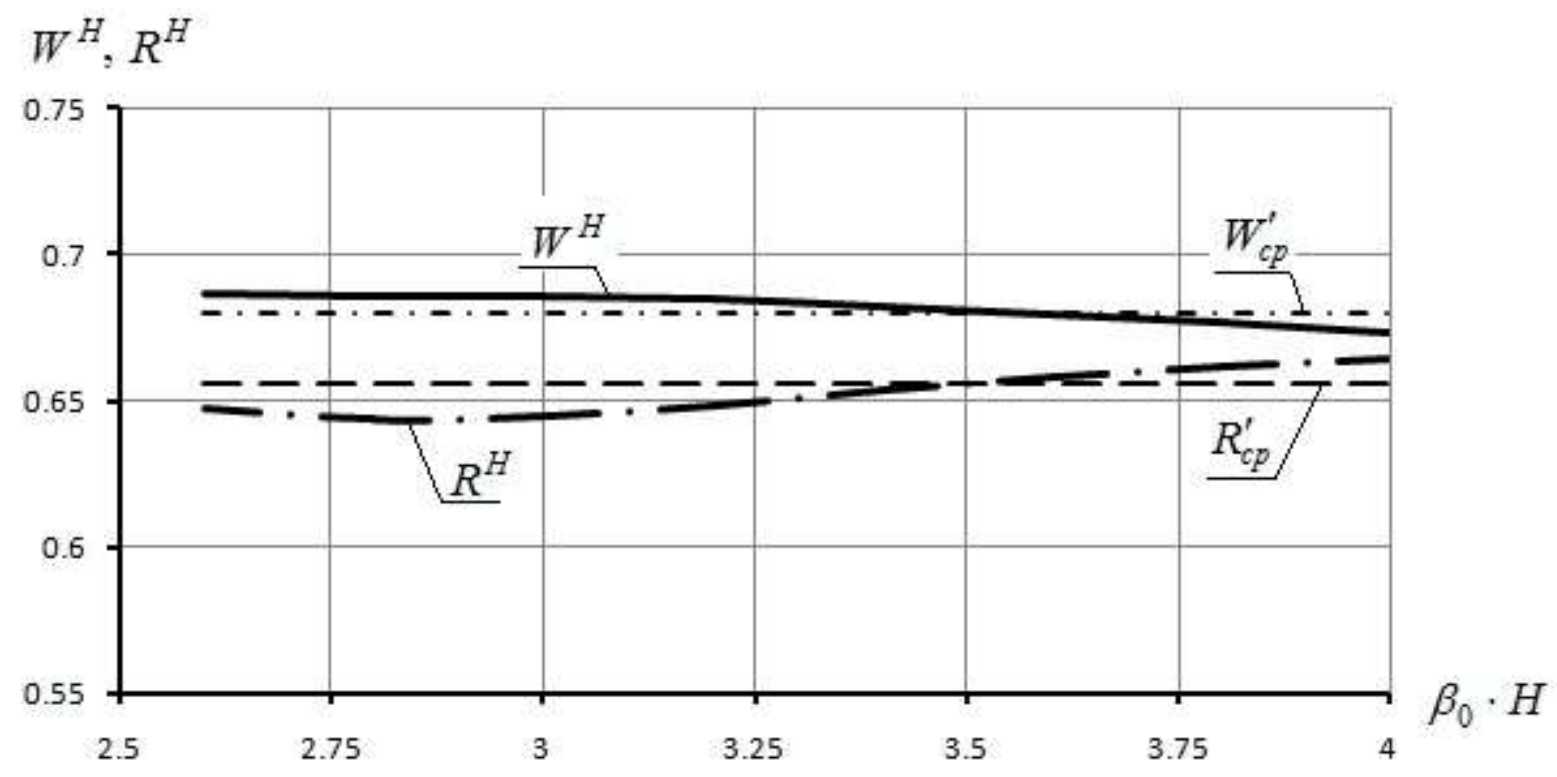

Малюнок 31. Функції $W^{H}$ i $R^{H}$ в залежності від приведеної довжини паль $\beta_{0} \cdot H$

Спочатку запишемо суворе рішення системи (132) з урахуванням (134) i (135):

$$
\begin{aligned}
& y_{z} \cong \frac{M_{0}}{\beta_{0}^{2} \cdot E I} \cdot\left(-B_{1}{ }^{z} \cdot W^{H}+C_{1}{ }^{z}-D_{1}{ }^{z} \cdot R^{H}\right) ; \\
& \varphi_{z} \cong \frac{M_{0}}{\beta_{0} \cdot E I} \cdot\left(-B_{2}{ }^{z} \cdot W^{H}+C_{2}{ }^{z}-D_{2}{ }^{z} \cdot R^{H}\right) ; \\
& M_{z} \cong M_{0} \cdot\left(-B_{3}{ }^{z} \cdot W^{H}+C_{3}{ }^{z}-D_{3}{ }^{z} \cdot R^{H}\right) ; \\
& Q_{z} \cong M_{0} \cdot \beta_{0} \cdot\left(-B_{4}{ }^{z} \cdot W^{H}+C_{4}{ }^{z}-D_{4}{ }^{z} \cdot R^{H}\right) .
\end{aligned} .
$$

Якщо прийняти наближені функції $W^{H}$ i $R^{H}$ по усереднення (136), то система рівнянь (138) перетворюється

$$
\left.\begin{array}{rl}
y_{z} & \cong \frac{M_{0}}{\beta_{0}^{2} \cdot E I} \cdot\left(-0.68 \cdot B_{1}^{z}+C_{1}^{z}-0.656 \cdot D_{1}^{z}\right) ; \\
\varphi_{z} & \cong \frac{M_{0}}{\beta_{0} \cdot E I} \cdot\left(-0.68 \cdot B_{2}{ }^{z}+C_{2}{ }^{z}-0.656 \cdot D_{2}{ }^{z}\right) ; \\
M_{z} & \cong M_{0} \cdot\left(-0.68 \cdot B_{3}{ }^{z}+C_{3}{ }^{z}-0.656 \cdot D_{3}{ }^{z}\right) ; \\
Q_{z} & \cong M_{0} \cdot \beta_{0} \cdot\left(-0.68 \cdot B_{4}{ }^{z}+C_{4}{ }^{z}-0.656 \cdot D_{4}{ }^{z}\right) .
\end{array}\right\} .
$$

3 метою спрощення цієї системи скористаємося рівністю (137) 


$$
\left.\begin{array}{l}
y_{z} \cong \frac{M_{0}}{\beta_{0}^{2} \cdot E I} \cdot U_{1}^{z} ; \\
\varphi_{z} \cong \frac{M_{0}}{\beta_{0} \cdot E I} \cdot U_{2}^{z} ; \\
M_{z} \cong M_{0} \cdot U_{3}^{z} ; \\
Q_{z} \cong M_{0} \cdot \beta_{0} \cdot U_{4}^{z}
\end{array}\right\},
$$

де прийняті наступні позначення:

$$
\left.\begin{array}{l}
U_{1}^{z} \cong-\frac{\left(B_{1}^{z}+D_{1}^{z}\right)}{1.5}+C_{1}^{z} ; \\
U_{2}^{z} \cong-\frac{\left(B_{2}^{z}+D_{2}^{z}\right)}{1.5}+C_{2}^{z} ; \\
U_{3}^{z} \cong-\frac{\left(B_{3}^{z}+D_{3}^{z}\right)}{1.5}+C_{3}^{z} ; \\
U_{4}^{z} \cong-\frac{\left(B_{4}^{z}+D_{4}^{z}\right)}{1.5}+C_{4}{ }^{z} \cdot
\end{array}\right\} .
$$

Для ілюстрації значущості пропонованого методу порівняємо результати розрахунків з використанням функцій відносних переміщень і зусиль для паль 3 вільною головою і з розпіркою в рівні поверхні грунту.

\section{Приклад розрахунку 7}

Знайдемо відносні переміщення i згинальні моменти, обчисливши значення функцій $U_{1}{ }^{z}, U_{2}{ }^{z}, U_{3}{ }^{z}$ і $U_{4}{ }^{z}$ в діапазоні $0 \leq \bar{z} \leq 4$, де $\bar{z}=\beta_{0} \cdot z$ наведена (безрозмірна) глибина поперечного перерізу палі.

У табл. 1 наведені величини $U_{i}{ }^{2}$.

Графіки отриманих значень $U_{i}{ }^{2}$ для паль 3 розпіркою (Мал. 32, а) представлені на Мал. 33. Пунктиром показані аналогічні графіки відносних переміщень і зусиль для паль без розпірок, з наведеної глибиною закладення $\bar{l}=4$, Завантажених изгибающим моментом в рівні поверхні грунту (Мал. 32, б). 
Таблиця 1.

Числові значення функцій $\boldsymbol{U}_{\boldsymbol{i}}{ }^{\boldsymbol{z}}$

\begin{tabular}{|l|l|l|l|l|l|l|l|l|l|l|}
\hline & & .4 & 1.2 & 6 & 0 & 4 & 8 & 3.0 & .5 & .0 \\
\hline & & 0.1938 & -0.2683 & $\begin{array}{c}0.223 \\
9\end{array}$ & -0.1633 & -0.1044 & -0.0569 & -0.0386 & 0.0090 & .0021 \\
\hline & $\begin{array}{c}0.666 \\
7\end{array}$ & 0.3199 & 0.0704 & .1406 & 0.1550 & 0.1355 & 0.1006 & 0.0817 & 0.0387 & .0078 \\
\hline & 0.666 & 0.6554 & -0.4873 & 0.348 & -0.20985 & 0.09346 & 0.01146 & 0.0160 & 0.0511 & 6 \\
\hline
\end{tabular}
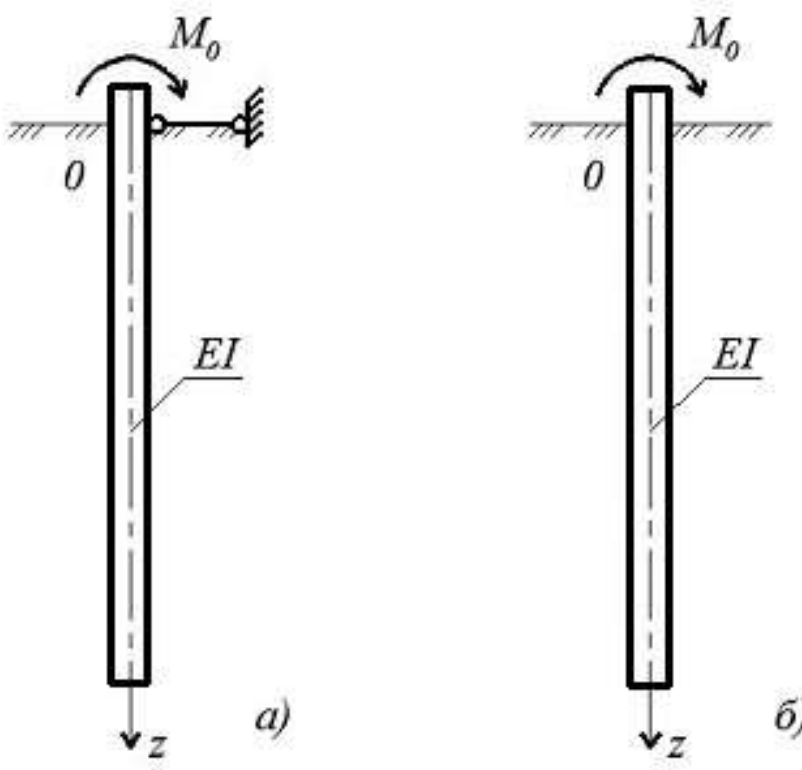

Малюнок 32. Розрахункова схема до прикладу розрахунку 7

Аналіз отриманих результатів свідчить про те, що наявність розпірки в рівні поверхні грунту, наприклад, при влаштуванні огороджень траншей i котлованів, призводить не тільки до істотного зниження горизонтальних переміщень і зменшення кутів повороту паль, а й істотно змінює значення згинальних моментів по глибині паль. 
Відзначимо, що при $\bar{l} \leq 4$ в межах $0 \leq \bar{z} \leq 4$ значення $U_{1}{ }^{z}, U_{2}{ }^{z}, U_{3}{ }^{z}$ i $U_{4}{ }^{z}$ не змінюються.
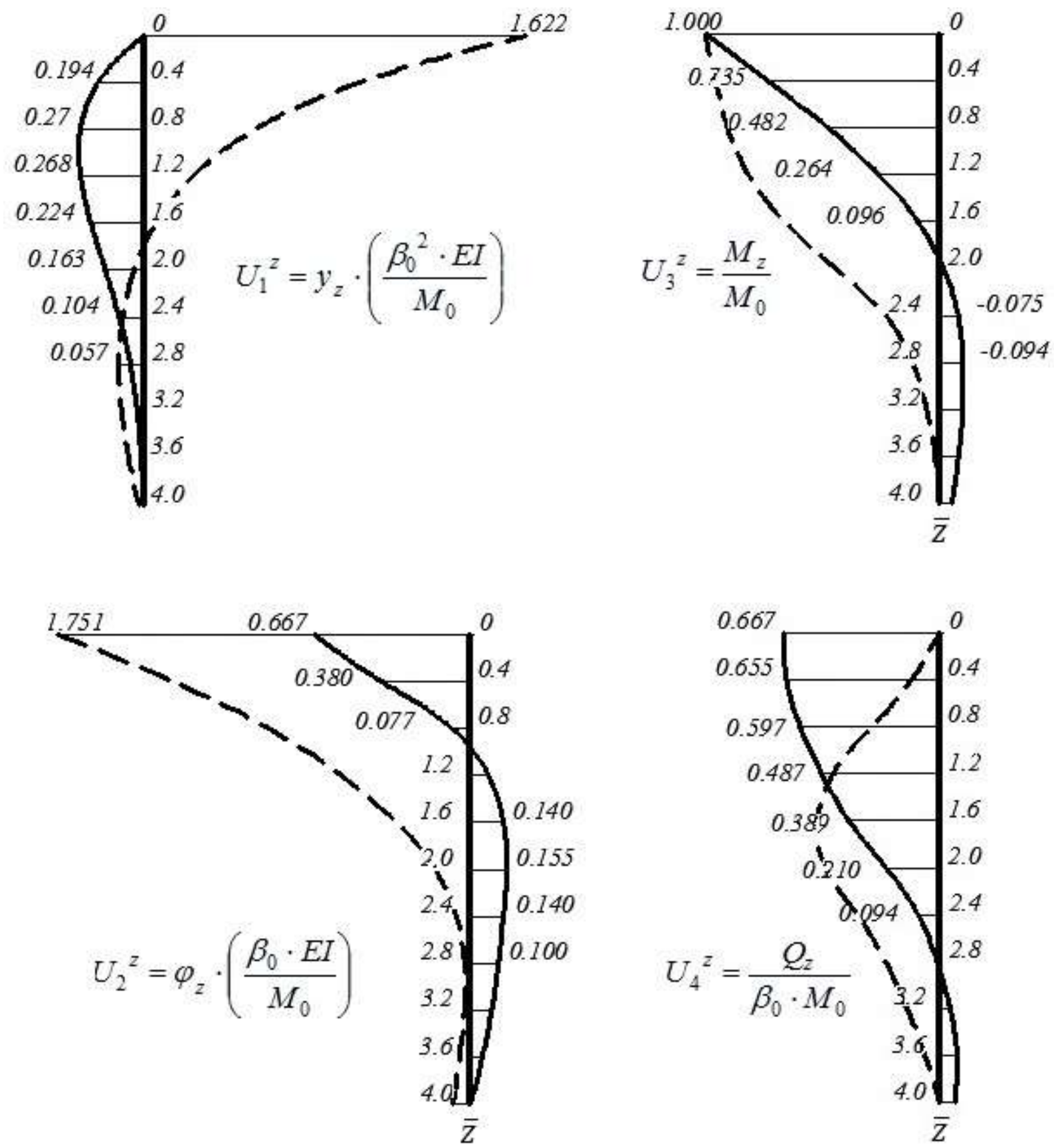

Малюнок 33. Графіки функцій $U_{1}{ }^{z}, U_{2}{ }^{2}, U_{3}{ }^{z}$ i $U_{4}{ }^{z}$ при $\bar{l}=4$ i $t=0$ (суцільною лінією - паля з розпіркою; пунктирною лінією - паля з вільною головою) 
Використовуючи рішення пружно-миттєвої завдання

$$
y_{0}{ }^{z}=\frac{M_{0}}{\beta_{0}^{2} \cdot E I} \cdot\left(C_{10}{ }^{z}-0.666 \cdot\left(B_{10}{ }^{z}+D_{10}{ }^{z}\right)\right),
$$

а також відому залежність деформування пружного Вінклерової основи

$$
y_{0}{ }^{z}=\frac{\sigma_{0}}{C_{0} \cdot b_{p}},
$$

представимо рівняння розподілу контактних напружень в пружною стадії у вигляді:

$$
\sigma_{0}^{z}=\beta_{0}^{2} \cdot \bar{z} \cdot M^{0} \cdot\left[C_{10}^{z}-0.666 \cdot\left(B_{10}^{z}-D_{10}^{z}\right)\right]
$$

де $\bar{z}=\beta_{0} \cdot z$ - показник наведеної глибини поперечного перерізу палі.

3 урахуванням (144) вихідне диференціальне рівняння задачі тривалого навантаження палі набирає вигляду:

$$
\begin{aligned}
& \frac{\partial^{4} y(\bar{z}, t)}{\partial \bar{z}^{-4}}+\overline{z_{t}} \cdot y_{t}^{\bar{z}}=\frac{\varphi_{t}}{2 \cdot K \cdot b_{p}} \beta_{0}^{2} \cdot \beta_{t} \cdot \bar{z} \cdot M_{0}\left[C_{10}{ }^{z}-0.666 \cdot\left(B_{10}{ }^{z}+D_{10}{ }^{z}\right)\right], \\
& \text { де } \beta_{t}=\sqrt[5]{\frac{2 \cdot K \cdot b_{p}}{\left(2+\varphi_{t}\right) \cdot E I}} .
\end{aligned}
$$

Приватне рішення можемо представити у вигляді:

$$
u=r_{1} \cdot B_{1}^{0}+r_{2} \cdot C_{1}^{0}+r_{3} \cdot D_{1}^{0} .
$$

Диференціюючи (146) отримуємо

$$
\frac{\partial^{4} u}{\partial z^{4}}=r_{1} \cdot\left(B_{1}^{0}\right)^{I V}+r_{2} \cdot\left(C_{1}^{0}\right)^{I V}+r_{3} \cdot\left(D_{1}^{0}\right)^{I V} .
$$

Використовуючи функції І.В. Урбана [54], можна показати, що існує співвідношення

$$
\frac{\partial^{4} u}{\partial z^{4}}=-\beta_{0} \cdot z \cdot\left(r_{1} \cdot B_{1}{ }^{0}+r_{2} \cdot C_{1}{ }^{0}+r_{3} \cdot D_{1}{ }^{0}\right),
$$

а 3 використанням приватного рішення (146), рівняння (145) має вигляд:

$$
\left(\beta_{t}-\beta_{0}\right)\left(r_{1} \cdot B_{1}^{0}+r_{2} \cdot C_{1}^{0}+r_{3} \cdot D_{1}^{0}\right)=\frac{\varphi_{t}}{2 K b_{p}} \beta_{0}^{3} \cdot \beta_{t} \cdot M_{0}\left[C_{1}^{0}-0.666\left(B_{1}^{0}+D_{1}^{0}\right)\right] .
$$


Прирівнюючи коефіцієнти при функціях початкового навантаження $B_{1}{ }^{0}$, $C_{1}^{0}$ і $D_{1}^{0}$, Знайдемо значення $r_{i}$, А потім і саме приватне рішення

$$
u=\frac{\varphi_{t}}{2 K \cdot b_{p}} \cdot \frac{\beta_{0}^{3} \cdot \beta_{t}}{\left(\beta_{t}-\beta_{0}\right)} \cdot M_{0}\left[C_{1}^{0}-0.666\left(B_{1}^{0}+D_{1}^{0}\right)\right] .
$$

Далі представимо спільне рішення однорідного рівняння (145)

$$
S=N_{1} \cdot C_{1}^{t}+N_{2} \cdot B_{1}^{t}+N_{3} \cdot D_{1}^{t} .
$$

3 урахуванням (150) i (151) запишемо рішення вихідного диференціального рівняння вигину палі

$$
\frac{\partial^{4} y_{t}^{\bar{z}}}{\partial z^{-4}}+\overline{z_{t}} \cdot y_{t}^{\bar{z}}=\frac{\varphi_{t} \cdot \beta_{t}}{2 \cdot K \cdot b_{p}} \cdot \sigma_{0}^{\bar{z}},
$$

у вигляді:

$$
\begin{aligned}
& y(\bar{z}, t)=N_{1} \cdot C_{1}{ }^{t}+N_{2} \cdot B_{1}{ }^{t}+N_{3} \cdot D_{1}{ }^{t}+ \\
& +\frac{\phi_{t} \cdot \beta_{0}^{3} \cdot \beta_{t}}{2 K \cdot b_{p}\left(\beta_{t}-\beta_{0}\right)} M^{0}\left[{C_{1}}^{0}-0.666\left(B_{1}{ }^{0}+D_{1}{ }^{0}\right)\right] .
\end{aligned}
$$

Довільніпостійні знаходимо з граничних умов:

$$
\begin{aligned}
& \text { при } z=0: y(0, t)=0 ; y^{\prime \prime}(0, t)=\frac{M^{0}}{E I} ; \\
& \text { при } z=H: y(H, t)=0 ; y^{\prime \prime}(H, t)=0 .
\end{aligned}
$$

Оскільки $\quad$ при $\quad \bar{z}=0: C_{1}(0)=B_{1}(0)=D_{1}(0)=0, \quad$ то $\quad$ умова $\quad y(0, t)=0$ задовольняється автоматично.

використовуючи залежність $y^{\prime \prime}(0, t)=\frac{M^{0}}{E I}$, визначимо

$$
\beta_{t}^{2} \cdot N_{1}+\frac{\varphi_{t} \cdot \beta_{0}{ }^{5} \cdot \beta_{t}}{2 \cdot K \cdot b_{p}\left(\beta_{t}-\beta_{0}\right)} \cdot M^{0}=\frac{M^{0}}{E I}
$$

звідки отримаємо

$$
N_{1}=\frac{M^{0}}{\beta_{t}^{2} \cdot E I}\left[1+\frac{\varphi_{t} \cdot \beta_{t}}{2 \cdot\left(\beta_{0}-\beta_{t}\right)}\right],
$$

а $з$ граничних умов на нижньому кінці палі, запишемо 


$$
\left.\begin{array}{l}
N_{2} B_{3 t}{ }^{H}+N_{3} D_{3 t}{ }^{H}=\frac{\varphi_{t}}{2 \beta_{t}\left(\beta_{0}-\beta_{t}\right) E I} M^{0}\left[C_{30}{ }^{H}-0.666\left(B_{30}^{H}+D_{30}^{H}\right)\right]-N_{1} C_{3 t}{ }^{H} ; \\
N_{2} B_{4 t}{ }^{H}+N_{3} D_{4 t}{ }^{H}=\frac{\varphi_{t}}{2 \beta_{t}\left(\beta_{0}-\beta_{t}\right) E I} M^{0}\left[C_{40}{ }^{H}-0.666\left(B_{40}{ }^{H}+D_{40}^{H}\right)\right]-N_{1} C_{4 t}{ }^{H} \cdot
\end{array}\right\} .
$$

Звернемо увагу на те, що при $z=l$ функції в дужках системи рівнянь (154), звертаються в нуль, а система спрощується

$$
\left.\begin{array}{l}
N_{2} \cdot B_{3 t}{ }^{H}+N_{3} \cdot D_{3 t}{ }^{H}=-N_{1} \cdot C_{3 t}{ }^{H} ; \\
N_{2} \cdot B_{4 t}{ }^{H}+N_{3} \cdot D_{4 t}{ }^{H}=-N_{1} \cdot C_{4 t}{ }^{H} \cdot
\end{array}\right\} .
$$

Це дозволяє, використовуючи (153), знайти довільні постійні $N_{2}$ i $N_{3}$

$$
\left.\begin{array}{l}
N_{2}=\frac{\left(C_{4 t}{ }^{H} \cdot D_{3 t}{ }^{H}-C_{3 t}{ }^{H} \cdot D_{4 t}{ }^{H}\right)}{B_{3 t}{ }^{H} \cdot D_{4 t}{ }^{H}-B_{4 t}{ }^{H} \cdot D_{3 t}{ }^{H}} \cdot \frac{M_{0}}{\beta_{t}{ }^{2} \cdot E I}\left[1+\frac{\varphi_{t}}{2 \cdot(\lambda-1)}\right] ; \\
N_{3}=\frac{\left(B_{4 t}{ }^{H} \cdot C_{3 t}{ }^{H}-B_{3 t}{ }^{H} \cdot C_{4 t}{ }^{H}\right)}{B_{3 t}{ }^{H} \cdot D_{4 t}{ }^{H}-B_{4 t}{ }^{H} \cdot D_{3 t}{ }^{H}} \cdot \frac{M_{0}}{\beta_{t}{ }^{2} \cdot E I}\left[1+\frac{\varphi_{t}}{2 \cdot(\lambda-1)}\right],
\end{array}\right\},
$$

де

$$
\lambda=\frac{\beta_{0}}{\beta_{t}}=\sqrt[5]{1+\frac{\varphi_{t}}{2}} .
$$

Відповідно до отриманого вище рішенням (135), залежності (136) спрощуються:

$$
\left.\begin{array}{l}
N_{2}=-\frac{M^{0}}{\beta_{t}^{2} \cdot E I} \cdot W_{t}^{H}\left[1+\frac{\varphi_{t}}{2 \cdot(\lambda-1)}\right] \\
N_{3}=-\frac{M^{0}}{\beta_{t}^{2} \cdot E I} \cdot R_{t}^{H}\left[1+\frac{\varphi_{t}}{2 \cdot(\lambda-1)}\right] \cdot
\end{array}\right\} .
$$

Рішення рівняння (152) отримає найбільш простий вид при $W_{t}=R_{t} \cong 0.666$ 


$$
\begin{aligned}
& y(z, t)=\frac{M^{0}}{\beta_{0}^{2} \cdot E I}\left\{\left[1+\frac{\varphi_{t}}{2(\lambda-1)}\right] \cdot U_{1 t}{ }^{z} \cdot \lambda^{2}-\frac{\varphi_{t}}{2(\lambda-1)} U_{10}{ }^{z}\right\} \\
& \varphi(z, t)=\frac{M^{0}}{\beta_{0} \cdot E I}\left\{\left[1+\frac{\varphi_{t}}{2(\lambda-1)}\right] \cdot U_{2 t}{ }^{z} \cdot \lambda-\frac{\varphi_{t}}{2(\lambda-1)} U_{20}{ }^{z}\right\} \\
& M(z, t)=M^{0}\left\{\left[1+\frac{\varphi_{t}}{2(\lambda-1)}\right] \cdot U_{3 t}{ }^{z}-\frac{\varphi_{t}}{2(\lambda-1)} U_{30}{ }^{z}\right\} ; \\
& \left.Q(z, t)=\beta_{0} \cdot M^{0}\left\{\left[1+\frac{\varphi_{t}}{2(\lambda-1)}\right] \cdot U_{4 t}{ }^{2} \cdot \frac{1}{\lambda}-\frac{\varphi_{t}}{2(\lambda-1)} U_{40}{ }^{2}\right\} \cdot\right\}
\end{aligned}
$$

Цікавим є зміна кута повороту палі $\varphi(0, t)$ в часі

$$
\varphi(0, t) \cong 0.666 \frac{M^{0}}{\beta_{0} E I}\left(\lambda+\frac{\varphi_{t}}{2}\right),
$$

що означає високу деформативність конструкції при контакті з глинистими грунтами, що володіють значною ползучестью.

\section{Приклад 8}

Розглянемо вплив повзучості основи на величини згинальних моментів, поперечних сил, горизонтальних переміщень і кутів повороту палі, завантаженої згинальним моментом $M_{0}=5 \mathrm{Tc} \cdot$ м у поверхні грунту, за таких умов: жорсткість $\begin{array}{llllll}\text { палі } & E I= & 6.2 & \cdot 10^{3} & \mathrm{Tc} \cdot \mathrm{M}^{2} ; & b\end{array}$ $H=6 \mathrm{M}, \quad \beta_{0}=0.66 \mathrm{~m}^{-1}, \beta_{0} \cdot H=3.95, b_{p}=1.1$ м. Грунт характеризується коефіцієнтом пропорційності: $K=700 \mathrm{Tc} / \mathrm{m}^{4}$.

Розглянемо рішення при декількох значеннях характеристики повзучості: $\varphi_{t}=0 \div 3$.

Графіки отриманих значень $y_{z}, \varphi_{z}, M_{z}$ i $Q_{z}$ в залежності від z для палі $з$ розпіркою представлені на Мал. 34. 

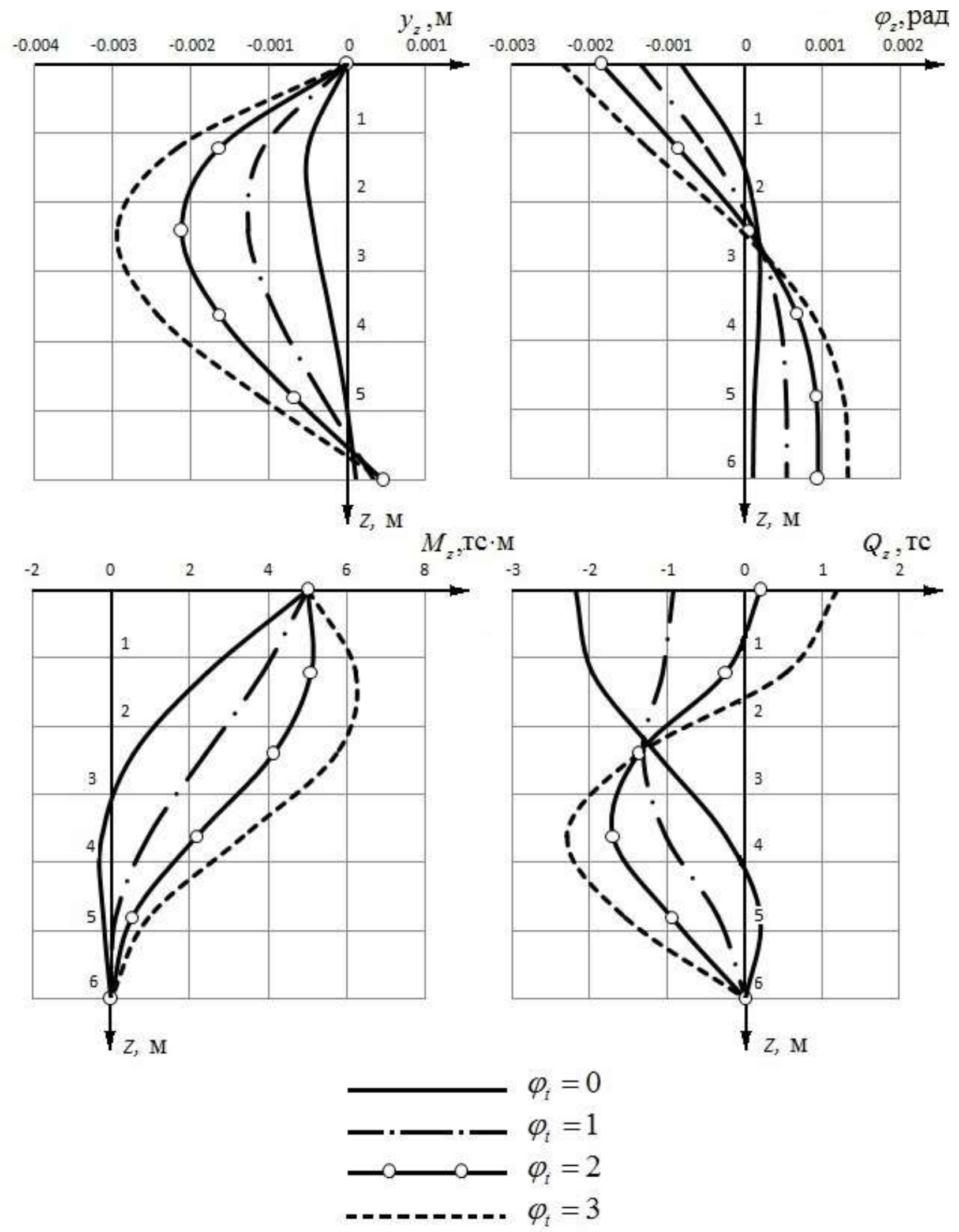

Малюнок 34. Епюри $y_{z}, \varphi_{z}, M_{z}$ i $Q_{z}$ для прикладу розрахунку 8 


\subsection{4 Лабораторні дослідження}

\subsubsection{1. Основні завдання експериментальних досліджень}

Використання існуючих методів розрахунку горизонтально навантажених паль часто призводять до суперечливих результатів. Встановити достовірність тієї чи іншої методики вдається лише, порівнюючи розрахункові дані 3 отриманими в ході дослідів результатами.

Застосування методів розрахунку, що моделюють грунт лінійнийдеформуємим середовищем, не дозволяє повністю використовувати несучу здатність горизонтально навантажених паль.

Основним завданням експериментальних досліджень було виявлення особливостей роботи паль на горизонтальну навантаження і встановлення характеру розподілу контактних напружень, а також деформацій стовбура паль різної жорсткості.

Методика експериментів будувалася з урахуванням вивчення напруженодеформованого стану системи «горизонтально навантажена паля-грунт». Для цього в процесі навантаження вимірювалися переміщення тіла палі на рівні поверхні грунту і на різних глибинах. Одночасно з переміщеннями визначалися контактні тиску.

Для випробувань були прийняті палі різного перетину і різної глибини занурення в грунт. Вибір таких розмірів паль забезпечував отримання як якісної, так і кількісної картини зміни напружено-деформованого стану досліджуваної системи. Прийняті глибини занурення дозволили віднести досвідчені палі як до категорії коротких (жорстких), так і гнучких, які часто використовуються в сучасній будівельній практиці.

4.1. Зразки експериментальних паль і контрольно-вимірювальні прилади

3 метою отримання експериментальних результатів щодо заявленої теми були виготовлені два металевих зварних лотка 500х520х100 (мм) і 750x730x100 (мм) 3 листової сталі товщиною1,5 мм і металевих куточків 30х30 і 35х35 мм 3 висувною передньою стінкою з литого полікарбонату товщиною 4 мм і акрилу товщиною 6 мм для паль завдовжки 555, 600 і 750 (мм). 
Для навантаження паль використані стандартні металеві гирі масою: 50; 100; 200; 500; 1000 (г) і спеціально виготовлені важки з листової сталі товщиною 8 і 16 (мм). Маса використаних в експериментах важків встановлена триразовим зважуванням на стандартних лабораторних вагах в лабораторії дослідження грунтів інституту «Харківводпроект».

Передача горизонтальних зусиль на голови паль від вертикально підвішеного набору важків здійснювалася за допомогою жорстких металевих $\Gamma$ образних шарнірних важелів з співвідношеннями коротких частин важелів до довгих 1: 7 i 1:10.

Фактичні горизонтальні зусилля на голови паль від вертикально підвішених вантажів встановлювалися за допомогою тензорезисторних динамометрів, вбудованих в гнучкі горизонтальні зчіпки між палями і важелями і передавалися на світлові табло процесорів (Мал. 35, 36) постійно протягом всього періоду кожного експерименту.

Палі.

Палі виготовлені з литого полікарбонату, що володіє в рівній мірі як і залізобетон досить високими характеристиками міцності і деформаційними властивостями. Кількість паль 4 шт. Розміри 555х30х24 (мм); 555x40х24 (мм); 600x30×20 (мм); 750x30×24 (мм).

Всі палі вирізані і оброблені на фрезерному верстаті 3 листового полікарбонату ТОВ «Полигаль Схід», виготовленого відповідно до ТУ 2246-00297726592-2008 «Монолітні панелі з полікарбонату».

Основні фізичні та механічні характеристики полікарбонату підтверджені сертифікатом якості:

густина - $1.3 \pm 0.15 \Gamma / \mathrm{cm}^{3}$;

міцність при розтягуванні (ГОСТ 11262-80) - 60-67 МПа;

модуль пружності при розтягуванні (ГОСТ 9550-80) - 2000 МПа;

відносне подовження при розриві не менше (ГОСТ 11262-80) - 30\%;

водопоглинання,\% по масі не більше (ГОСТ 4650-80) - 0.37. 
SCIENTIFIC FOUNDATIONS OF SOLVING ENGINEERING TASKS AND PROBLEMS

Грунт.

У всіх дослідах використовувався один i той же пісок Безлюдовського кар'єра Харківської області природної вологості $\left(\gamma=1.41 \Gamma / \mathrm{cm}^{3}\right.$, $\left.\varphi=33^{\circ}\right)$.

Досліди проводилися в приміщенні з відносною вологістю повітря 80-85\% і температурою $20-22^{\circ} \mathrm{C}$.

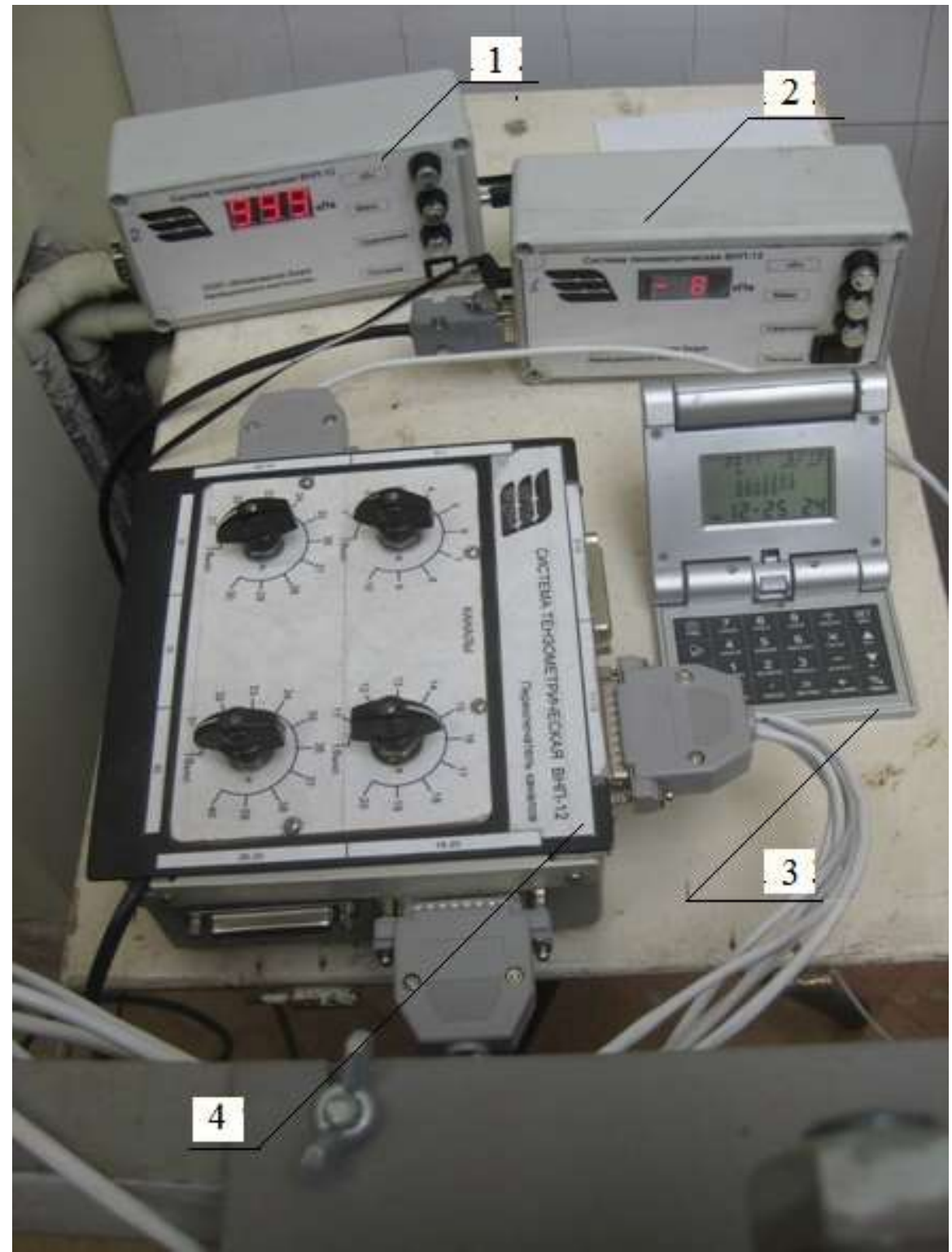

Малюнок 35. Контрольно-вимірювальна апаратура для вимірювань тиску 1 - процесор зі світловим дисплеєм №1; 2 - процесор зі світловим дисплеєм № 2; 3 - годинник; 4 - комутатор 


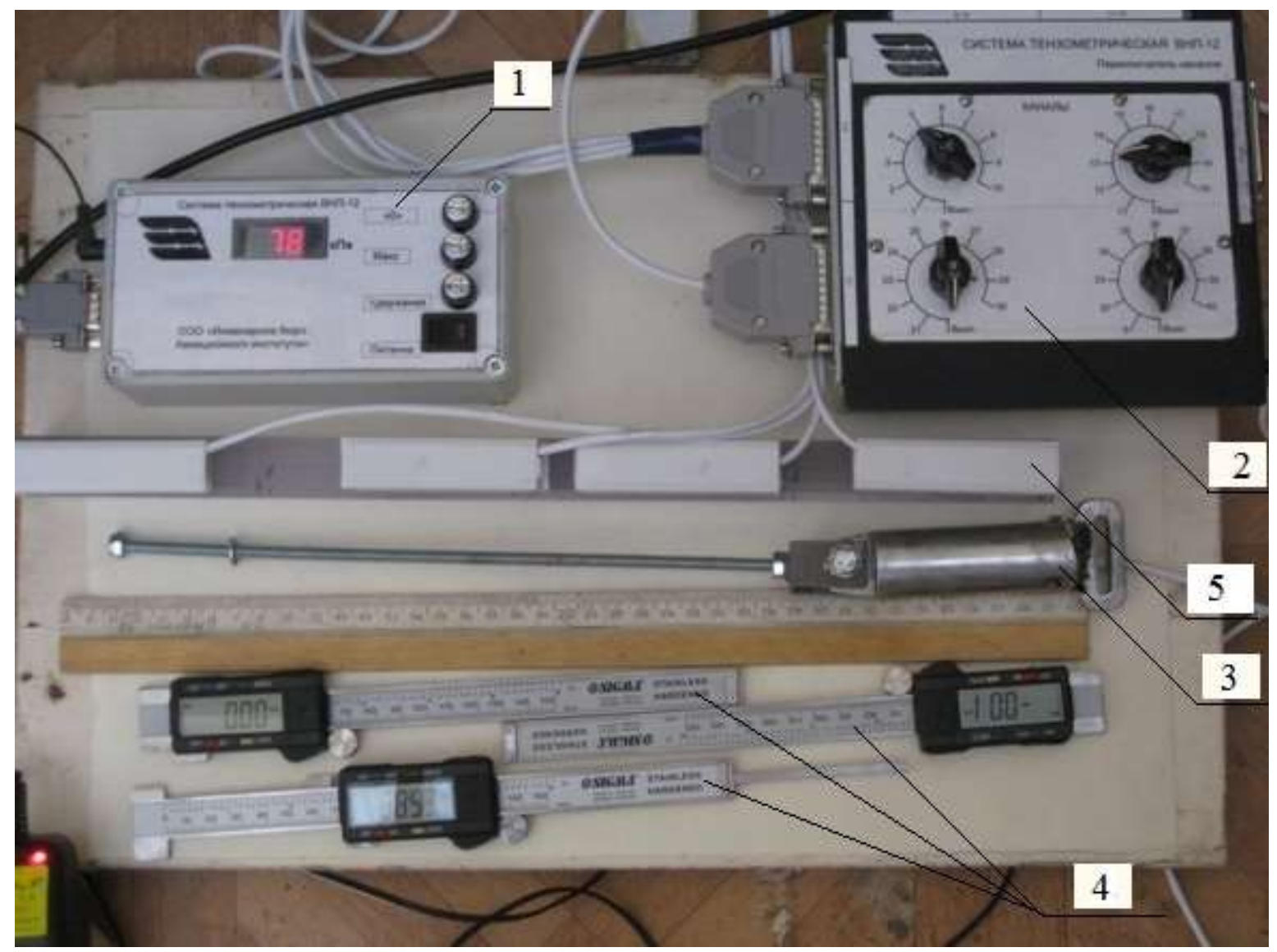

Малюнок 36. Контрольно-вимірювальна апаратура для вимірювання переміщень

1- процесор зі світловим дисплеєм; 2 - комутатор; 3 - динамометр; 4-електронний мікрометр з індикатором; 5 - паля $з$ датчиками 2 типу

Фізичні та механічні характеристики грунту визначені в сертифікованій лабораторії грунтів Українського державного інституту НІІНТІЗ за стандартними нормативним методикам.

Гранулометричний склад піщаного грунту визначено ситовим способом (табл. 4.1).

Відповідно до ДСТУ [57] відібраний пісок є піском середньої крупності. 
Таблиця 4.1

Гранулометричний склад грунту, використовуваного в експериментах

\begin{tabular}{|c|c|c|c|}
\hline \multicolumn{4}{|c|}{ Зміст окремих фракцій,\% } \\
\hline $1-0.5$ мм & $0.5-0.25$ мм & $0.25-0.1$ мм & $<0.1$ мм \\
\hline 1.8 & 23.7 & 65.2 & 9.2 \\
\hline
\end{tabular}

Завантаження лотків грунтом здійснювалася перед кожним дослідом після монтажу обладнання, установки паль i налаштування контрольновимірювальних приладів. Завантаження проводилася через лійку довжиною 0.8 м. Грунт розподілявся рівномірно по всій площі лотка шарами товщиною 3-5 см.

Контрольно-вимірювальні прилади (Мал. 37)

Для безперервних вимірювань фактичних горизонтальних зусиль впливають на голови паль в період проведення експериментів, між металевим захопленням голови палі і вантажним важелем системи завантаження встановлювався серійно випускається ТОВ «Інженерне бюро Авіаційного інституту» тензорезисторний динамометр 3 діапазоном вимірювань 1150 кг. Максимальна похибка вимірювань, гарантована виробником, при зчитуванні сигналу оригінальним процесором ВНП-12 - 0.5\% при зусиллі100 кг.

Для вимірювання горизонтальних переміщень в бічних панелях лотків уварені металеві втулки 3 діаметром отворів 2 мм. Через втулки до бічної поверхні палі встановлені металеві стрижні діаметром 1.5 мм. Довжина стержнів - 100-150 мм. В процесі експериментів вимірювалися величини горизонтальний переміщень стержнів (нижні датчики висувалися назовні, а верхні йшли в середину лотків). 


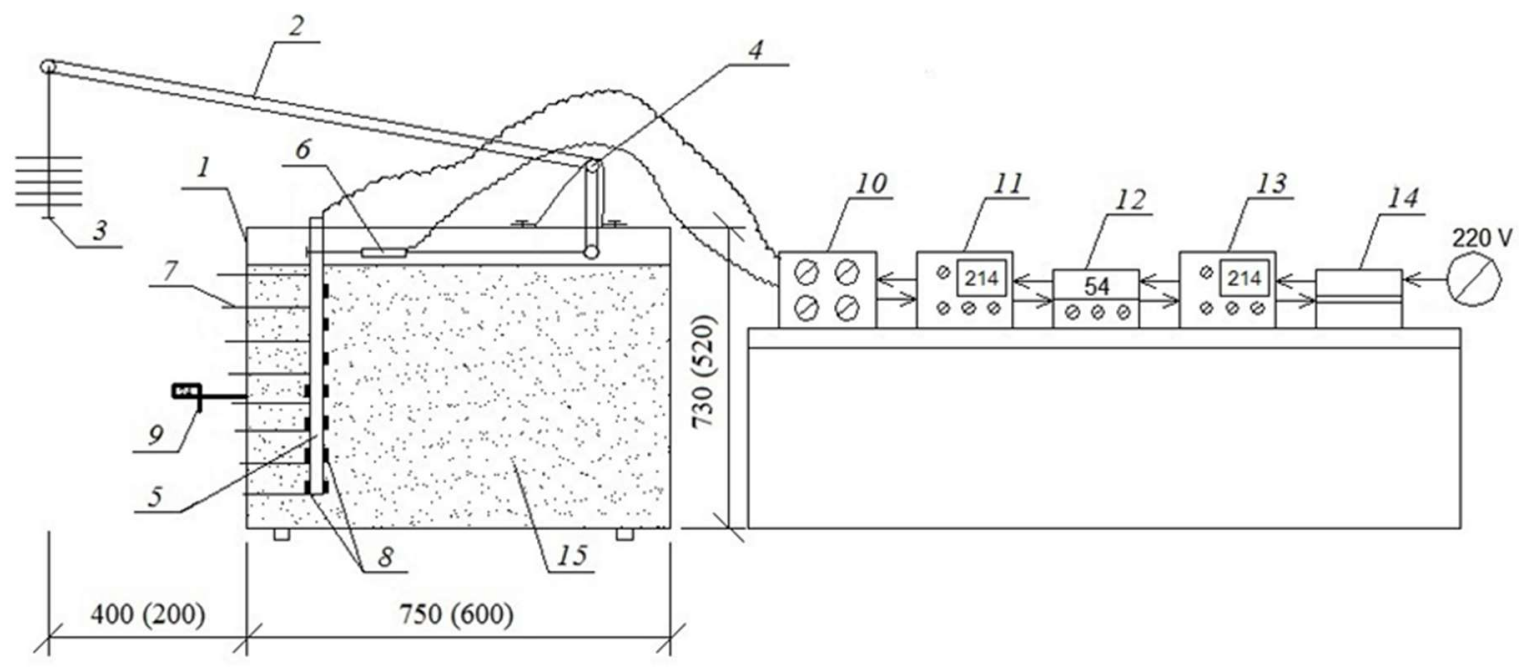

Малюнок 37. Схема механічного обладнання і контрольновимірювальних приладів:

1- металевий лоток з передньою стінкою з акрилу / полікарбонату;

2 - Г-подібний металевий шарнірний важіль; 3 - гнучка зчіпка з набором важків;

4 - шарнір; 5 - паля; 6 - динамометр в гнучкому зчепленні;

7- штоки для вимірювань переміщень; 8 - датчики тиску; 9 - електронний мікрометр з індикатором для вимірювання переміщень; 10 - комутатор;

11 - процесор зі світловим дисплеєм; 12 - електронний секундомір;

13 - дублюючий процесор; 14 - трансформатор 220 / 6V;

15 - дрібнозернистий пісок

Вимірювання горизонтальних переміщень стержнів (датчиків переміщень) визначалося трьома електронними індикаторами (мікрометрами) фірми «Sigma» (Китай) з автономними джерелами електроживлення. Результати вимірювань цих приладів виводилися на автономні рідкокристалічні дисплеї з інтервалом в одну соту міліметра. Гарантована виробником похибка цих приладів -0.02 мм, Тобто в діапазоні переміщень 330 мм похибка вимірювань не перевищувала 0.5\%. Перед кожним досвідом індикатори проходили перевірку за допомогою метрологічного набору стандартних пластин. Показники відповідали задекларованій виробником величині.

Вимірювання величин тисків, що виникали на контакті «паля-грунт», проводилися за допомогою тензорезисторних датчиків (Мал. 38), розроблених, виготовлених i змонтованих на палях фахівцями ТОВ «Інженерне бюро Авіаційного інституту» за участю д-ра техн. наук, проф. Лучковського І.Я. і аспірантки Єсакової С.В за підготовленим технічним завданням. 
Датчики тиску являють собою пластини з пружньої нержавіючої сталі, матеріал і розміри яких були визначені під можливий максимальний тиск грунту, допустимі деформації тензорезисторів, ненакоплення залишкових деформацій в пластинах після навантаження при величині їх прогинів не більше 5 мм. Один кінець цих пластин жорстко закріплений в виїмках паль, на іншому кінці жорстко прикріплені платформочкі, що виступають над навантаженими поверхнями паль на 1.5-2 мм в першому типі паль (Мал. 38, 39).

3 датчиками на задній площині паль (Мал. 38) у другому типі паль зусилля від грунту на металеві деформуються пластини датчиків тиску, закріплені на ненавантажуваних площинах паль передавалися через металеві платформочкі жорстко з'єднані з металевими штоками вільно пересуваються в тілі паль. Діаметр штоків -2.0 мм, отворів штоків - 8 мм.

Тип 1

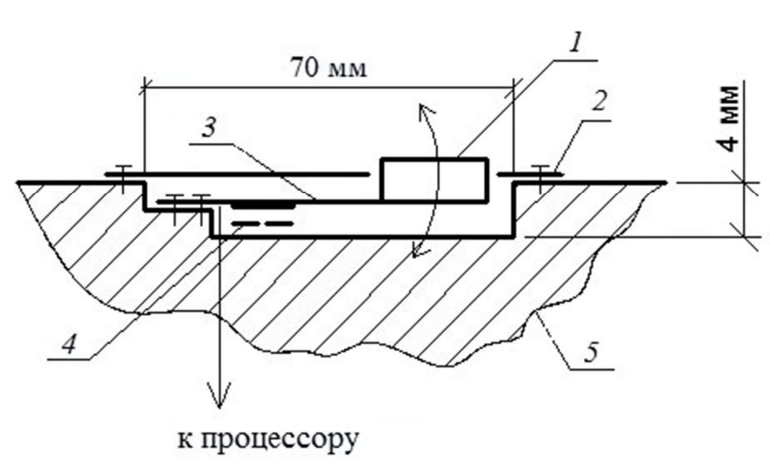

Тип 2

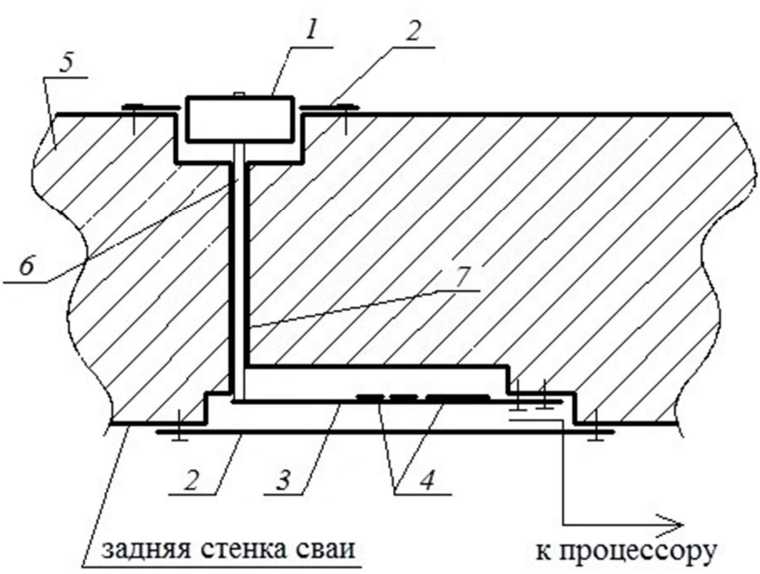

Малюнок 38. Схема датчиків тиску:

1 - платформа датчика тиску; 2 - кожух датчика; 3 - пластина 3 нержавіючої сталі 68×7x1.1 або 68×5x1 (мм); 4 - тензорезистор з набором опорів; 5 - тіло палі; 6 - шток; 7 - гіпоксідне мастилоПростір між штоками і тілами паль заповнений гіпоксідной мастилом. Переміщення штока 3 платформою щодо палі обмежена спереду палі платформочкой, з боку задньої поверхні палі -

гайкою, жорстко закріпленої на штоку. Максимальна глибина штока 3 платформою -5 мм, що відповідало максимальному розрахунковому тиску на платформи датчиків.

Всі експерименти були проведені з двома типами датчиків на палях, але більш стабільні результати були отримані в процесі експериментів 3 палями 3 
датчиками тиску першого типу, які були розташовані безпосередньо на навантажуються площинах.

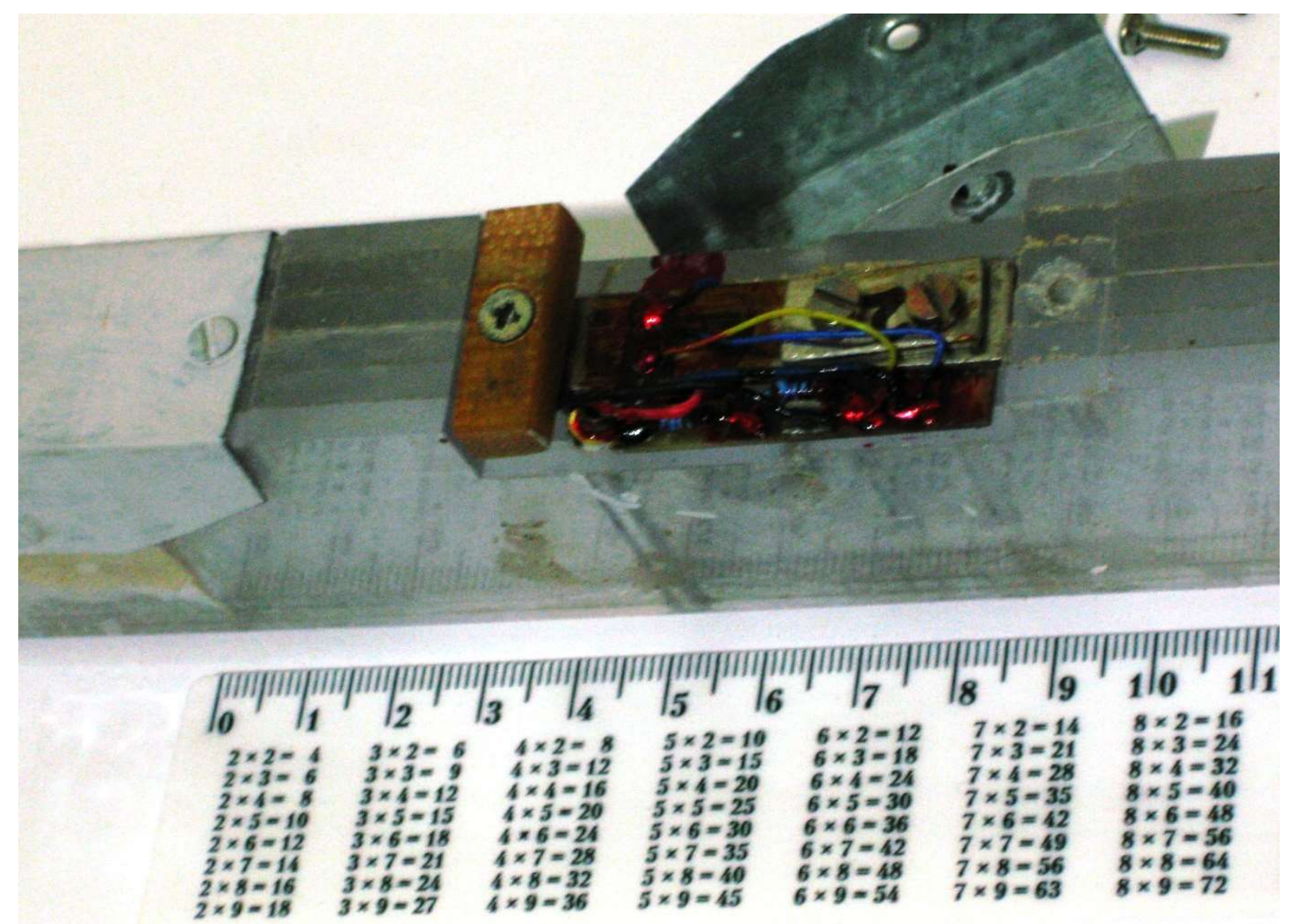

Малюнок 39. Датчик тиску без кожуха

3 нижнього боку металевих пластин датчиків тиску, що працюють як консоль, на прокладці з термостійкої паперу, просоченої фенольним клеєм УВС10T, тим же клеєм з подальшою термічною обробкою нанесені тензорезістори КФ5П1 R-200Ом сертифіковані Федеральним Агентством 3 технічного регулювання і метрології РФ (сертифікат UA .C.28.999 AN19997), поставлені ТОВ «ВЕДА» г. Киев а / с 54, мають граничне відхилення опору $\pm 1 \%$, Максимально вимірювану деформацію \pm 3000 мкм/м, Температурний режим роботи $-70^{\circ} 3 \ldots+200^{\circ} \mathrm{C}$. 
Як приймачів електричних сигналів від тензорезисторів і перетворення цих сигналів в світлові використані серійно випускаються ТОВ «Інженерне бюро Авіаційного інституту» мікропроцесори ВНП-12, що дозволяють перетворювати електричні сигнали тензорезисторов в цифрові на світловому табло безпосередньо в кПа на кожен датчик.

3 метою поєднання параметрів тензорезисторних датчиків і приймачів їх сигналів (мікропроцесорів) i зручності використання цієї пари приладів, до кожного датчика досвідченим шляхом підібрані свої резистори і вмонтовані під сталевими деформуємими пластинами кожного датчика.

Для зручності використання пари приладів датчик-приймач в електричний ланцюг між ними введено 48-канальний комутатор (перемикач каналів), що дозволяє отримувати інформацію з динамометра і будь-якого датчика тиску в будь-який час при приготуванні експериментів.

Всі прилади підключаються до безперебійного блоку живлення напругою 6V (Мал. 37).

1.3.4.1.3. Таріровка і випробування зразків експериментальних паль

3 метою уточнення характеристик міцності властивостей матеріалу паль були виготовлені 6 стандартних зразків в сертифікованої науково-дослідної лабораторії міцності і надійності авіаційних конструкцій національного аерокосмічного університету ім. Н.С. Жуковського і вироблені стандартні випробування відповідно до ГОСТ 11262-80 на розрив i стиснення на випробувальному стенді університету (випробувальна машина - ZD 10/90) (Мал. 40) за стандартною методикою. Присутній протокол випробувань, підписаний науковим керівником лабораторії, зав. кафедрою 102, проф. П. А. Фомічова. 


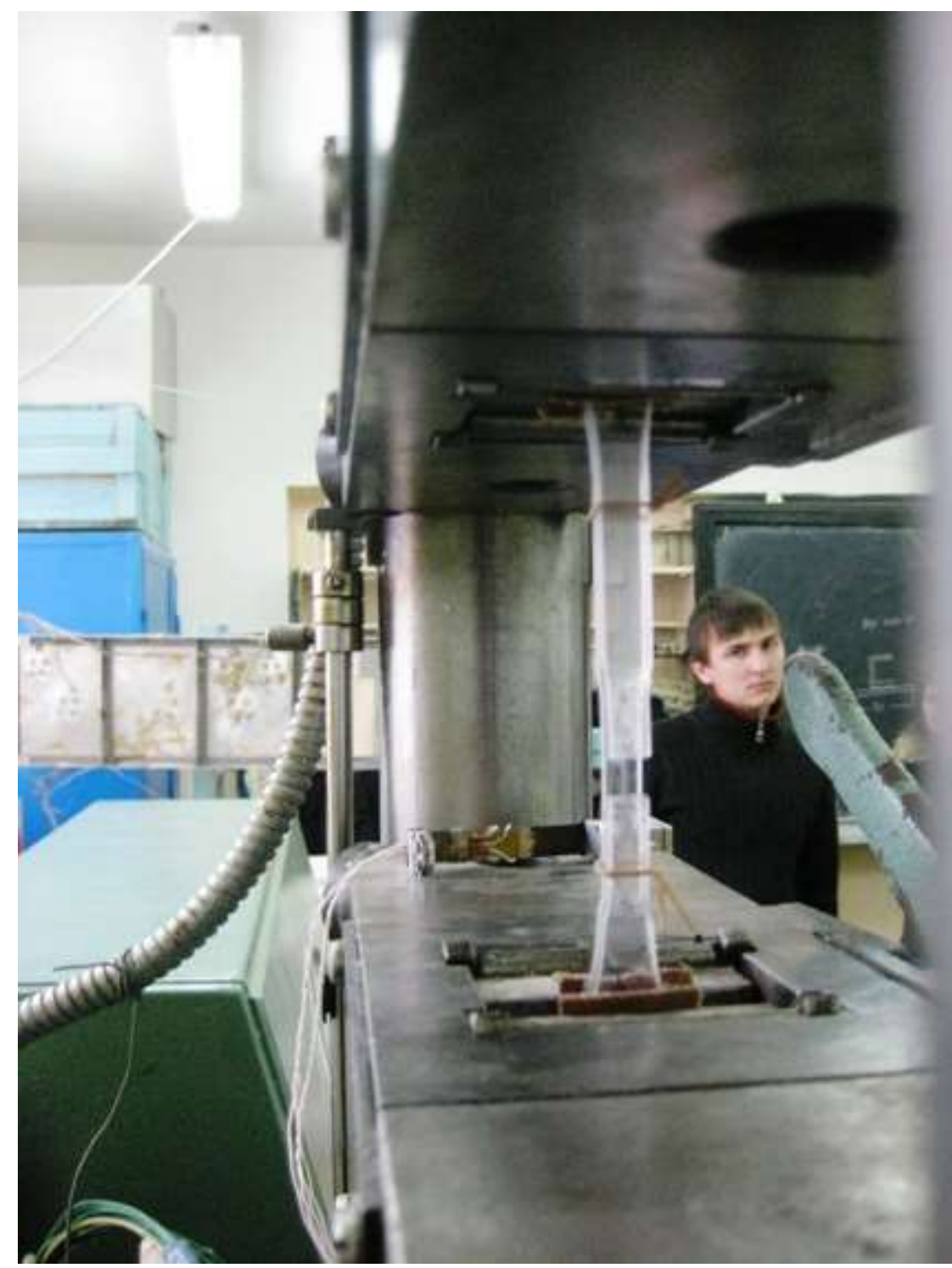

Малюнок 40. Процес випробувань полікарбонату на розтягнення

Результати випробувань представлені у вигляді таблиць і графіків залежностей $\Delta L=f(P)$ и $\sigma=f(\varepsilon)$ прикладених до протоколу випробувань.

\section{Випробуваннями встановлено:}

час до руйнування - $50 \ldots 55$ c;

розрахункова міцність при розтягуванні - 60.82 МПа, похибка - 0.604\%; розрахунковий модуль пружності - 1804.45 МПа, похибка - 1.092\%.

\subsubsection{4. Методика випробувань паль на горизонтальну навантаження}

3 метою якісного проведення експериментів була розроблена технологічна карта, яка передбачає порядок дій кожного учасника експерименту в період його проведення, підготовлені журнали тарувальних робіт і показників КВП. 

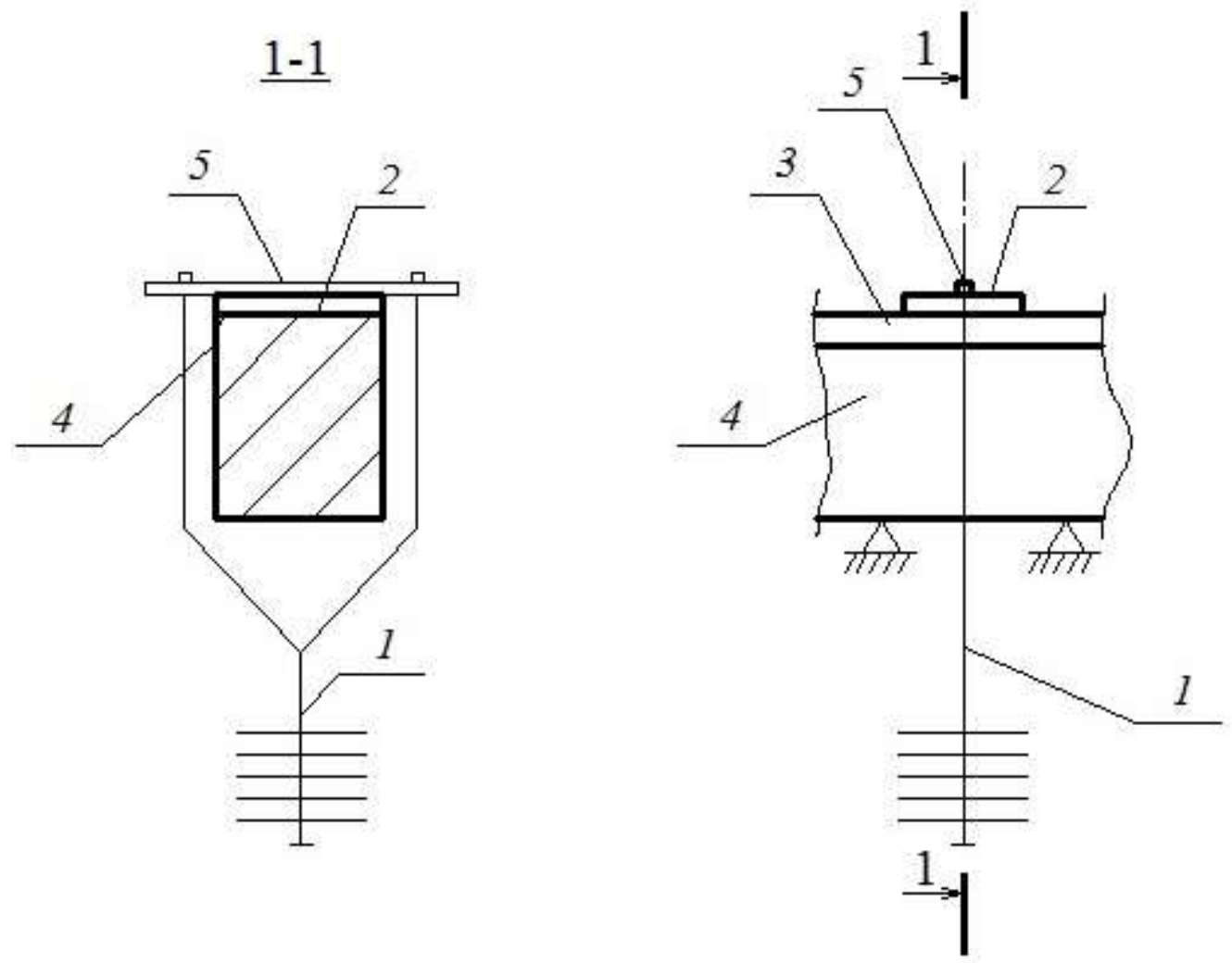

Малюнок 41. Спосіб тестування датчиків тиску:

1- гнучка зчіпка з набором важків; 2 - платформа датчика тиску; 3 - кожух датчика; 4 - тіло палі; 5 - металевий стрижень 3×3×70 мм

На Мал. 41 приведена схема тестування датчиків тиску. Проводилося тестування всіх датчиків перед кожним експериментом.

Заповнення лотка грунтом пошарово рівномірно шарами 23 см по всій площі короба за допомогою воронки (Мал. 42). 


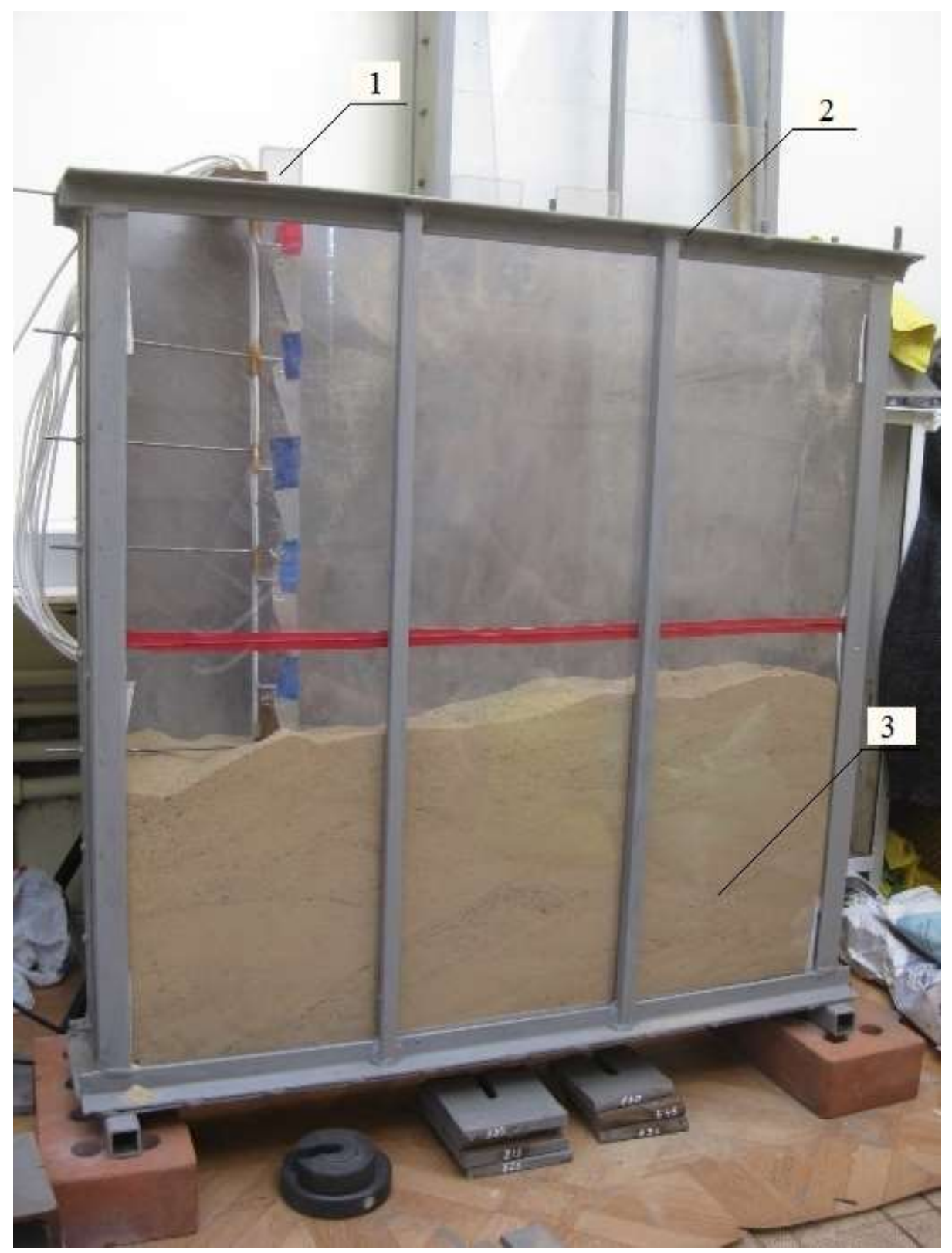

Малюнок 42. Вид на палю в процесі заповнення контейнера грунтом:

1 - паля; 2 - металевий лоток з передньою стінкою з акрилу / полікарбонату; 3 - піщаний грунт

Показники всіх датчиків фіксувалися в журналі спостережень 3 початку завантаження системи навантаження палі (Мал. 43) до закінчення експерименту (Мал. 44) і процесу розвантаження (Мал. 45). 


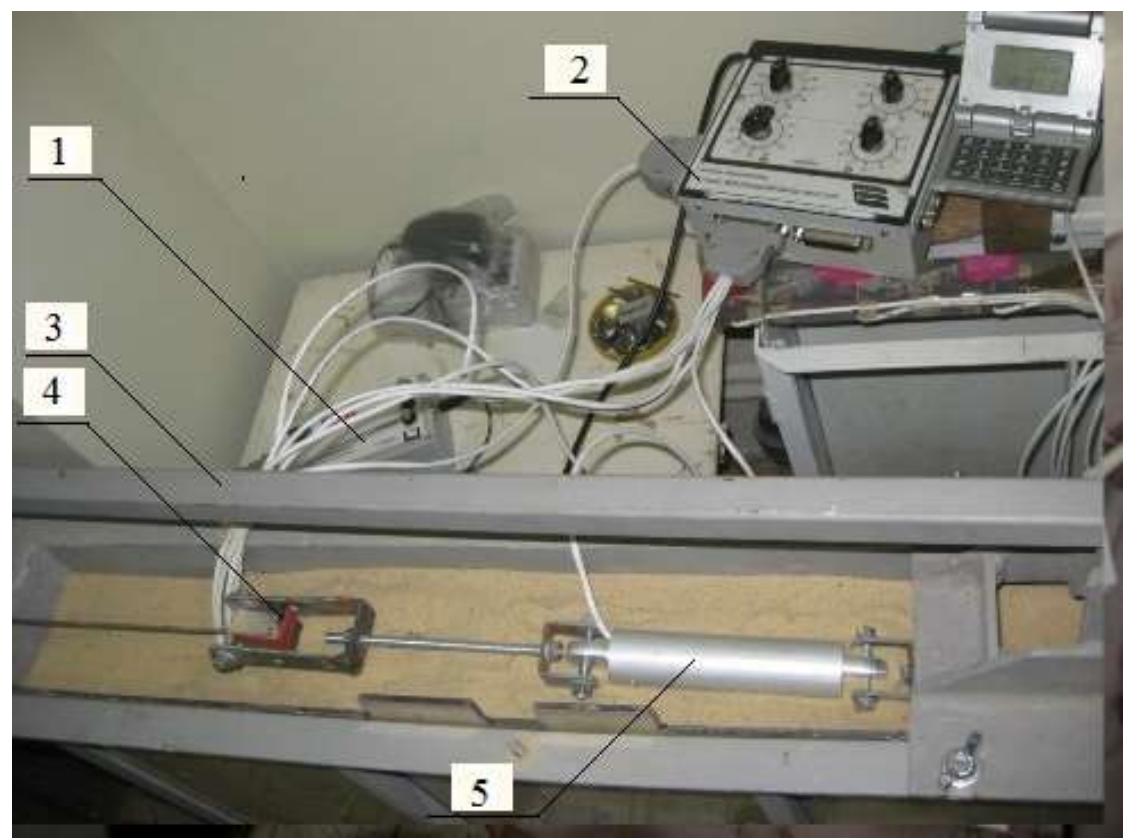

Малюнок 43. Хід експерименту. Вид на палю зверху:

1- процесор зі світловим дисплеєм №1; 2 - комутатор; 3 - металевий шарнірний важіль; 4 - динамометр на гнучкому зчепленні

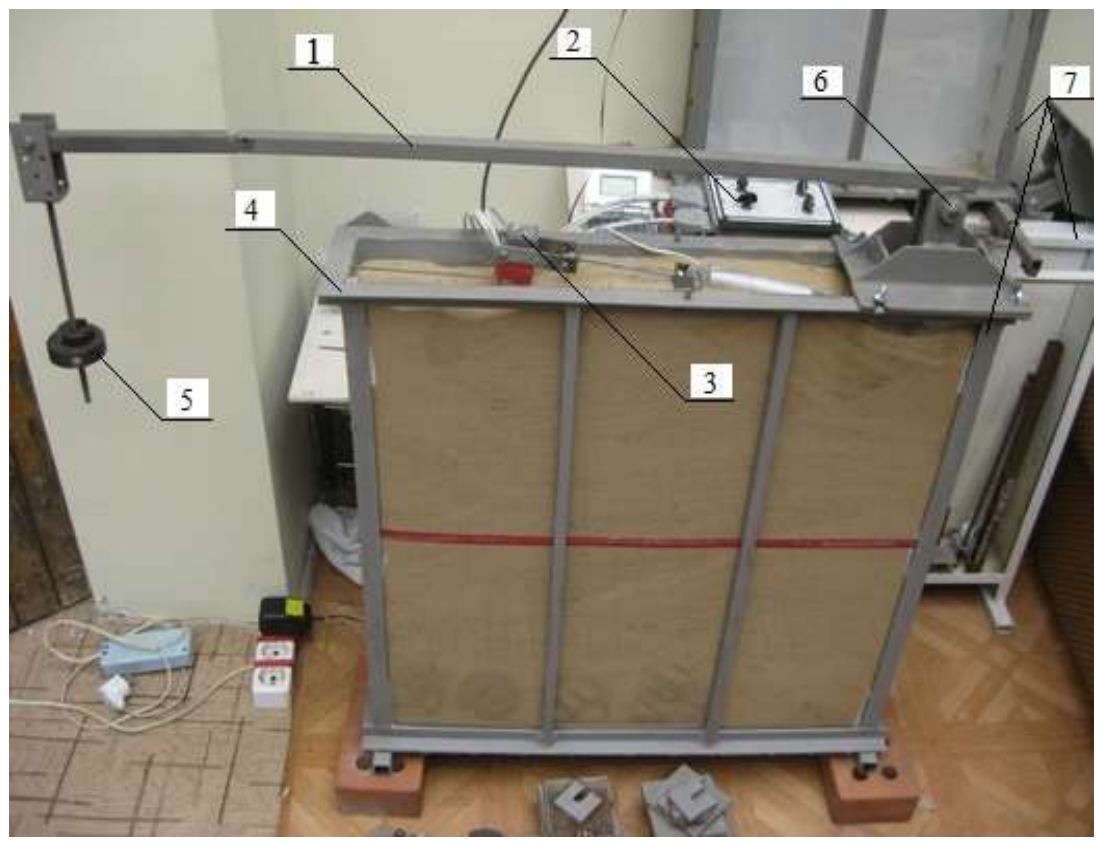

Малюнок 44. Вид на установку в процесі завантаження:

1 - металевий важіль; 2 - комутатор; 3 - паля;

4- металевий лоток з передньою стінкою з акрилу; 5 - вантаж; 6 - шарнір; 7 металеві лоток з передньою стінкою з акрилу / полікарбонату 


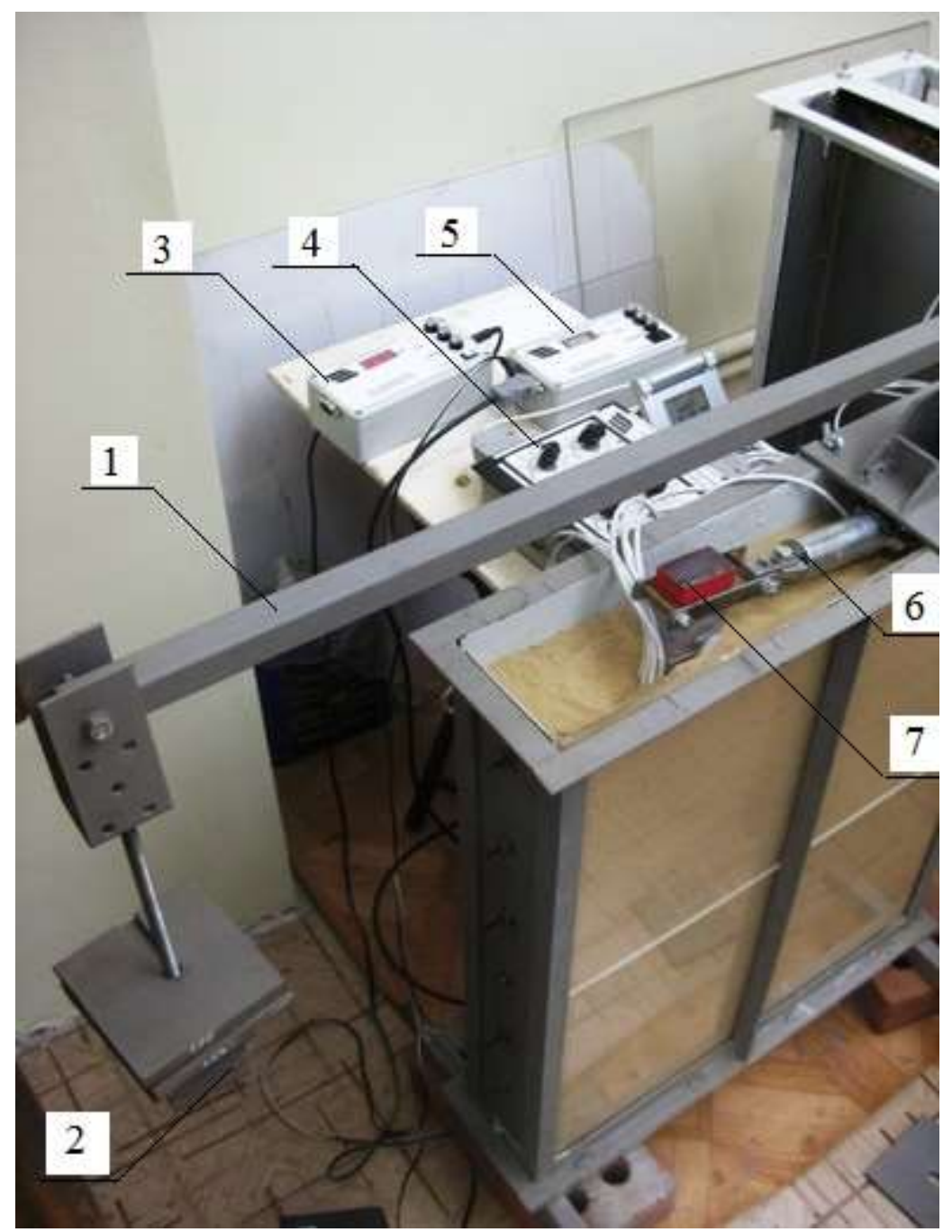

Малюнок 45. Вид на палю в процесі розвантаження:

1- важіль; 2 - вантаж, підвішений до гнучкому зчепленні; 3 - процесор № 1; 4- комутатор; 5 - процесор № 2; 6 - динамометр; 7 - паля

\subsubsection{5. Статистична обробка результатів експериментальних досліджень}

Як було зазначено вище, для кожного типорозміру палі (555x40x24, $555 \times 30 \times 20,600 \times 30 \times 20 \quad($ мм)) було проведено вимір горизонтального переміщення палі в залежності від горизонтального навантаження при іiі декількох значеннях. При кожному значенні навантаження дослід повторювали 5 разів. Цей масив даних був перевірений на виключення грубих помилок методом, при якому відома середньоквадратична похибка [58]. Результати перевірки показали, що грубих помилок допущено не було i все 
експериментальні дані придатні для статистичної обробки, яка була проведена за стандартною технологією, яку пояснимо на одному прикладі.

Для палі довжиною 555 мм 3 поперечним перерізом 30х20 мм при навантаженні 7 кгс було зафіксовано переміщення голови палі $y_{1}=11$ мм , $y_{2}=11.15$ мм,$y_{3}=10.85$ мм,$y_{4}=11$ мм,$y_{5}=10.95$ мм . Середнє значення переміщення склало $\bar{y}=10.99$ мм, а середнє квадратичне відхилення $\sigma=0.09 \varepsilon$ MM.

Так як отримане значення середнього та середньо-квадратичне відхилення $є$ оцінкою, то істинне значення знаходиться по залежності

$$
|a-\bar{y}|<t \cdot(\rho, k) \cdot \frac{\sigma}{\sqrt{n}},
$$

де $a$ - істинне значення;

$\bar{y}, \sigma$ - оцінка середнього та середньо-квадратичного значення, підраховані за експериментальними даними;

$t(\rho, k)$ - коефіцієнт Стьюдента [59], де

$\rho$ - достовірна ймовірність (надійність), яку приймемо на рівні 95\%;

$k=n-1$ - ступінь свободи;

$n$ - кількість експериментів $(n=5)$.

Для даного прикладу $t(\rho, k)=2.78$ і справжнє значення переміщення одно

$$
|a-\bar{y}|=2.78 \cdot \frac{0.098}{\sqrt{5}}=0.12 \mathrm{MM} .
$$

Для кожного експерименту довірчий інтервал завдано на Мал. 46, 47, 48.

Криві апроксимовані за допомогою сплайн-методу.

1.3.4.1.6. Порівняння теоретичних і експериментальних даних, чисельні дослідження

Достовірність прийнятої теоретичної моделі визначається ії здатністю описувати роботу реальної конструкції у всьому комплексі, на всіх стадіях роботи, відповідати як іiі деформованій схемі, так і напруженому стану. При 
цьому вона повинна відповідати різним граничним умовам, які трапляються в практиці. Крім того, стандартні випробування, на основі яких отримують розрахункові параметри грунтової основи, передбачають випробування поперечною силою, яка прикладається на рівні поверхні грунту. Таким чином, ці параметри як би відповідають одній граничній умові. Достовірність моделі визначається також тим, наскільки отримані дані відповідають іншим граничним умовам: горизонтальне навантаження прикладене на відстані $h_{1}$ від поверхні грунту або паля жорстко закріплена в ростверку.

Отже, відповідність повинна мати місце по напружено-деформованому стану, і для різних граничних умов.

\subsection{4. Результати експериментів}

На Мал. 46 показані графіки залежності $y_{0}=f(Q)$, епюри горизонтальних переміщень $y_{z}=f(Q)$, згинальних моментів $M_{z}=f(Q)$, відпору грунту $\sigma_{z}=f(Q)$ в функції від зовнішнього навантаження для горизонтально навантаженої палі розмірами 555x40х24 (мм). Ці палі відносяться до категорії жорстких (коротких) $\bar{l}=\alpha_{\text {д }} \cdot H=2.6$.

На Мал. 47 приведені ті ж залежності для палі розмірами 555х30х20 (мм). Палі є гнучкими $\bar{l}=\alpha_{\text {д }} \cdot H=3.1$.

Випробувані моделі палі з різними граничними умовами. На Мал. 48 представлена паля з опорою вище поверхні грунту на 100 мм, а навантаження прикладене на рівні поверхні грунту. Таким чином, можна випробувати палю при спільній дії згинального моменту i горизонтальної сили. Розміри паль 600х30×20 мм. 

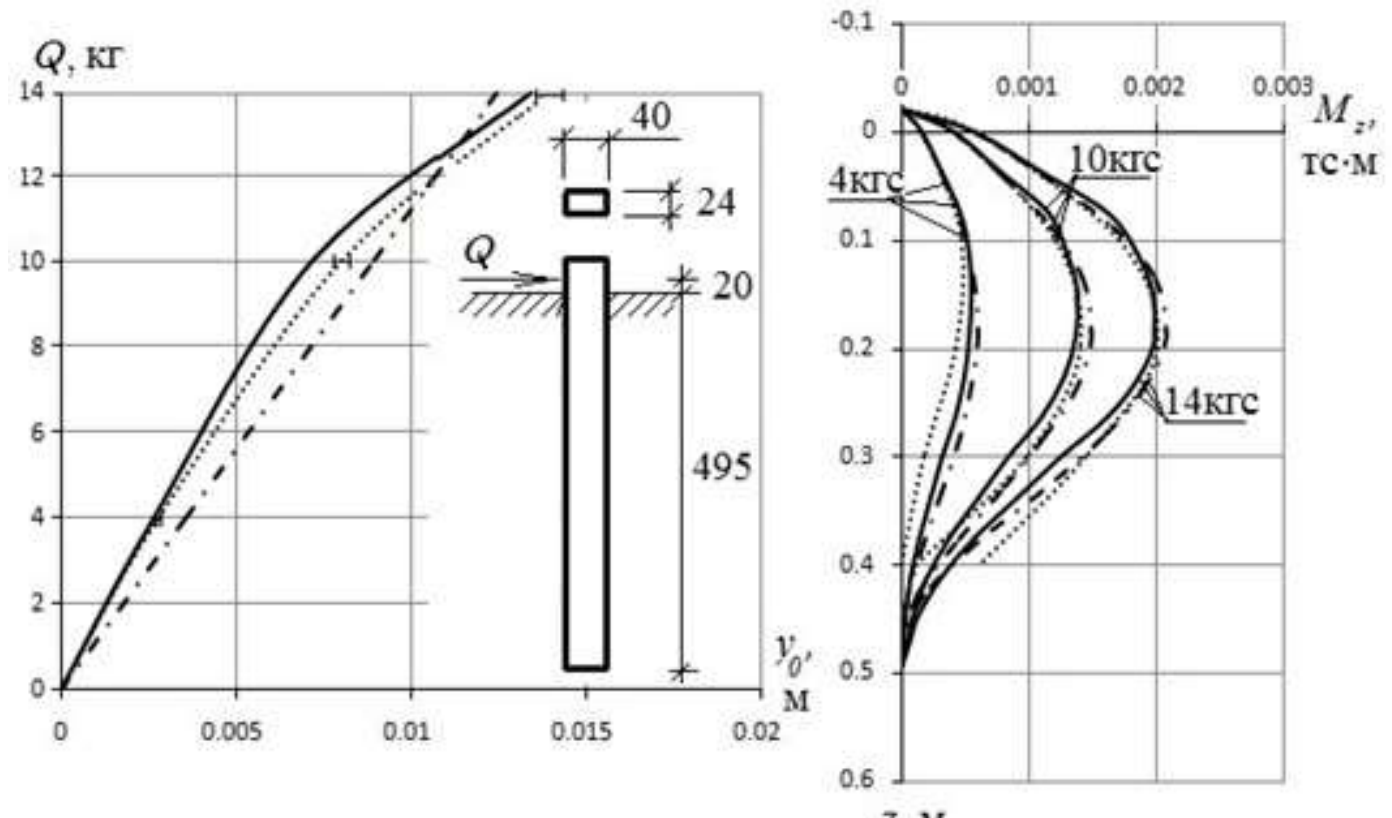

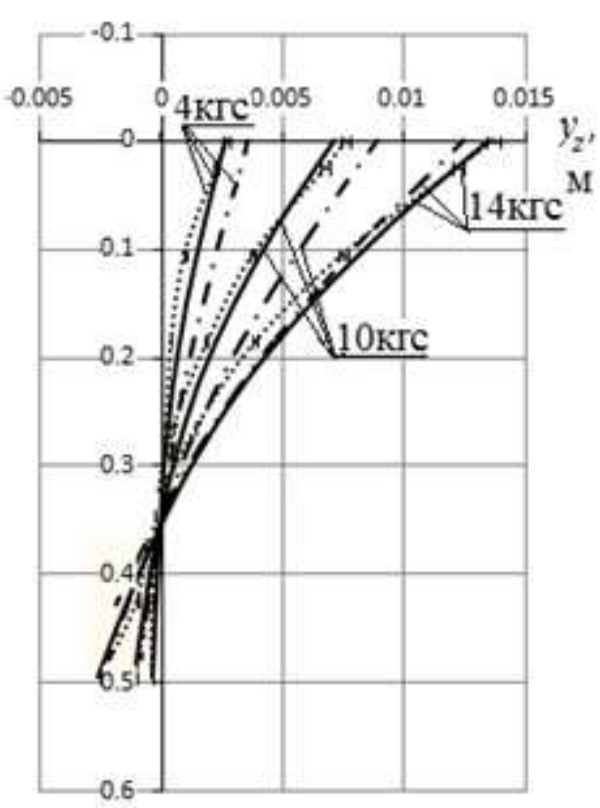

$Z, \mathrm{M}$

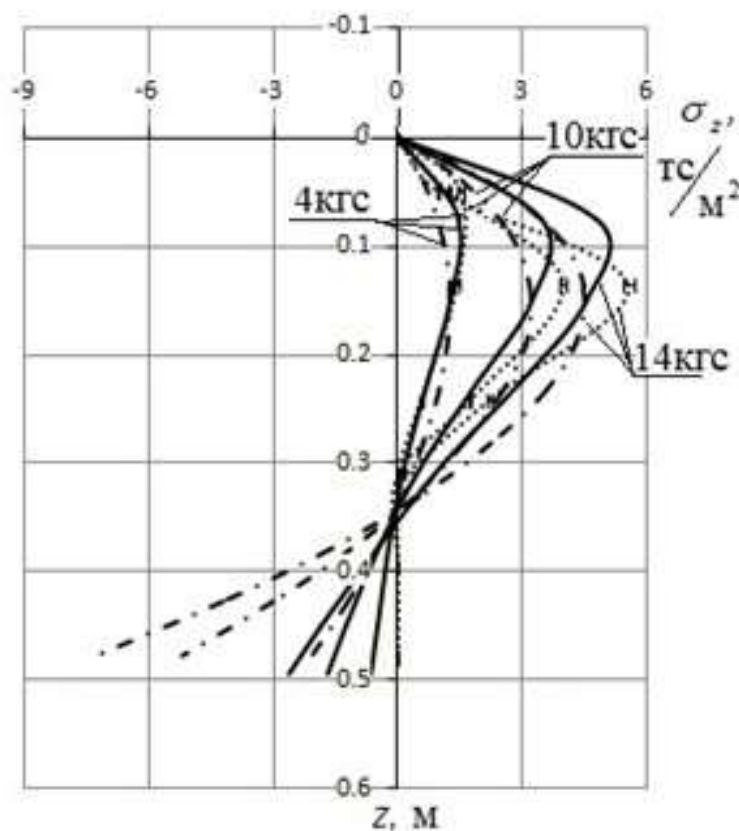

запропонована методика

методика "Керівництва" експериментальні дані інтервал довіри за експериментальними даними

Малюнок 46 Порівняння теоретичних та експериментальних даних (модельні палі). Графіки залежності $y_{0}=f(Q)$, епюри горизонтальних переміщень, згинальних моментів, опору грунту в функції від зовнішнього

$$
\text { навантаження }\left(y_{z}=f(Q), M_{z}=f(Q), \sigma_{z}=f(Q)\right)
$$



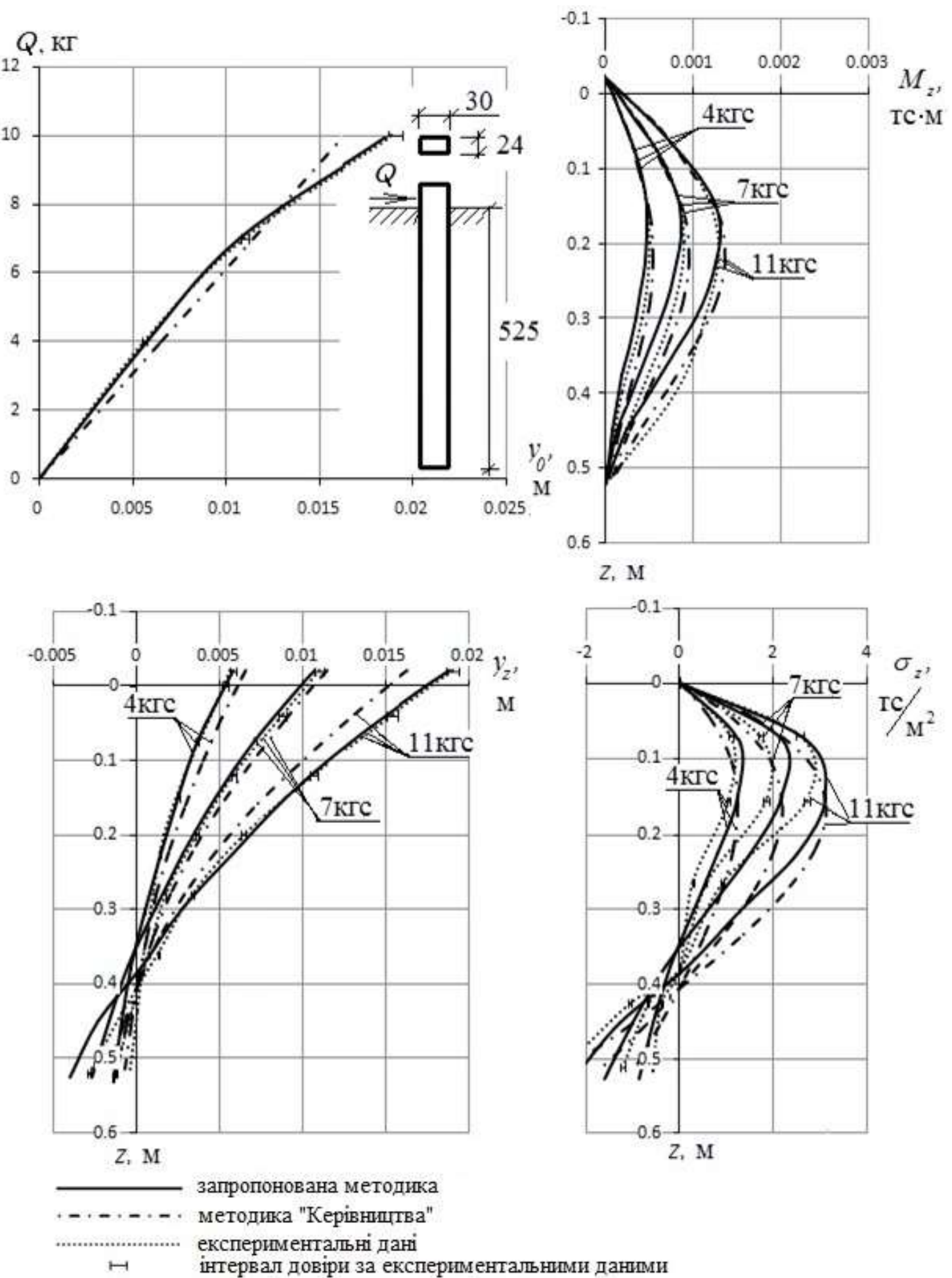

Z, M

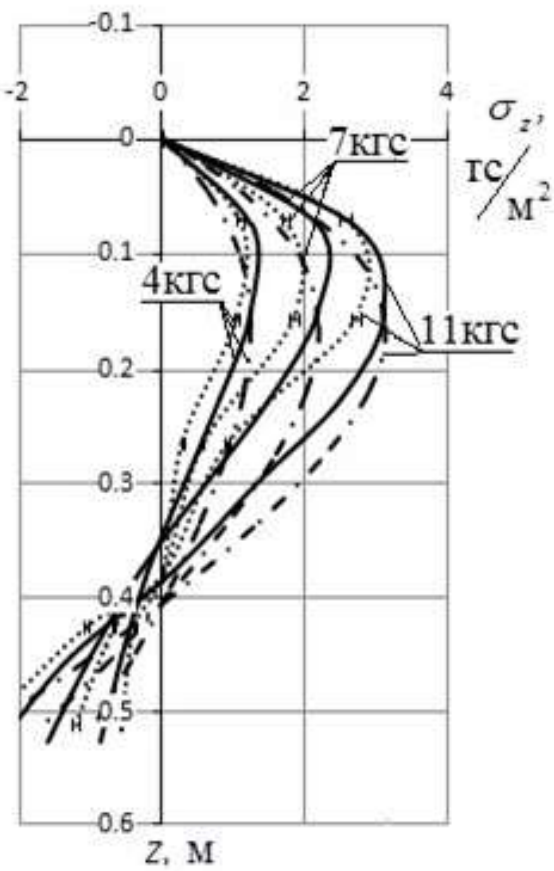

Малюнок 47. Порівняння теоретичних та експериментальних даних (модельні палі). Графіки залежності $y_{0}=f(Q)$, епюри горизонтальних переміщень, згинаючих моментів, опору грунту в функції від зовнішнього навантаження $\left(y_{z}=f(Q), M_{z}=f(Q), \sigma_{z}=f(Q)\right)$ 

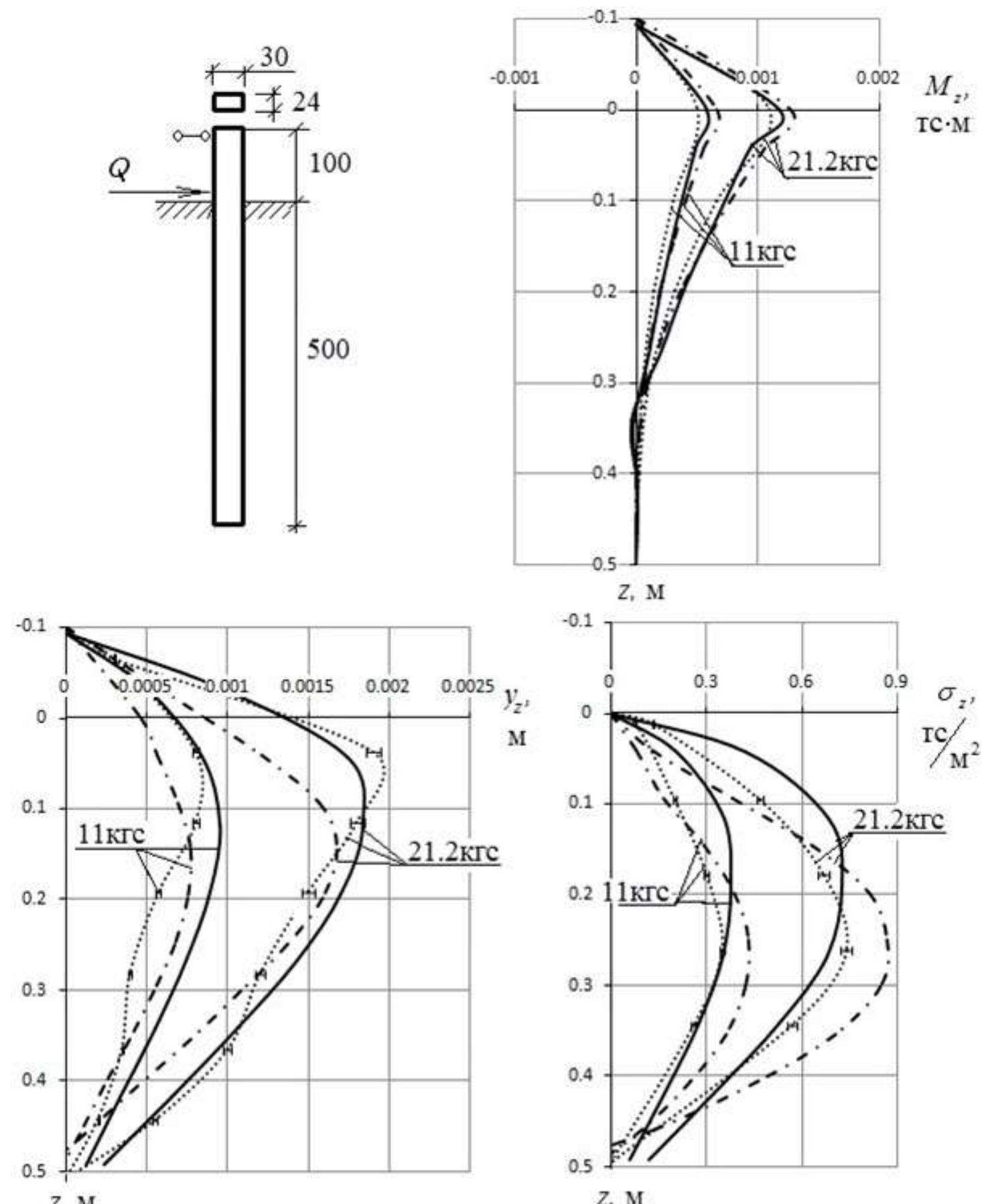

Z, M

$Z, M$

запропонована методика

методика "Керівницгва"

експериментальні дані

інтервал довіри за експериментальними даними

Малюнок 48. Порівняння теоретичних та експериментальних даних

(модельні палі). Епюри горизонтальних переміщень, згинальних моментів, опору грунту в функції від зовнішнього навантаження $\left(y_{z}=f(Q), M_{z}=f(Q)\right.$,

$$
\left.\sigma_{z}=f(Q)\right)
$$

У всіх випадках при розрахунках за запропонованою методикою використовувалася комплексна розрахункова модель № 2 (п. 1.1.2) 3 
експоненціальним розподілом коефіцієнта жорсткості основи по глибині. Як видно на Мал. 46, 47, 48, прийнята в наших розрахунках модель основи більш точно, в порівнянні з методикою «Керівництва» [48], описує напруженодеформований стан палі.

\subsubsection{3. Натурні випробування паль}

1.3.4.3.1. Експериментальний майданчик № 1 (Салтівський масив м.Харкова)

Експериментальний майданчик перебував на території Салтівського масиву м.Харкова. Розміри майданчика в плані 30х30 м.

Грунти основи складені покривними жовто-бурими суглинками $\left(I_{L}<0\right)$, Що переходять в червоно-бурі, карбонатними на глибині 4.5-5.0 м. Суглинки підстилає шар важкої супеси червоно-бурого кольору 3 прошарками дрібнозернистого піску, пластичної консистенції. Грунтові води на глибині 14 м не були знайдені.

Випробування натурних і великомасштабних моделей паль були проведені лабораторією фундаментів i підземних споруд Харківського ПромбудНДІпроекту А.Н. Довгим і Г.С. Лекумовічем під керівництвом Лучковського І.Я. [47]. Нижче наведено порівняння експериментальних результатів 3 теоретичними, отриманими за нашою методикою (п.1.1.2) 3 використанням експоненціального розподілу коефіцієнта постелі по глибині (Мал. 48, 49).

\subsection{1 Залізобетонні палі}

Дослідні залізобетонні палі перерізом 12x12 см, довжиною 3.0 м в кількості 25 штук були виготовлені на заводі ЗБК-1 трест «Харківзалізобетон».

В якості поздовжньої арматури в палях використовувалася сталь гарячекатана періодичного профілю Ø10 мм класу АIII. Поперечна арматура - 3 арматури Ø4 мм класу В-1.

Зусилля в арматурі по довжині палі визначалися за допомогою тензорезисторів 2-ПКБ-20-200 з базою20 мм і опором $R=199.4: 199.9$ ' Ом. 
Тензорезистори відбиралися таким чином, щоб розкид опору всередині кожної партії становив не більше 0.1-0.2\% від мінімальної величини опору. Вимірювання опору тензорезисторів проводилося омметром з ціною поділки 0.05 .

Тензорезистори наклеювалися в попередньо профрезерований в арматурних стержнях пазах шириною 4 мм і глибиною 3 мм. На кожен стрижень наклеювалося по 26 тензорезисторов, 52 тензорезистора на палю.

Тензорезистори наклеювалися на арматуру.

Фізичні характеристики бетону і арматури приймалися експериментальні і безпосередньо з випробувань паль. Тарирувальна залежність, що виражає зв'язок між величиною згинального моменту і показаннями тензостанціі наведена в [47]. експериментальна залежність $B_{x}=f(M)$ наведена в [45] і використовувалася нами в розрахунку пропонованим методом.

На Мал. 49 наведені графіки залежності $y_{0}=f(Q), y_{z}=f(Q)$ і $M_{z}=f(Q)$. Пропонована модель основи з використанням експоненційної епюри розподілу коефіцієнта жорсткості по глибині, дозволяє більш точно в порівнянні 3 нормативною методикою описати напружено-деформований стан горизонтально навантаженої палі. Порівняння теоретичних даних з експериментом показує, що в широкому діапазоні зростання навантажень спостерігається практично повний збіг з експериментом: різниця горизонтальних переміщень в рівні грунту становить менше 5\%, величини максимальних згинальних моментів за пропонованим методом відрізняються від експериментальних даних до 14\%, а за нормативним - до $23 \%$. 

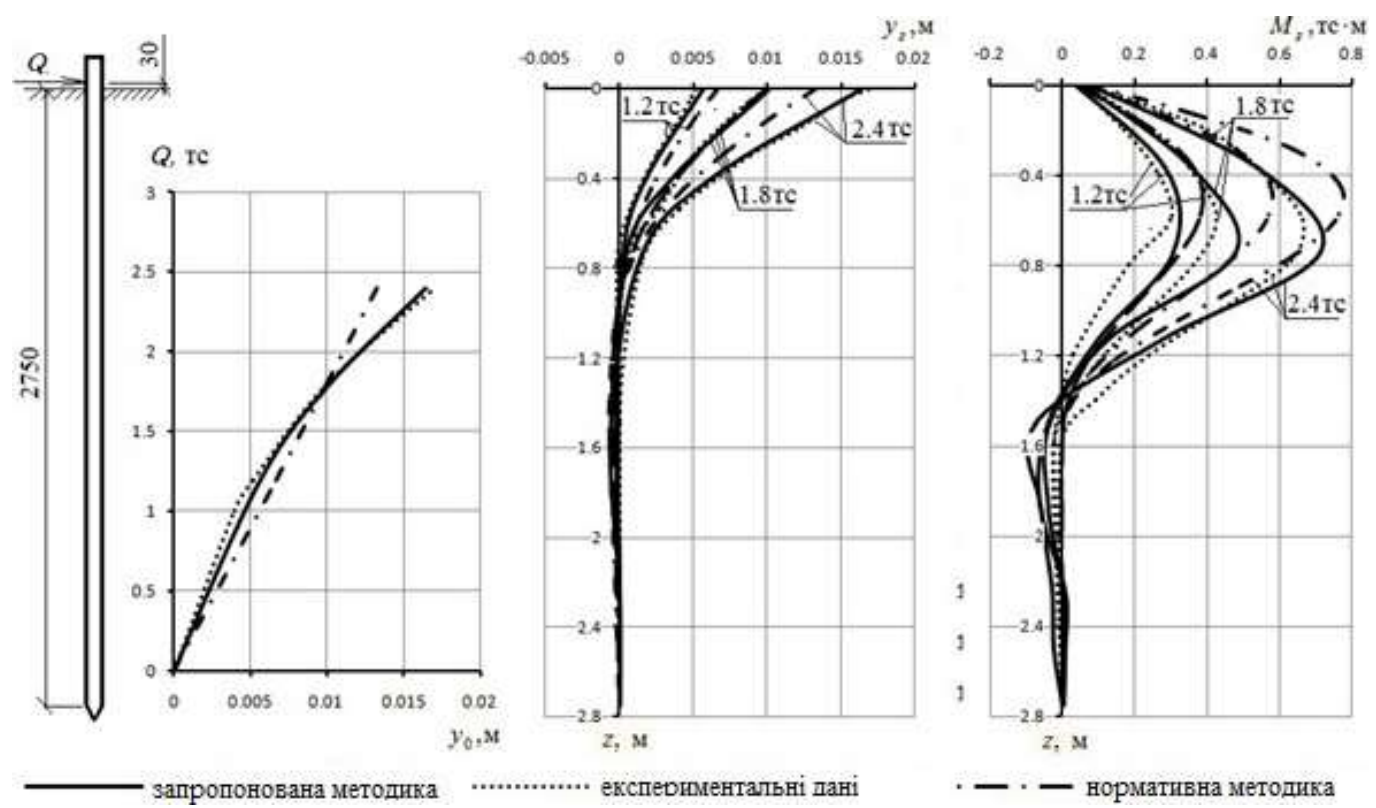

Малюнок 49. Порівняння теоретичних та експериментальних даних, майданчик № 1 (залізобетонні палі).

Графіки залежності $y_{0}=f(Q)$, епюри горизонтальних переміщень і згинальних моментів у функції від зовнішнього навантаження $\left(y_{z}=f(Q)\right.$, $\left.M_{z}=f(Q)\right)$

\subsection{2. Металеві палі.}

Металеві палі були виготовлені з двох швелерів № 12 довжиною 3 м, зварені в коробчатий перетин. При випробуванні паль на чистий вигин жорсткість палі склала. Модуль пружності металу $E_{a}=2.06 \cdot 10^{5} \mathrm{MH} / \mathrm{M}^{2}$.

Тензорезистори наклеювалися на внутрішню грань швелера по раніше описаній технології.

Як для залізобетонних, так і для металевих зразків паль проводилися вимірювання переміщень тіла палі в грунті через шурфи глибиною 1.2 м. Також для деяких залізобетонних та металевих паль, поряд зі зміною переміщення тіла палі в грунті, проводилися вимірювання деформації грунту перед палею. Деформації грунту, що оточує палю, вимірювалися за допомогою глибинних марок.

На Мал. 50 наведені епюри $y_{0}=f(Q), y_{z}=f(Q)$ і $M_{z}=f(Q)$. При розглянутих навантаженнях пропонована методика більш точно описує експериментальні криві. Так, при порівнянні горизонтальних переміщень на 
рівні грунту, розбіжність з експериментами становить не більше 15\%, розбіжність нормативної методики становить понад 40\%. Максимальні згинальні моменти, отримані за запропонованою моделлю основи 3 використанням експоненційної епюри розподілу коефіцієнта жорсткості по глибині, відрізняються від експериментальних даних на 10\%, а за нормативним методом - більше $40 \%$.

1.3.4.3.2. Експериментальні дослідження В.С. Миронова (м. Новосибірськ) Фізико-механічні властивості грунту дослідного майданчику Новосибірського інженерно-будівельного інституту, отримані на підставі проведених лабораторних досліджень, представлені в таблиці роботи [60]. Грунти до глибини 5 м складаються з маловлажних супісків середньої щільності.
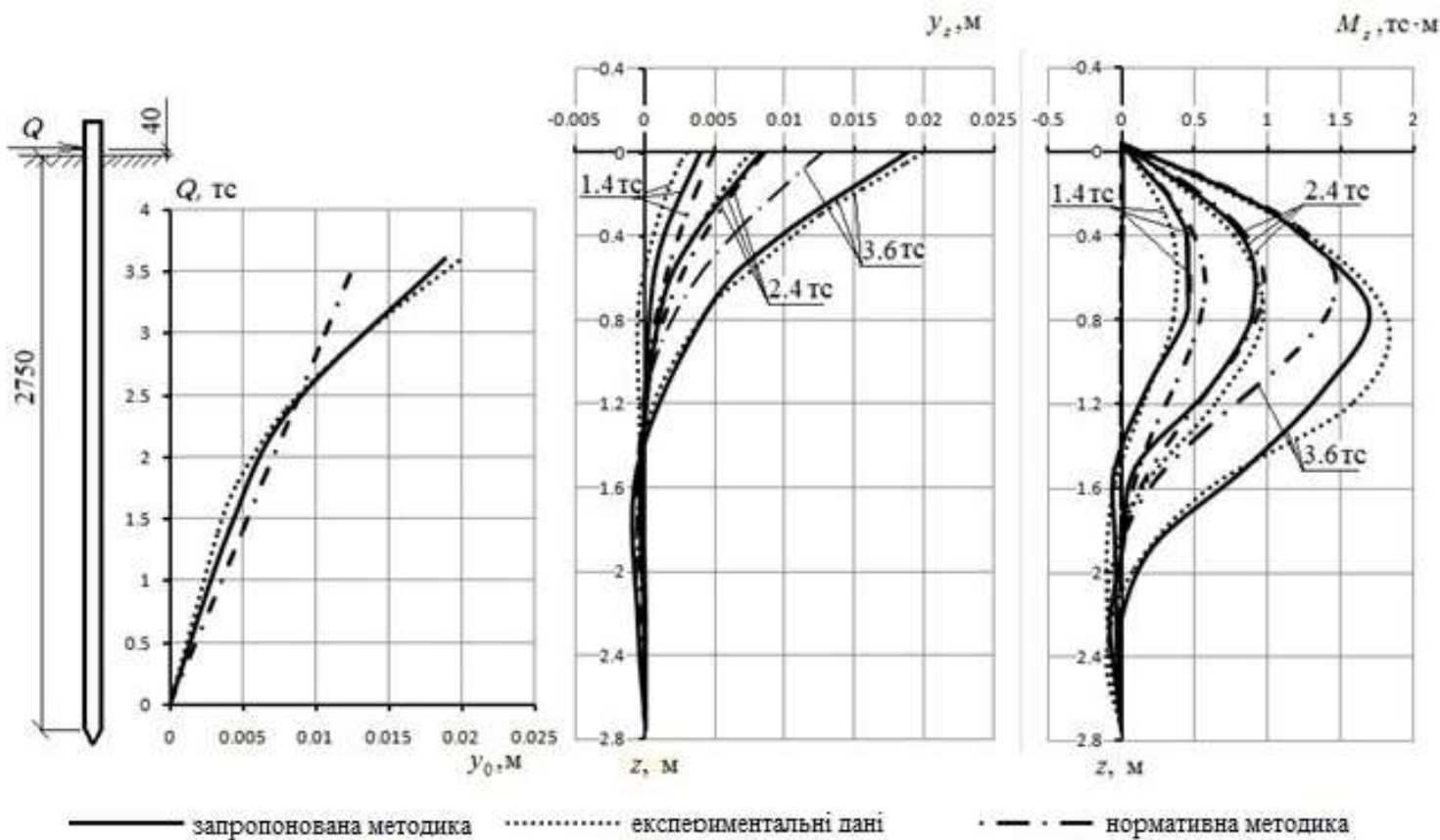

Малюнок 50. Порівняння теоретичних та експериментальних даних, майданчик № 1 (металеві палі).

Графіки залежності $y_{0}=f(Q)$, епюри горизонтальних переміщень і згинальних моментів у функції від зовнішнього навантаження $\left(y_{z}=f(Q)\right.$, $\left.M_{z}=f(Q)\right)$

Експериментальні палі довжиною 5 м виготовлялися зі сталевих суцільнотягнутих безшовних труб Ø 168 мм. На внутрішню поверхню стінок паль, уздовж їх поздовжньої осі були наклеєні дротові електротензодатчікі 3 однаковими характеристиками, надійно ізольовані від навколишнього середовища тонким шаром лаку і кабельною мастикою. Датчики наклеювалися 
за допомогою спеціальних струбцин через отвори Ø32 мм в стінці палі на відстані 80 мм від осі отвору.

Показання електротензодатчіков були протаріровани на палі Ø 168 мм при iii вигині від зосередженого навантаження на гідравлічному пресі. Електротензодатчікі з'єднувалися з вимірювальним приладом, що представляє собою змінену схему приладу ИД-59.

В результаті дослідів значення переміщень голови палі були отримані за прогиномірами, а за показаннями тензодатчиков - значення моментів, що діють в різних перетинах по довжині палі.

На Мал. 51 наведені графіки залежності $y_{0}=f(Q), y_{z}=f(Q)$ і $M_{z}=f(Q)$. Пропонована модель підстави з використанням експоненційної епюри розподілу коефіцієнта жорсткості за глибиною (п. 1.1.2) краще в порівнянні з нормативною методикою дозволяє описати експеримент: різниця горизонтальних переміщень в рівні грунту становить менше 5\%, величини максимальних згинальних моментів за пропонованим методом відрізняються від експериментальних даних до $20 \%$.
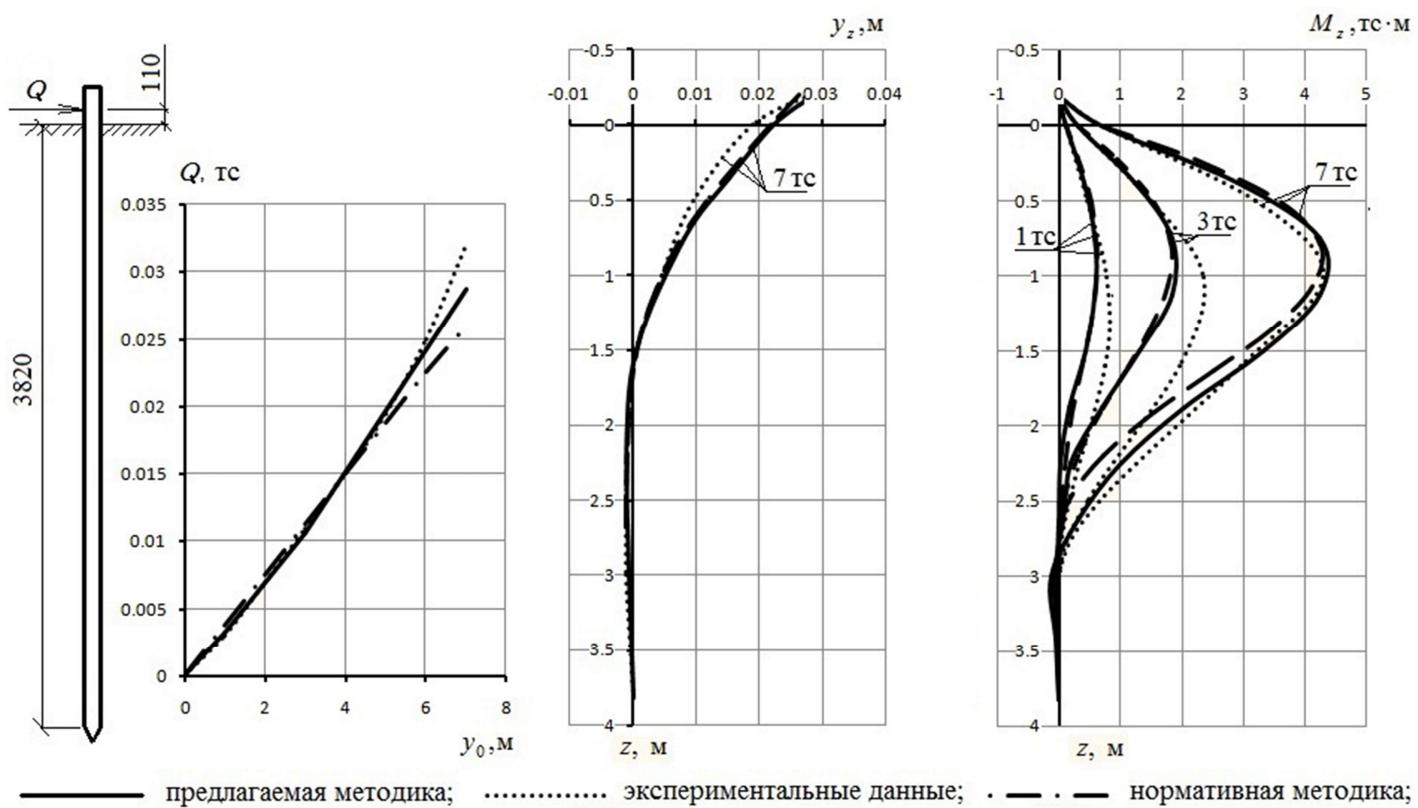

Малюнок 51. Порівняння теоретичних та експериментальних даних, майданчик № 3 (металеві палі).

Графіки залежності $y_{0}=f(Q)$, епюри горизонтальних переміщень і згинальних моментів у функції від зовнішнього навантаження $\left(y_{0}=f(Q)\right.$,

$$
\left.M_{z}=f(Q)\right)
$$


1.3.4.3.3. Експериментальний майданчик № 2 (м.Первомайськ, Харківська обл.)

Грунти в межах глибин занурення паль за фізико-механічними властивостями складаються 3 3-х шарів: лесовидні жовто-бурі суглинки переходять в суглинки лесовидні палево-жовті $\left(I_{L}<0\right)$. 3 глибини 5 м залягає важкий жовтувато-бурий суглинок $\left(I_{L}<0\right)$, щільність якого з глибиною зростає. Грунтові води бурінням до глибини 15.0 м не були знайдені.

На експериментальному майданчику № 2 були проведені випробування горизонтально навантажених металевих паль перетином 30х30 см, занурених в грунт на глибину 6 м.

a) На Мал. 52 наведені залежності $y_{0}=f(Q)$ і $M_{z}=f(Q)$ для металевих паль в щільному грунті природної вологості.

Епюри вигинає моментів $M_{z}=f(Q)$ металевих паль представлені на Мал. 52. Криві побудовані за експериментальними даними $\mathrm{i}$ за результатами розрахунку 3 використанням комплексної розрахункової моделі №3 3 синусоїдальною епюрою розподілу коефіцієнта жорсткості за глибиною (п. 1.1.3), причому епюра має вигнутий обрис, при якому основа вже у поверхні має значну величину коефіцієнта жорсткості. Порівняння епюр показує досить гарний збіг цих даних. Практичний метод розрахунку істотно краще описує реальну роботу палі. Моменти отримані за пропонованим методом перевершують експериментальні дані на 10\%, а за нормативним - на 50\%.

Слід зазначити також, що нормативна методика розрахунку горизонтально навантажених паль добре описує характер роботи системи за несучою здатністю і по деформативності, тільки при переміщенні менш 1 см. 


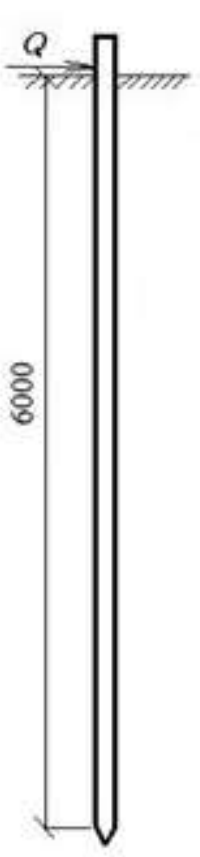

Q. TC
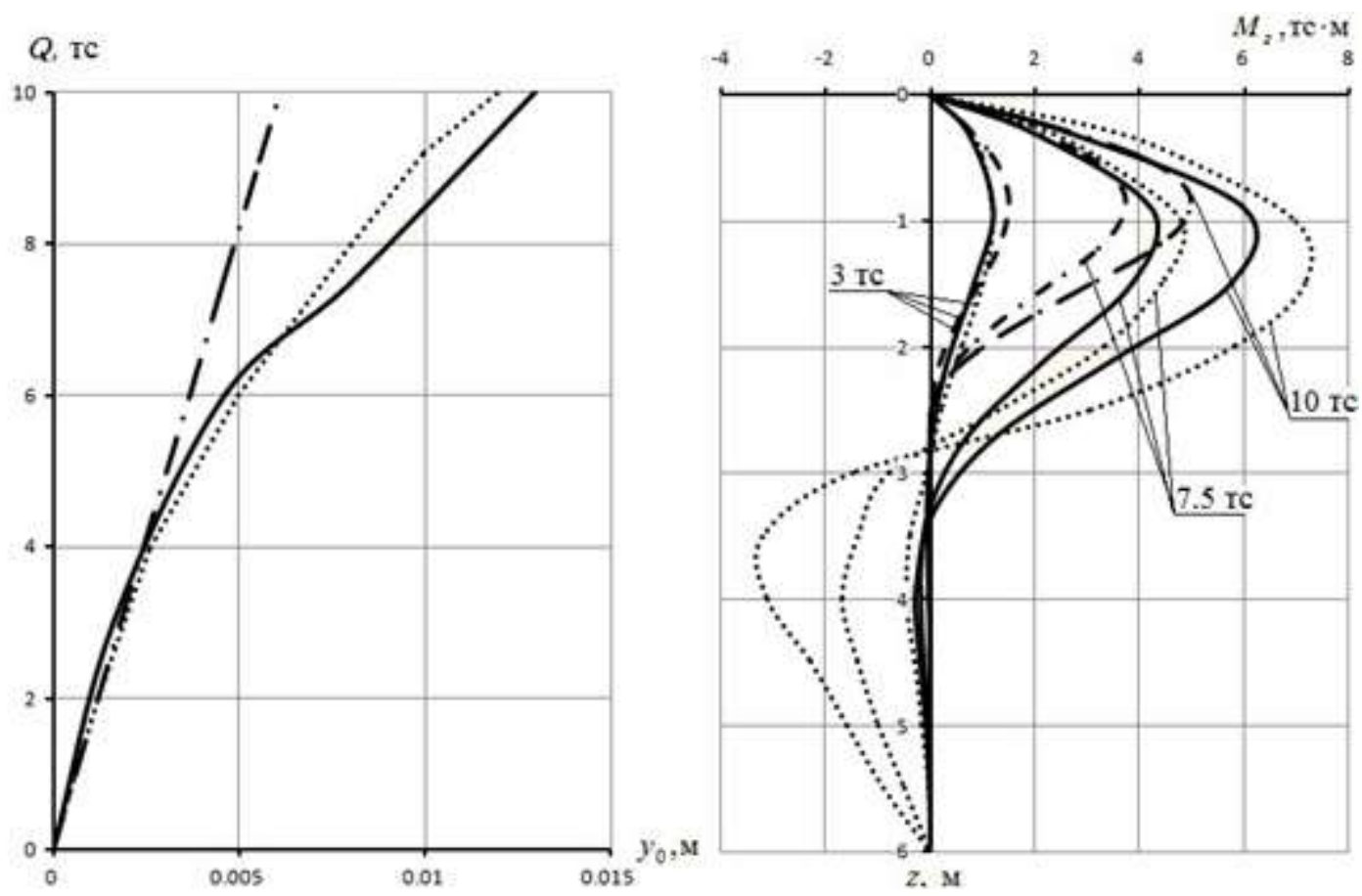

запропонована методика експеопментальні пані

- - - - нормативна методика

Малюнок 52. Порівняння теоретичних та експериментальних даних, майданчик № 2 (металеві палі).

Графіки залежності $y_{0}=f(Q)$, епюри згинальних моментів у функції від зовнішнього навантаження $\left(M_{z}=f(Q)\right)$

б) На Мал. 53 наведено епюри $y_{0}=f(Q), y_{z}=f(Q)$ i $M_{z}=f(Q)$ для металевих паль у грунті, який замочувався під час випробувань.

У разі зіставлення розрахунків зі слабким грунтом застосовувалася комплексна розрахункова модель № 3 (п. 2.1.1.3) з синусоїдальним розподілом коефіцієнта жорсткості основи по глибині, причому його епюра повинна мати увігнутий характер. Зіставлення з методикою «Керівництва» не наводимо, тому що в даному випадку повинен застосовуватися ДБН В.1.1-5-2000.

Розгляд цих графіків показує, що прийнята розрахункова модель є досить універсальною. У разі металевої, тобто пружною палі, коли нелінійність залежності $y_{0}=f(Q)$ пов'язана з непружної роботою основи, ці залежності добре описують роботу системи «паля-грунт». Розбіжність теоретичних та експериментальних горизонтальних переміщень становить не більше 15\%. Різниця в величинах згинальних моментів становить в середньому $30 \%$. 

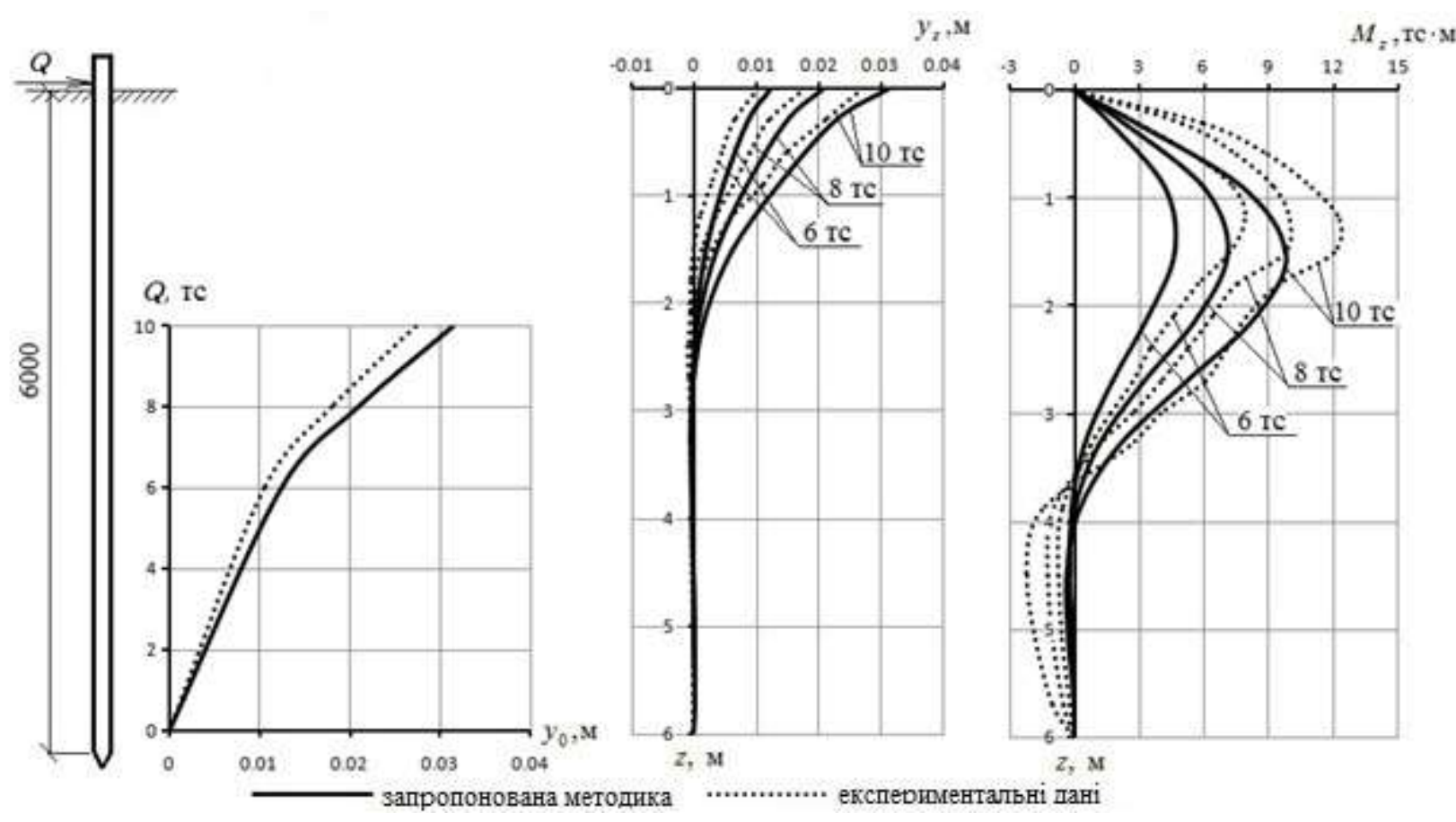

Малюнок 53. Порівняння теоретичних та експериментальних даних, майданчик № 2 (металеві палі).

Графіки залежності $y_{0}=f(Q)$, епюри горизонтальних переміщень і згинальних моментів у функції від зовнішнього навантаження $\left(y_{z}=f(Q)\right.$, $\left.M_{z}=f(Q)\right)$ 